Title Critical Success Factors for Implementing Traceability Systems in Chinese Food Enterprises

Name Meiyin Miao

This is a digitised version of a dissertation submitted to the University of Bedfordshire.

It is available to view only.

This item is subject to copyright. 


\title{
CRITICAL SUCCESS FACTORS FOR IMPLEMENTING TRACEABILITY SYSTEMS IN CHINESE FOOD ENTERPRISES
}

MEIYIN MIAO

MSc by Research

\author{
2010 \\ UNIVERSITY OF BEDFORDSHIRE
}


CRITICAL SUCCESS FACTORS FOR IMPLEMENTING TRACEABILITY SYSTEMS IN CHINESE FOOD ENTERPRISES

by

MEIYIN MIAO

A thesis submitted for the degree of Master of Science by research of the University of Bedfordshire 


\title{
CRITICAL SUCCESS FACTORS FOR IMPLEMENTING TRACEABILITY SYSTEMS IN CHINESE FOOD ENTERPRISES
}

\author{
MEIYIN MIAO
}

\begin{abstract}
Food safety has always been the focus of worldwide attention. Chinese government has promulgated a series of initiatives, laws and regulations to implement the traceability systems since 2004. However, the implementation of traceability system (TS) in China faces many challenges which are creating major barriers to the traceability system implementation success. This research aims to identify critical success factors (CSF) for implementing TS in Chinese food enterprises. More specifically, the study attempts to develop a set of criteria of TS implementation success from theoretical and practical point of views and identify and propose a framework of critical success factors for TS implementation success. To achieve the research objectives, this research adopted both qualitative and quantitative approaches. Extensive literature review was conducted to establish initial understanding of TS implementation success and associated critical success factors. Semi-structured interviews were carried out with six managers to establish a set of TS implementation success measures in the context of Chinese food enterprises. Survey questionnaires were designed to identify the critical success factors influencing TS implementation success. Primary data were collected from 124 valid responses in China. Descriptive and factor analysis were conducted using SPSS. According to the survey, the top five critical success factors are: the authenticity of traceability information; perfect food traceability laws; perfect food traceability standards; clear objectives for traceability system implementation; policy guidance for enterprises traceability system implementation from government. The framework has six dimensions of critical success factors including: laws, regulations \& standards; government support \& guidance; consumer knowledge \& support; top management, company-wide \& vendor support;
\end{abstract}


efficient management \& communication; information quality \& system quality. Based on the exploratory factor analysis a CSF framework for implementing TS in Chinese food enterprises was proposed. The outcomes of this research will have great significance for research and management in implementing TS and offering implications for policy makers and other stakeholders in the future.

Key Words: Critical Success Factors (CSF), System Implementation Success, Traceability System (TS), Framework, Food Enterprise 


\section{ACKNOWLEDGEMENTS}

First of all, I am deeply appreciative of my supervisor Prof. Yanqing Duan. Her consistent inspiration, advice, guidance and supervision have been invaluable in the completion of this research.

Particularly, I owe many thanks to Prof. Zetian Fu, Dr Ruimei Wang, Dr Xue Liu, Dr Yongmei Bentley, Dr Qile He, Ms Dong Tian, Ms Ruowei Wang and Ms Xiaoxiao Xu, as well as all other friends, who supported me with many valuable advices and helped me a lot on my study in various ways. Their patience, earnestness and perseverance have highly inspired me to be a professional and supportive person in my future career.

Also, I am grateful to all the respondents who have given their valuable time to participate in this research and completed the questionnaires.

Finally, I wish to acknowledge the continual support and unfailing love from my parents and other family members in the course of this research. 


\section{LIST OF CONTENTS}

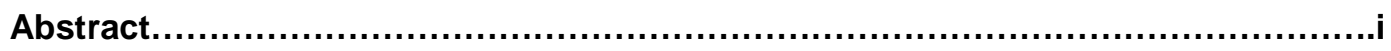

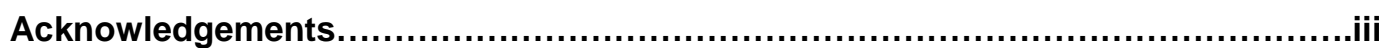

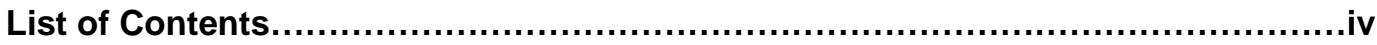

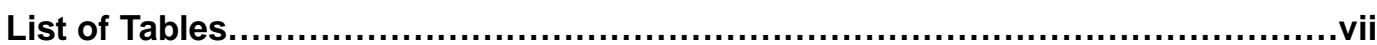

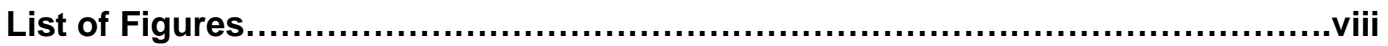

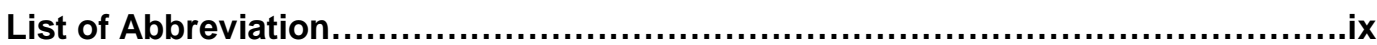

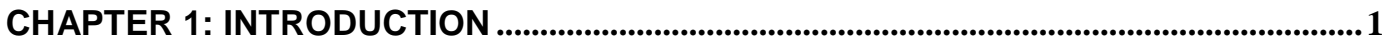

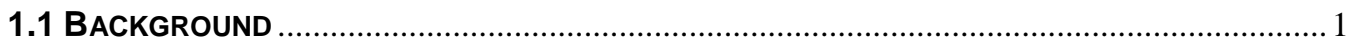

1.1.1 The Development of Implementing Food TS .............................................. 1

1.1.2 Challenges in Implementing Food Traceability System ................................. 2

1.1.3 The Significance of the Critical Success Factors............................................ 4

1.2 ReSEARCh Aim AND OBJeCtiveS .......................................................................... 5

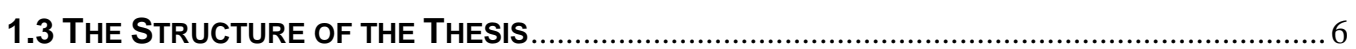

CHAPTER 2: OVERVIEW OF FOOD TS IMPLEMENTATION .............................................9

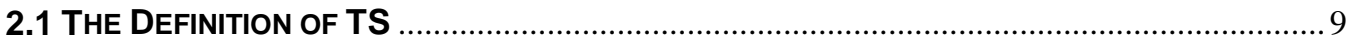

2.2 OVERVIEW OF the TS IMPLEMENTATION IN FoOd SuPply ChaIN IN DEVELOPED

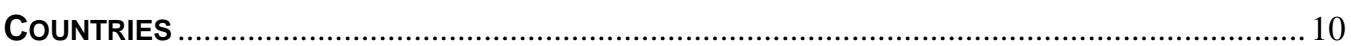

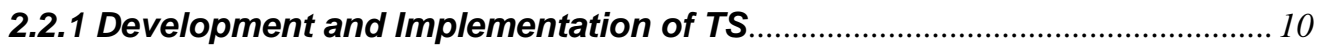

2.2.2 Legislations and Rules ...................................................................................... 12

2.2.3 Consumers' View on Food Traceability ........................................................ 16

2.3 OVERVIEW OF THE TS IMPLEMENTATION IN CHINESE FOOD ENTERPRISES ..................... 18

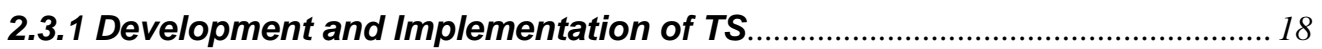

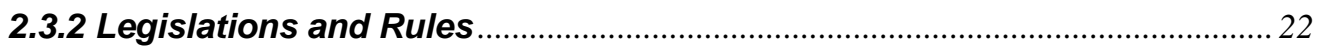

2.3.3 Challenges and Difficulties for TS Implementation...................................... 25

2.3.4 Suggestions For better Implementation of TS in China.............................. 28

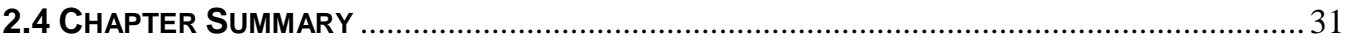

CHAPTER 3: LITERATURE REVIEW ON INFORMATION SYSTEM SUCCESS............. 32

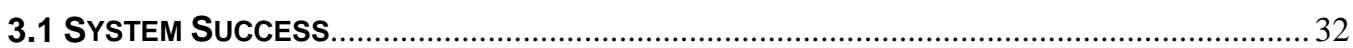

3.1.1 The Definition and Measures of System Success ..................................... 32

3.1.2 Information Systems Success Model/Framework ........................................ 33 


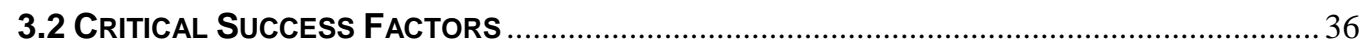

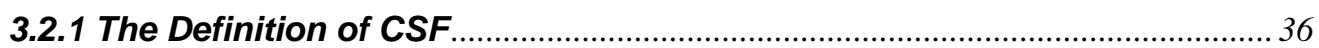

3.2.2 Methods for CSF Research.......................................................................... 37

3.2.3 CSF for Implementing Information Systems................................................ 39

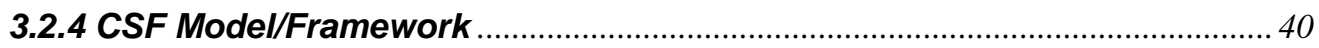

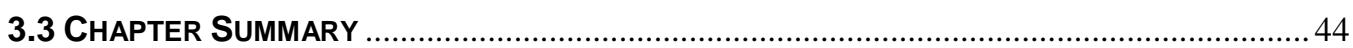

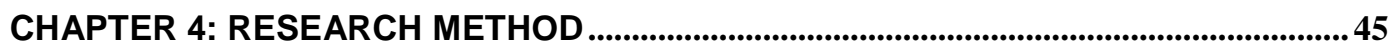

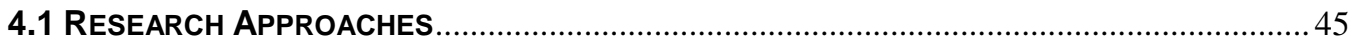

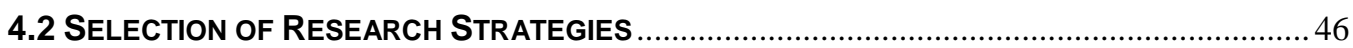

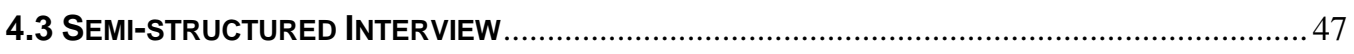

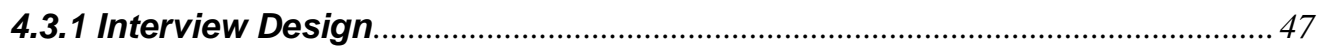

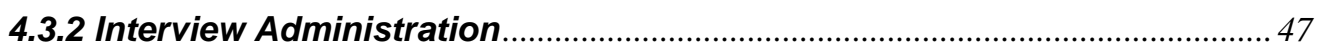

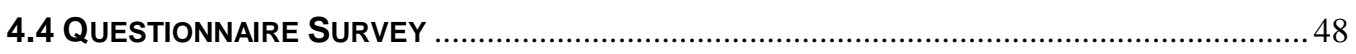

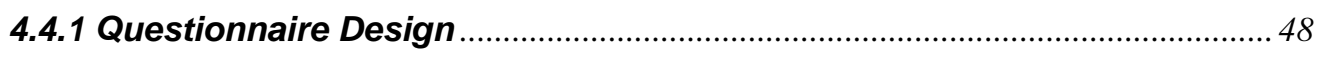

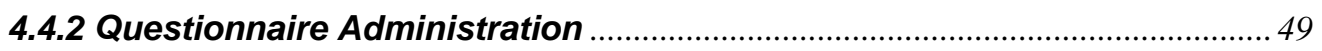

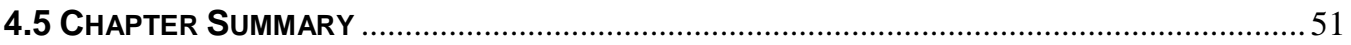

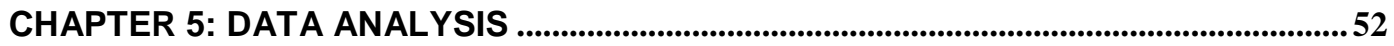

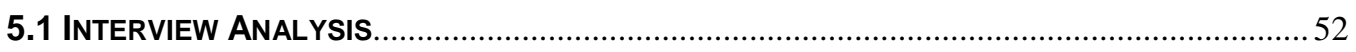

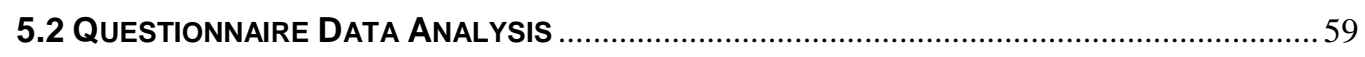

5.2.1 Analysis of Demographic Characteristics ................................................... 59

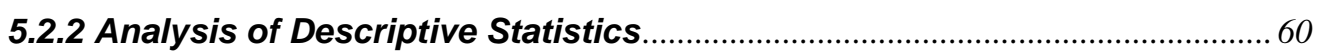

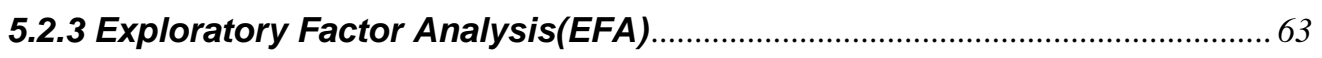

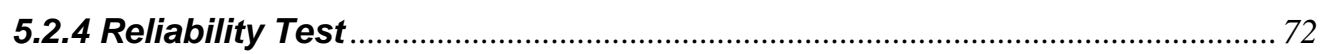

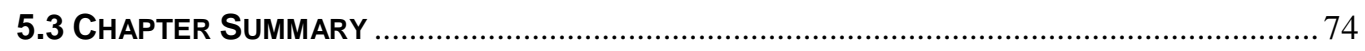

CHAPTER 6: CSF FRAMEWORK AND DISCUSSION ...................................................... 75

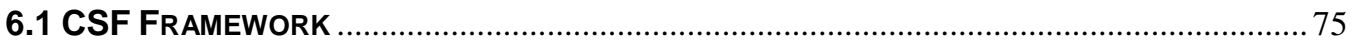

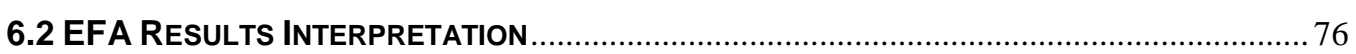

6.2.1 Laws, Regulations \& Standards ......................................................................... 76

6.2.2 Government Support \& Guidance ..................................................................... 77

6.2.3 Consumer Knowledge \& Support ...................................................................... 78

6.2.4 Top Management, Company-wide \& Vendor Support ................................... 79

6.2.5 Efficient Management \& Communication ......................................................... 80

6.2.6 Information Quality \& System Quality ............................................................ 81

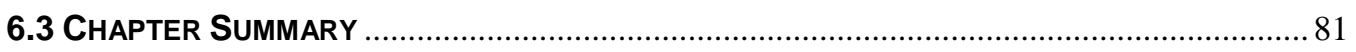

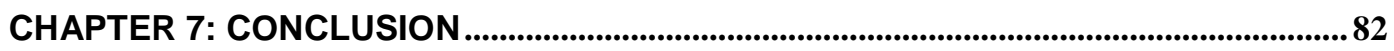

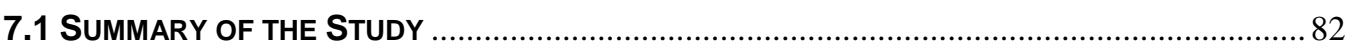

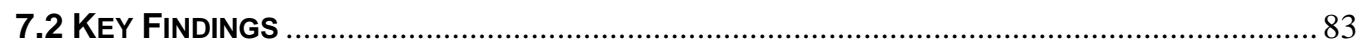

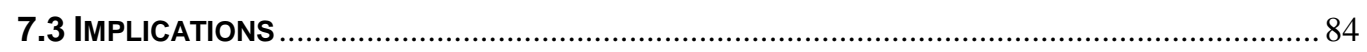

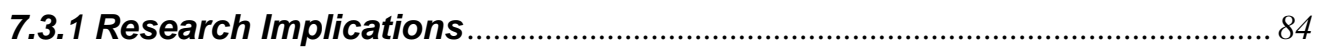

7.3.2 Implications for Business Practitioners......................................................... 85 
7.3.3 Implications for Policy Makers ................................................................... 86

7.4 RESEARCH LIMITATIONS AND FUTURE RESEARCH................................................... 87

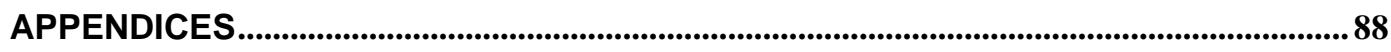

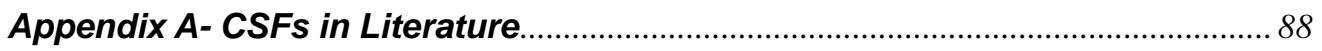

Appendix B- Participant Information Sheet (English Version)............................... 95

Appendix C- Interview Outline (English Version) ................................................. 97

Appendix D- Cover Letter (English Version)........................................................ 98

Appendix E- Questionnaire (English Version)......................................................... 99

Appendix F- Participant information sheet (Chinese Version)........................... 103

Appendix G- Interview Outline (Chinese Version)................................................ 105

Appendix H-Cover Letter (Chinese Version)....................................................... 106

Appendix I- Questionnaire (Chinese Version) .................................................... 107

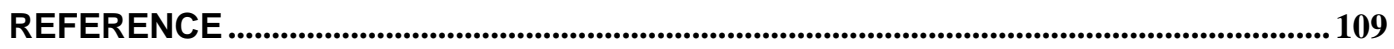

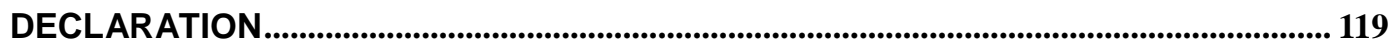




\section{LIST OF TABLES}

TABle 2.1 Provincial Distribution of TS ImPlementation In China 20

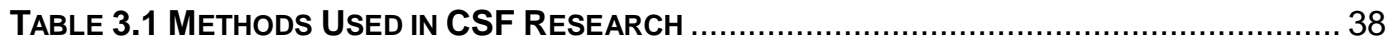

TABLE 3.2 TOP 20 CSF FOR IS IMPLEMENTATION REPORTED IN LITERATURE ..................... 39

TABle 4.1 Fundamental Differences betWeEn QUANTITATIVE AND QUALITATIVE ReSEARCH

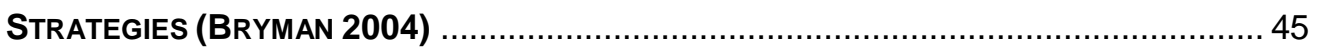

Table 4.2 the USe Frequency of Research Different Strategies ....................... 46

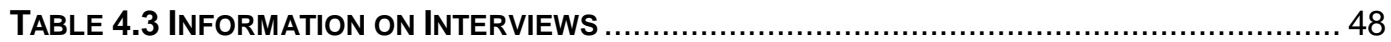

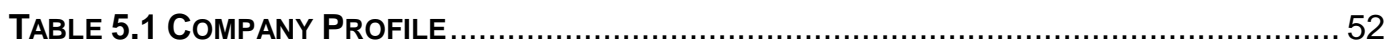

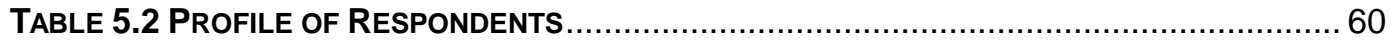

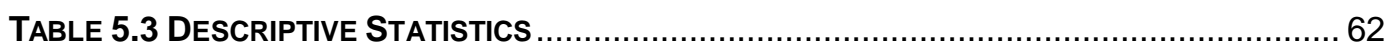

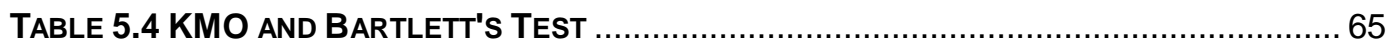

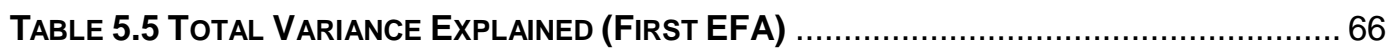

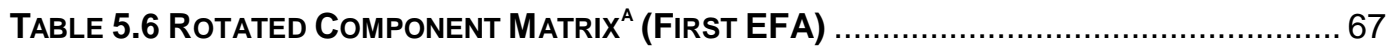

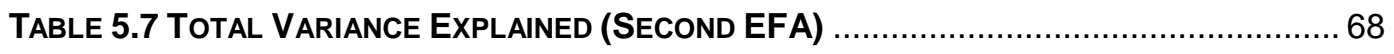

TAble 5.8 Rotated Component Matrix ${ }^{A}$ (Second EFA) ....................................... 69

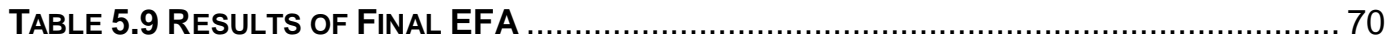

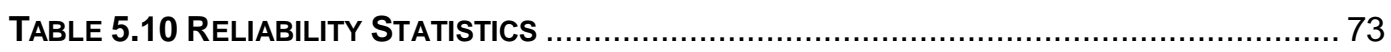




\section{LIST OF FIGURES}

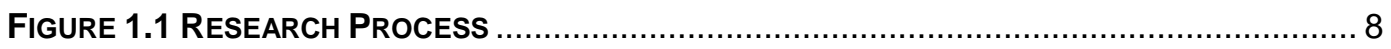

FIGURE 3.1 I/S SUCCESS Model (DELONE AND MCLEAN 1992) ......................................... 33

FiguRe 3.2 UPdated D\&M Success Model (DeLone AND MCLean 2003) ...................... 34

FiguRE 3.3 ERP SYSTEM SUCCESS FRAMEWORK (IFINEdo AND NAHAR 2006) ..................... 35

Figure 3.4 IS/IT Project Success Standard Model (Zhal et AL. 2008) ....................... 35

FiguRE 3.5 ERP SUCCESS AND CSF ConcePtUAL FRAMEWORK (ZHANG ET AL. 2005) ....... 41

FIGURE 3.6 A CSF FRAMEWORK FOR THE IMPLEMENTATION OF BUSINESS INTELLIGENCE

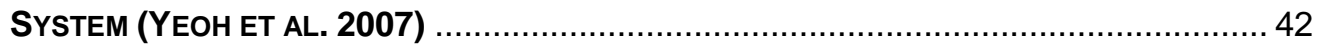

FIGURE 3.7 IS/IT PROJECT CSFS MOdEL (ZHAI ET AL. 2008) .............................................. 43

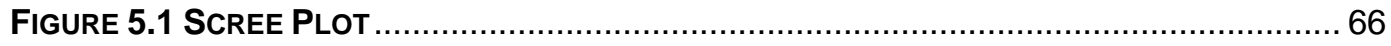

FIGURE 6.1 A CSF FRAMEWORK FOR IMPLEMENTING TS IN CHINESE FOOD ENTERPRISES .... 76 


\section{LIST OF ABBREVIATION}

$\begin{array}{ll}\text { AIDC } & \text { Automatic Identification and Data Capture } \\ \text { CAC } & \text { Codex Alimentarius Commission } \\ \text { CCSFA } & \text { China Chain Store \& Franchise Association } \\ \text { CSF } & \text { Critical Success Factor(s) } \\ \text { EAN.UCC } & \text { European Article Numbering System/Uniform Commercial Code } \\ \text { EC } & \text { European Commission } \\ \text { EEC } & \text { European Economic Community } \\ \text { EFA } & \text { Exploratory Factor Analysis } \\ \text { EU } & \text { European Union } \\ \text { FSA } & \text { Food Standard Agency } \\ \text { FSL } & \text { Food Safety Law } \\ \text { GPRS } & \text { General Packet Radio Service } \\ \text { GSM } & \text { Global System for Mobile Communications } \\ \text { HACCP } & \text { Hazard Analysis and Critical Control Point } \\ \text { IS } & \text { Information System } \\ \text { MC1R } & \text { MelanoCortin 1 Receptor } \\ \text { QSTS } & \text { Quality and Safety Traceability System } \\ \text { RFID } & \text { Radio Frequency Identification Device } \\ \text { RIA } & \text { Regulatory Impact Assessment } \\ \text { TS } & \text { Traceability System(s) }\end{array}$




\section{Chapter 1: Introduction}

\subsection{Background}

\subsubsection{The Development of Implementing Food TS}

Food safety has always been the focus of worldwide attention. The incident such as Mad Cow Disease, Foot-and-Mouth Disease in Europe, Peanut butter in the United States, Sanlu milk powder incident in China, etc., not only undermined the health and rights of consumers, but also restricted the development of food industry, as well as the impact of economic development and social stability.

Since traceability is the ability to trace the history, application or location of an entity by means of recorded information (ISO 8402:1994), the EU countries have taken the lead in applying traceability into food supply chain. The general principles and requirements of traceability and safety in food and feed especially Article 18 which contains clear requirements for traceability are established by the European Regulation (EC) No 178/2002 of 28 January 2002. Certain provisions (including Article 18) wouldn't apply until 1 January 2005 (FSA 2002). Also, the United States, Japan and other developed countries have enacted retroactive food safety-related regulations that actively promote raising the food traceability system and gradually become a new trade barrier. The basic characteristics of traceability systems are: identification of units/batches of all ingredients and products, information on when and where they are moved or transformed, a system linking these data (FSA 2002). 
In China, the term "Quality and Safety Traceability System (QSTS)" is used more popularly than "Traceability System (TS)" for that one of the important reasons for implementing TS in Chinese food enterprises is to promote quality and safety of food products. The Chinese Government recognizes the importance of food safety issues and has promulgated a series of laws and regulations (including 'The Decision of Strengthen the Food Safety' in 2004 which pointed to establish unified and standardized quality and safety standards systems and regulations of agricultural products) to implement TS or platforms to assure food safety and public health. Since the Vegetable QSTS Research and Application Demonstration Project was implemented in Shandong Province by National Barcode Project Promotion Office in June 2004, other cities such as Beijing, Shanghai have implemented TS covering vegetable, meat, fish and fishery. The systems are almost supported and implemented by government and joined by numerous agricultural, food, logistics enterprises and retailers. In June 2009, 'The People's Republic of China Food Safety Law' was performed. Then, two national standards 'General specification for food traceability' and 'Food traceability information coding and marking specifications' passed the validation in December 2009, and series of national food quality and safety standards are being developed in 2010 to enhance the food quality and safety traceability standard system being perfect.

\subsubsection{Challenges in Implementing Food Traceability System}

However, although managers in food enterprises think traceability information may have added value to the products, employees in the company believe that it "only cause more work" because of the additional time and effort made in adopting and using the technology. 
Major challenges still refer to the economic feasibleness and potential market benefits of traceability beyond legal requirements which depend on if consumers have the willingness to pay for greater access to information about the origin and history of food(Caswell 2006). Implementation of a traceability system is complicated primarily because it involves additional constraints and costs to the industry (Lavoie and Forest 2009).

Globalization of trade and the lack of international standards have made identifying the origin and history of seafood products difficult and there is still no aggregate database available to describe quantitatively the origin of the seafood in any country in the world (Sioen et al. 2007). A pan-European study by Euroconsumers showed that incorrect labeling of seafood products was the rule rather than the exception in 2006: almost $90 \%$ of the seafood samples collected from Belgian retail outlets were labeled incorrectly (Jooken and Lauryssen 2006). Also a recent Norwegian study evaluated the traceability systems in the supply chain of the Norwegian fish industry and food retail trade and showed that traceability labeling was unsatisfactory. Almost $40 \%$ of the considered fish products could not be traced back to the fishing vessel or the fish farmer(Karlsen and Senneset 2006).

The preliminary study by Food Standard Agency (FSA 2002) mentioned that a better integration of electronic data exchange is needed. However, only a few links in a supply chain are using software for internal traceability, and the diversity of the system also makes the integration difficult (Bechini et al. 2005). Implementing traceability system is preferred in large industry than small ones or rural areas. For SMEs, the technological issue is the biggest problem for implementing traceability system (Szewczyk et al. 2008). 
In China, implementing TS in food enterprises faces series difficulties and challenges. These include:

1. The complexity involved in system integration because the system should be able to collect information covering the entire supply chain (Zen 2005).

2. The difficulties in collecting large amount of information accurately and ensuring the data quality because of lower educational level of employees and lack of the sense of the responsibility of the inspector or manager (Chen 2008; Xu et al. 2008; Zhang et al. 2007).

3. Making the Information collected useful not only for consumers, but also for supporting business and management decision making by company managers(Zhang et al. 2007).

4. High cost of the implementation. Due to the lack of adequate traceability equipment in China, many companies have to use imported technologies and equipments for traceability implementation, as a result, it is expensive to implement TS (Chen 2008; Li 2006; Xu et al. 2008; Zhu 2008).

5. Inadequate national regulations and laws related to traceability (Xu et al. 2008).

These difficulties and challenges can create major barriers to the traceability system application.

\subsubsection{The Significance of the Critical Success Factors}

It is argued that to improve the implementation success of TS, it is important to identify the critical factors, so the key factors involved in TS 
implementation can be more focused and take proactive approaches. Rockart (1979) pointed out that the Critical Success Factors (CSF) “... are, for any business, the limited number of areas in which results, if they are satisfactory, will ensure successful competitive performance for the organization." They are the few key areas where "things must go right" for the business to flourish. For example, Pinto \& Slevin (1987) used the CSFs in project management and achieved successful implementation through monitoring CSFs. Williams and Ramaprasad (1998) stressed that "there is a great deal of attention devoted to the concept in the IS literature as many argue that the use of CSF can have a major impact on the design, development, and implementation of IS". Therefore, to better facilitate the TS implementation, this research aims to identify CSF for implementing TS in Chinese food enterprises. It is expected that the outcome of this research will impact on the future TS implementation success in China.

\subsection{Research Aim and Objectives}

The aim of this study is to identify critical success factors for implementing traceability systems in Chinese food enterprises.

To achieve this aim, the research will:

1. Clarify and define the key concepts in the study;

2. Develop better understanding of traceability system, system implementation success, critical success factors and other relevant theories and research through extensive literature review;

3. Establish a set of TS implementation success measures based on the literature and managers' point of view through semi-structured interviews; 
4. Identify CSF through empirical investigation using questionnaire survey;

5. Propose a CSF Framework based on literature and empirical evidence using factor analysis technique;

6. Provide valuable insights into the CSF affecting TS success and offer implications for policy makers and other stakeholders in relation to TS implementation.

\subsection{The Structure of the Thesis}

The thesis includes seven chapters: introduction, overview of food TS implementation, literature review on information system success, research method, data analysis, CSF framework and discussion, and conclusion.

Chapter 1(Introduction) gives a brief overview of the thesis. It describes the background of the topic selection, summarizes the development and challenges of implementing food TS, and states the significance of the CSF. Then, the research aim and objectives are recognized. Finally, the research process is presented in Figure 1.1.

Chapter 2 reviews the literature of food traceability system implementation. It starts with review of the definition of TS, then the TS implementation in food supply chain in developed countries and finally the TS implementation in Chinese food enterprises.

Chapter 3 reviews on information system success. It begins with the review of system success including the definition and IS success model/framework. Another section reviews the critical success factors including the definition, methods, factors summary and CSF 
model/framework.

Chapter 4 begins with describing research approaches. Next, based on the research aim, the research methods (semi-structured interview and questionnaire survey) are selected. Then, states the process of semi--structured interview. Finally, the questionnaire design and administration are introduced.

Chapter 5 starts with interview data analysis, and then the questionnaire descriptive data analysis, and finally using SPSS software for exploratory factor analysis (including reliability test etc.).

Chapter 6 proposes a CSF framework for implementing TS in Chinese food enterprises after the data analysis and discusses the CSF.

Chapter 7 begins with the summary of this study, lists the key findings of this research. Then, it gives research implications. Finally, the research limitations and future research are recommended.

Figure 1.1 shows the overall process of the research reported in the thesis. 


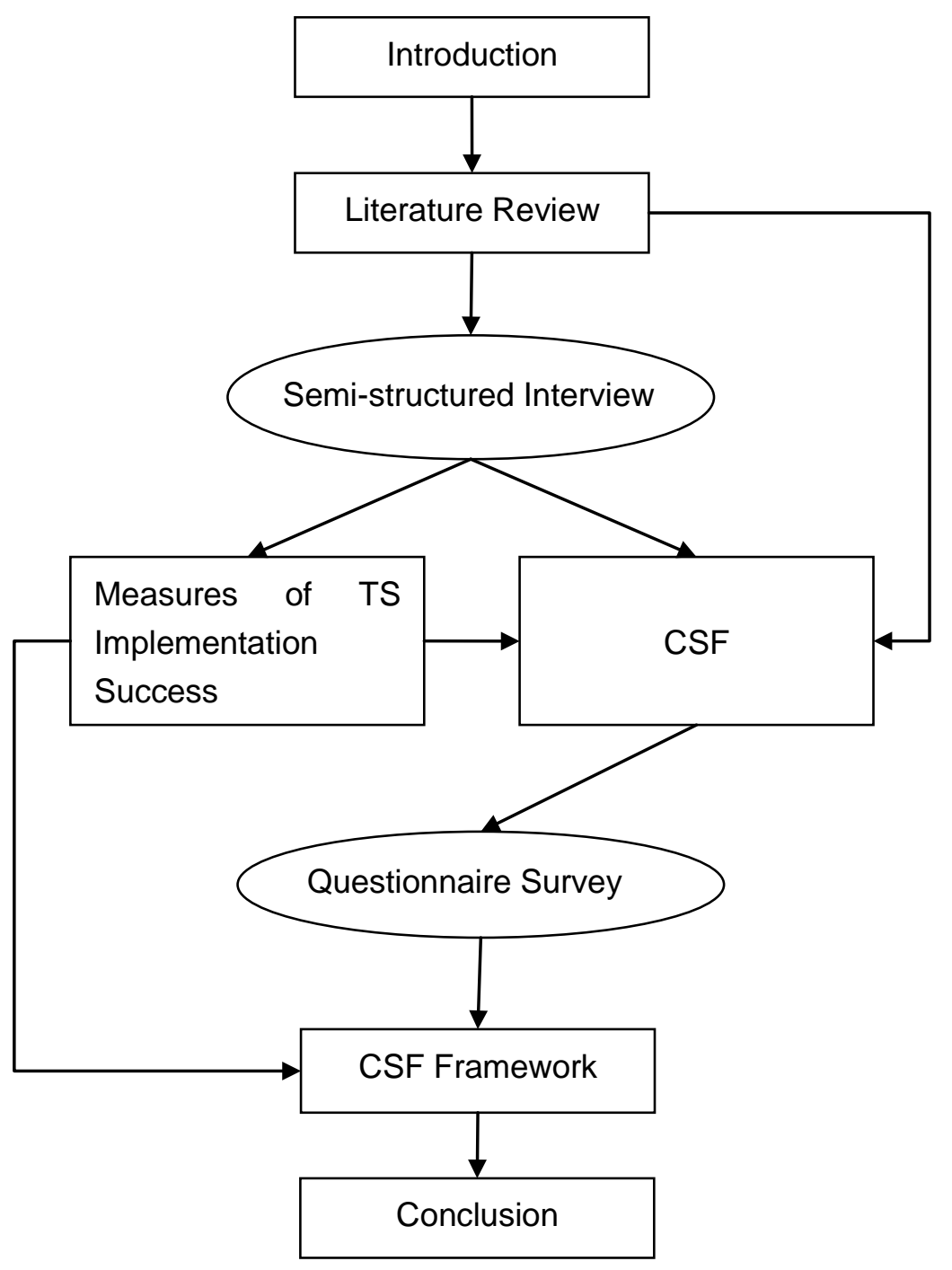

Figure 1.1 Research Process

In next two chapters, the literature will be reviewed. 


\section{Chapter 2: Overview of Food TS Implementation}

\subsection{The Definition of TS}

In 2004, Food traceability/product tracing is defined by the Codex Alimentarius Commission (CAC) as: "the ability to follow the movement of a food through specified stage(s) of production, processing and distribution". But traceability alone does not contribute to higher levels of safety or other quality attributes because it only transfers information along the supply chain (Souza-Monteiro and Caswell. 2004). When considered in isolation of other quality management systems, traceability is not sufficient. The benefits of integrating traceability into the overall quality agricultural management system are numerous, ranging from improvements in product quality and safety management, crises management in the event of a safety alert, and strengthening overall agribusiness coordination (Opara and Mazaud 2001). Traceability systems can be subdivided into four categories: country of origin; retail; processor; and farm-to-retail identity (McKean 2001).

Quality and Safety Traceability System (QSTS) is the modern information system technology and bar code technology applied in food quality and safety management. The establishment of QSTS for the entire food supply chain can identify product attributes, process attributes, environmental conditions and participant nodes attribute effectively, and preserved information record of food logistics through each node in the central database, in order to achieve top-down track of raw materials, processing, packaging, storage, transportation, and marketing in food supply chain, 
and trace from the bottom up when food safety problems occur, quickly identify problem areas and curb the proliferation of food rapidly (Lin and Zhou 2005).

For example, meat traceability refers to the ability to implement traceability in entire food supply chain including the carcasses from their place of origin, slaughtering, cutting, machining process to the end consumer, and providing consumers with accurate and detailed product information. Meat traceability system means the records system tracking a product or product feature in the entire supply chain of carcass from the breeding, slaughter and processing, packaging and marketing ( $\mathrm{Ma}$ and Wang 2006). Shao(2006) defined seafood traceability system as an information record system, i.e. recording and saving traceability information identification on the various links of the aquatic food chain during the aquatic food formation process for query when needed.

\subsection{Overview of the TS Implementation in Food Supply Chain in Developed Countries}

\subsubsection{Development and Implementation of TS}

The implementation of a national traceability system is a process comprising certain basic steps, in which the public sector must be involved since the process encompasses regulations, standards, international certification, and epidemiological considerations. Private enterprises also may participate, with their own standards and procedures (Ammendrup and Barcos 2006). As the food safety is a paramount concern for the government, many national and regional new food quality regulatory directives and laws have been issued, leaving agriculture and food 
industries in EU countries with little option but to implement traceability systems as part of the overall food safety and quality management programs.

Researchers have developed and applied a number of systems, such as genetically modified food quality traceability systems (Miraglia 2004), agricultural products supply chain quality traceability information storage system (Cimino and Lazzerini 2005), aquatic product traceability system of supply chain (Caswell 2006), meat quality traceability information system (McMeekin and Baranyi 2006) and framework of perishable food quality traceability system (Regattieri and Gamberi 2007).

Golan et al. (2004) examined traceability systems in the U.S. food supply for fresh produce, grain and oilseeds, and cattle and beef. They indicated that while complete traceability was impossible, three characteristics were important for an efficient and useful control system. These characteristics are the breadth of information (amount of collection and transmitted information), the depth of the traceability (the degree of tracing forward and backward), and the precision of the information (accuracy).

Schwagele (2005) reviewed traceability focused on meat from a European perspective from which species identification methods including protein, fatty acids and DNA-based and tracking technology including Automatic Identification and Data Capture (AIDC), European Article Numbering Association codes, Radio Frequency Identification Device (RFID), Matrix codes were analyzed and compared. Rolando and Stasio (2006) found that MC1R locus has been shown to be an effective marker in breed traceability of beef when the involved breeds were characterized by different genotypes, and moreover, compared to other genetic markers, it has the 
great advantage of not requiring DNA reference samples. DNA offers an in-built traceability verification tool that cannot be removed from a piece of meat and is not destroyed by cooking. The only criterion is as follows: for traceability to be possible, reference samples are required. For an entire meat industry, DNA offers much more than a simple traceability option by: providing information that allows genetic improvement of production animals; validating that improvement by verifying of pedigree; verifying the origin of meat; protecting the brand of niche market meats; identifying and enabling selection for meat quality detecting fraud (Shackell and Dodds 2008). Skoglund and Dejmek (2007) proposed a concept called 'fuzzy traceability' to improve the handling of batch identities in continuous production of liquid food. RFID Technology is discussed and used in food supply chain traceability (Chen et al. 2008; Kelepouris 2007; Peets et al. 2009).

The food production monitoring and traceability systems must be reliable, user-friendly and flexible for sensitive data. Data transmission is the most important part of the system. The combined modes of data transmission covered the low power radio, GSM/GPRS, Internet and satellite data transmission can be applied (Szewczyk et al. 2008). Thakur and Hurburgh (2009) proposed a framework for implementing traceability system in the bulk grain supply chain. Engelseth (2009) considered of the interplay between food product traceability and supply network integration, and proposed a conceptual model.

\subsubsection{Legislations and Rules}

There is no specific legal requirement for the implementation of traceability system in the food chain, but a number of general requirements are in 
places.

EC Commission Regulation 2065/2001 lays down detailed rules relating to consumers information and labeling for fish and fish products sold at retail. The new rules applied from 1 January 2002, although enforcement provisions in the UK were subjected to consultation until 7 May 2002. These provisions required all chilled, frozen and smoked fish or fillets and shellfish, when offered for retail sale to the final consumers to be labeled with: the commercial designation of the species; method of production (caught at sea, in inland waters or farmed) and the catch area (e.g. Pacific) or country of production if farmed. This information must be indicated on the label or posted up in the case of fresh fish sold in retail or fish monger shops etc.

Separately to measures related to food law, a revised General Product Safety Directive (2001/95/EC) which contains traceability requirements for products (including food) was adopted by the European Parliament and Council in October 2001, and member states were required to implement this with effect from January 15 2004(FSA 2002).

The EU General Food Law Regulation (178/2002) contains clear requirements for traceability, stating at Article 18:

1. The traceability of food, feed, food-producing animals, and any other substance intended to be, or expected to be, incorporated into a food or feed shall be established at all stages of production, processing and distribution.

2. Food and feed business operators shall be able to identify any person from whom they have been supplied with a food, a feed, a food-producing 
animal, or any substance intended to be, or expected to be, incorporated into a food or feed. To this end, such operators shall have in place systems and procedures which allow for this information to be made available to the competent authorities on demand.

3. Food and feed business operators shall have in place systems and procedures to identify the other businesses to which their products have been supplied. This information shall be made available to the competent authorities on demand.

4. Food or feed which is placed on the market or is likely to be placed on the market in the Community shall be adequately labeled or identified to facilitate its traceability, through relevant documentation or information in accordance with the relevant requirements of more specific provisions.

5. Provisions for the purpose of applying the requirements of this Article in respect of specific sectors may be adopted in accordance with the procedures laid down in Article 58(2).

These general traceability requirements are non-prescriptive but encompass all food and feed business operators including primary producers. Retailers of goods to the final consumer are exempt from the requirements of forward traceability. This legislation does not, however, include any requirement for records to be kept identifying how batches are split and combined within businesses to create particular products i.e. it does not require complete internal traceability. It will also not be possible to identify the bulking up of ingredients from a number of suppliers or the origin of the components of any batch.

The legislation relies on a one up, one down approach between businesses 
to create chain traceability; the robustness of such a system has not been tested. The Regulation came into force on 21 February 2002. Certain provisions (including Article 18) will not apply until 1 January 2005. This will further strengthen the legislative requirements relating to traceability by ensuring that some minimum record keeping is in place in all food businesses. The Regulatory Impact Assessment (RIA) carried out for this proposal suggested that implementation of this requirement is likely to result in minimal or no cost to businesses as most businesses will have some sort of system in place which would meet the basic requirements (FSA 2002).

In the UK, the General Product Safety Regulations (1994) includes a requirement for systems to be in place that enable product to be withdrawn from sale, where a problem that might affect consumer safety is reported. The Food Lot Marking Regulations (1996) applies to the sale of all foodstuffs for human consumption and continue to implement EC Directive 89/396/EEC, which establishes a common framework for a lot/batch identification system throughout the EU to facilitate tracing and identification of products through the food chain. The Feeding Stuffs Regulations (2000), which implement various EC directives, place controls on the marketing of feed materials (ingredients or single feeds). These require that a label must be attached to, or travel with, the batch of feed material. A compulsory beef labeling system has been required since September 2000. Information about beef, the point of slaughter the animal and approval number of the slaughtering house are reported in the label and since January 1, 2002, information on the animal's origin, in particular where the animal was born, fattened, and slaughtered have been also required in the label. Food sold to the final consumers or mass caterers, which contains GM material (i.e. protein or DNA from a genetically modified 
organism) is required to carry a label, to indicate this. The Food Irradiation Provisions (England) Regulations (2000) require that irradiation plants keep records for each batch of food irradiated. Irradiated food has to be labeled and accompanied by documentation and/or identification that identify the facility where it was irradiated.

\subsubsection{Consumers' View on Food Traceability}

Verbeke et al. (2002) researched on the topic to what extent consumer paid attention to the new compulsory EU traceability system for beef and the importance given by consumers to different mandatory indications (traceability reference number, cutting unit license number, slaughterhouse license number, etc.). Results indicated that consumers paid more attention to the other indications in the label than the traceability indications.

Verbeke and Ward (2003) studied the importance of EU label requirements to attract consumer's interest; they analyzed the indications of the mandatory European beef-labeling regulation and measured the probability of giving higher or lower scores to each of the indications. Consumers thought that the compulsory labeling of traceability system was valuable and increase their trust of the food safety although traceability alone does not contribute to higher levels of safety or other quality attributes.

Gracia and Zeballos (2005) analyzed consumer and retailer attitudes toward this system through two surveys of consumers and retailers in the province of Aragón, Spain, in 2002 and the results indicated that the majority of both consumers and retailers highly valued the positive aspects especially food safety related to the traceability and labeling system for beef, although the less people thought it led to higher beef prices or an 
unnecessary requirement because the quality and safety of beef was adequate before the implementation of the system. Verbeke and Ward (2006) determined which information cues on beef labels really attract consumers' interest from (1) indications of quality through a quality label and quality guarantee, (2) indications referring to the mandatory European beef labeling regulation and traceability system, and (3)indications reflecting country-of-origin. The results were that consumers' interest was generally low for traceability, moderate for origin, and high for direct indications of quality like a quality guarantee seal or expiration date, and also found that strategies including traceability for backing up on-label indications of quality and origin, rather than providing consumers with detailed traceability information on-label.

For example, in order to get a deeper understanding of the role of the "ability to-trace" in consumer decision- making process with respect to food and to measure consumers' acceptability for food traceability across twelve European countries, Giraud and Halawany (2006) found that participants in southern European countries (France, Italy, Malta, Slovenia and Spain) were more aware of the term 'traceability' than northern ones. In these southern European countries, traceability was considered as a buying and confidence criterion; while it did not influence participants' purchase in The Netherlands and Germany. In France, Italy, Malta, Spain, and also in Hungary and Norway, consumers related the utility of traceability to the concept of safety; while in Greece and Lithuania, it was related to quality and in Poland, it was connected to control and to withdrawal of infected batches.

Rijswijk (2008) conducted research on consumer perceptions of food quality and safety and their relation to traceability and the results indicated 
that most consumers considered food quality and food safety as interlinked concepts, and paid relatively more attention to food quality when purchasing a product. Traceability was linked not only to food safety, but also to food quality in the mind of the consumers.

In summary, the literature review indicates that the food traceability and the related traceability systems have received significant amount of research in the developed countries, such EU and USA. Consumers are well aware of the concepts of the food traceability, safety and quality and pay attention to the information provided by TS.

\subsection{Overview of the TS Implementation in Chinese Food Enterprises}

\subsubsection{Development and Implementation of TS}

In mainland China, the implementation of TS is still non-mandatory, but the implementation of TS has covered more than twenty provinces and municipalities especially in Beijing, Shanghai, Shandong, and Jiangsu et al. The majorities of systems are supported and implemented by government and joined by numerous agricultural, food, logistics enterprises and retailers.

In 2004, Vegetable Safety Traceability Information System Research and Application Demonstration Project took the lead and have been implemented in Shouguang city, Shandong province, for tracking and tracing agricultural products supply chain. This system mainly uses bar code for commodity encoding system, distribution bar code identification card to vegetable growers, encoding of vegetable processing, packaging, warehousing, transportation, selling, purchase, and consumption process 
step by step. The system ensures that all links can only identify one packaging unit of vegetables and data consistency from beginning to end to achieve total quality control (Editor 2004).

The research on TS in China mostly focuses on vegetables, aquatic products, meats and tea areas. For example, Tao (2006) discussed TS applications in vegetables, aquatic products in Beijing. Li et al.(2008) designed and implemented a web based Vegetable Traceability System which made the data update and transfer more convenient and fast. The system used two-dimensional code which has high information integration, anti-fouling capacity for code tags.

Yang (2005) integrated EAN - UCC and the HACCP system to ensure the whole supply chain traceability of eels. Yang et al. (2008b) built a Fishery Product Quality Traceability System Based on The Flow Code of Aquaculture to realize the whole process and a full range of e-management from the breeding water, aquatic breeding, seed management, feed ration to drug use, but the study focused on fresh farm products from farms directly to markets, is not related to fish processing stage. Ren et al. (2009) identified the key control points of quality and safety of tilapia breeding, and established a Web-based QSTS for Tilapia Breeding.

Xie (2005) and Xie et al (2006) used different technologies to develop Safe Pork Traceability Systems. They designed two-dimensional bar code ear tag as individual identity equipment in the breeding phase while in the slaughter phase, used RFID electronic identification and one-dimensional bar code label, to achieve automation of individual identification of pigs through the system conversion module. Yang (2007) and Yang, Luo et al. (2008a) combined farming and slaughtering areas, designed and built a 
complete Pork Traceability System. Bai et al. (2006) realized Traceable System for Broiler Safe Production Monitoring, and pointed that the integrity of traceability information chain was the key point of system functions realization. Zan et al. (2006) developed Beef quality tracking and tracing system which was in line with the actual beef production in China. China Meat Research Center and a company have jointly conducted a RFID Traceability System development and implementation which will finally achieve full tracking and tracing from the breeding, slaughtering, transporting to marketing (Zan et al. 2007). Fang and Zhao (2008) carried out a Meat Traceability System, and considered that using Iris recognition as key technology for individual animal traceability was more accurate and effective. Wu et al. (2009) introduced traceability system to tea industry.

A summary of traceability systems applications in food enterprises in China are presented in Table 2.1.

Table 2.1 Provincial Distribution of TS Implementation in China 


\begin{tabular}{|c|c|c|c|c|}
\hline Year & System & Product & Region & Source \\
\hline 2004 & $\begin{array}{l}\text { Food safety monitoring, } \\
\text { traceability, and recall public } \\
\text { service platform }\end{array}$ & $\begin{array}{l}\text { Agricultural } \\
\text { products }\end{array}$ & $\begin{array}{l}\text { Shandong, } \\
\text { Xinjiang, } \\
\text { Hainan }\end{array}$ & $\begin{array}{l}\text { http://www.safefood.gov.cn/ } \\
\text { index.html }\end{array}$ \\
\hline 2004 & $\begin{array}{l}\text { Agricultural reclamation product } \\
\text { quality traceability system }\end{array}$ & $\begin{array}{l}\text { Agricultural } \\
\text { products }\end{array}$ & $\begin{array}{l}\text { Entire } \\
\text { country }\end{array}$ & $\begin{array}{l}\text { http://www.safetyfood.gov.c } \\
\text { n/ }\end{array}$ \\
\hline 2005 & $\begin{array}{l}\text { Beef quality tracking and } \\
\text { tracing system }\end{array}$ & Beef & Shanxi & $\begin{array}{l}\text { http://jny.cq.gov.cn/detail.as } \\
\text { p?pubID=44838\&page }=23\end{array}$ \\
\hline 2007 & $\begin{array}{l}\text { Beijing Municipal Bureau of } \\
\text { Agriculture food quality and } \\
\text { safety traceability system }\end{array}$ & $\begin{array}{l}\text { Agricultural } \\
\text { products }\end{array}$ & $\begin{array}{l}\text { Beijing, } \\
\text { Hebei }\end{array}$ & http://www.atrace.org/ \\
\hline 2007 & $\begin{array}{l}\text { Chinese beef quality and safety } \\
\text { traceability system }\end{array}$ & Beef & $\begin{array}{l}\text { Liaoning, } \\
\text { Beijing, } \\
\text { Heilongjian } \\
\text { g, Inner } \\
\text { Mongolia }\end{array}$ & http://www.safebeef.cn/ \\
\hline 2007 & $\begin{array}{l}\text { Shanghai agricultural products } \\
\text { circulation safety information } \\
\text { traceability system }\end{array}$ & $\begin{array}{l}\text { Agricultural } \\
\text { products }\end{array}$ & Shanghai & $\begin{array}{l}\text { http://www.shian.gov.cn/we } \\
\text { b/Tracklnfo/trace.aspx }\end{array}$ \\
\hline 2007 & $\begin{array}{l}\text { Food safety tracking and } \\
\text { tracing system }\end{array}$ & Food & $\begin{array}{l}\text { Jiangsu } \\
\text { (Yangzhou) }\end{array}$ & $\begin{array}{l}\text { http://www.tech-food.com/ne } \\
\text { ws/2007-6-14/n0118202.htm }\end{array}$ \\
\hline 2007 & Food traceability system & $\begin{array}{l}\text { Agricultural } \\
\text { products }\end{array}$ & $\begin{array}{l}\text { Jiangsu } \\
\text { (Nanjing) }\end{array}$ & $\begin{array}{l}\text { http://www.086ny.com/Artic } \\
\text { le/2007/200703/5342.html }\end{array}$ \\
\hline 2007 & $\begin{array}{l}\text { Pork quality and safety on-line } \\
\text { traceability system }\end{array}$ & Pork & $\begin{array}{l}\text { Jiangsu } \\
\text { (Nantong) }\end{array}$ & $\begin{array}{l}\text { http://cif.mofcom.gov.cn/cif/ } \\
\text { html/sehng/2007/12/11969 } \\
\text { 10889472.html }\end{array}$ \\
\hline 2007 & $\begin{array}{l}\text { Suzhou Vegetable Association } \\
\text { agricultural products } \\
\text { (vegetables) quality and safety } \\
\text { traceability system }\end{array}$ & Vegetables & $\begin{array}{l}\text { Jiangsu } \\
\text { (Suzhou) }\end{array}$ & http://www.szscxh.org/ \\
\hline 2007 & $\begin{array}{l}\text { Xinjiang food safety traceability } \\
\text { information system }\end{array}$ & Fruits & Xinjiang & $\begin{array}{l}\text { http://www.xjfoodsafe.com.cn } \\
\text { / }\end{array}$ \\
\hline 2007 & $\begin{array}{l}\text { Vegetable quality and safety } \\
\text { traceability information system }\end{array}$ & Vegetables & $\begin{array}{l}\text { Guangxi } \\
\text { (Nanning) }\end{array}$ & $\begin{array}{l}\text { http://news.sohu.com/2007 } \\
\text { 1027/n252897843.shtml }\end{array}$ \\
\hline 2007 & $\begin{array}{l}\text { Fugang company quality and } \\
\text { safety traceability system }\end{array}$ & Apples & $\begin{array}{l}\text { Hebei } \\
\text { (Xintai) }\end{array}$ & $\begin{array}{l}\text { http://www.hebly.gov.cn/sho } \\
\text { warticle.php?id=7395 }\end{array}$ \\
\hline 2007 & $\begin{array}{l}\text { Agricultural product quality } \\
\text { Electronic traceability system }\end{array}$ & $\begin{array}{l}\text { Agricultural } \\
\text { products }\end{array}$ & Tianjin & $\begin{array}{l}\text { http://www.022net.com/200 } \\
\text { 7/11-20/434734303290397. } \\
\text { html }\end{array}$ \\
\hline 2008 & $\begin{array}{l}\text { Agricultural product quality and } \\
\text { safety traceability platform }\end{array}$ & $\begin{array}{l}\text { Agricultural } \\
\text { products to } \\
\text { Beijing }\end{array}$ & $\begin{array}{l}\text { Entire } \\
\text { country }\end{array}$ & http://www.za2008.org/ \\
\hline \multicolumn{5}{|c|}{ Continued } \\
\hline Year & System & Product & Region & Source \\
\hline
\end{tabular}




\begin{tabular}{|c|c|c|c|c|}
\hline 2008 & $\begin{array}{l}\text { Pork quality and safety } \\
\text { traceability system }\end{array}$ & Pork & Tianjin & $\begin{array}{l}\text { http://info.funbuy.cn/20083/ } \\
\text { 20/13485956156.shtml }\end{array}$ \\
\hline 2008 & $\begin{array}{l}\text { Tropical fruit quality traceability } \\
\text { system }\end{array}$ & Fruits & Hainan & $\begin{array}{l}\text { http://www.hainan.gov.cn/d } \\
\text { ata/news/2009/02/69841/ }\end{array}$ \\
\hline 2008 & $\begin{array}{l}\text { Aquatic products quality } \\
\text { traceability system }\end{array}$ & $\begin{array}{l}\text { Aquatic } \\
\text { products }\end{array}$ & Hainan & $\begin{array}{l}\text { http://orac.hainan.gov.cn/scz } \\
\text { s/newsview/NewsView.aspx? } \\
\text { ID=32 }\end{array}$ \\
\hline 2008 & $\begin{array}{l}\text { Tea product quality and safety } \\
\text { information traceability system }\end{array}$ & Tea & Sichuan & $\begin{array}{l}\text { http://www.rfidchina.org/re } \\
\text { adinfos-35225-179.html }\end{array}$ \\
\hline 2008 & $\begin{array}{l}\text { Export product quality and } \\
\text { safety traceability system }\end{array}$ & $\begin{array}{l}\text { Exporting } \\
\text { Aquatic } \\
\text { products }\end{array}$ & Fujian & $\begin{array}{l}\text { http://finance1.jrj.com.cn/n } \\
\text { ews/2008-06-06/000003731 } \\
\text { 026.html }\end{array}$ \\
\hline 2008 & $\begin{array}{l}\text { Pork quality and safety } \\
\text { traceability system }\end{array}$ & Pork & Yunnan & $\begin{array}{l}\text { http://www.jcqzw.com/newsIn } \\
\text { fo.aspx?pkld=5981 }\end{array}$ \\
\hline 2008 & $\begin{array}{l}\text { Vegetable safety traceability } \\
\text { system }\end{array}$ & Vegetables & $\begin{array}{l}\text { Inner } \\
\text { Mongolia }\end{array}$ & $\begin{array}{l}\text { http://www.cnr.cn/nmgfw/x } \\
\text { wzx/jjnmg/200809/t200809 } \\
10505096710 . h t m l\end{array}$ \\
\hline 2008 & $\begin{array}{l}\text { Harbin vegetable quality and } \\
\text { safety monitoring traceability } \\
\text { system }\end{array}$ & Vegetables & $\begin{array}{l}\text { Heilongjian } \\
\mathrm{g}\end{array}$ & $\begin{array}{l}\text { http://www.harbin.gov.cn/hr } \\
\text { bzfw/hrb_xwfb/display.php?i } \\
d=260\end{array}$ \\
\hline 2008 & $\begin{array}{l}\text { Taiyuan agricultural product } \\
\text { quality and safety traceability } \\
\text { system }\end{array}$ & $\begin{array}{l}\text { Agricultural } \\
\text { products }\end{array}$ & $\begin{array}{l}\text { Shanxi } \\
\text { (Taiyuan) }\end{array}$ & http://www.tyny.gov.cn:81/ \\
\hline 2009 & $\begin{array}{l}\text { Vegetable quality and safety } \\
\text { traceability system }\end{array}$ & Vegetables & Guangdong & $\begin{array}{l}\text { http://sz.xywy.com/html/zix } \\
\text { undaodu/20090202/121.htm }\end{array}$ \\
\hline 2009 & $\begin{array}{l}\text { Chengdu agricultural product } \\
\text { quality and safety traceability } \\
\text { public service platform }\end{array}$ & $\begin{array}{l}\text { Agricultural } \\
\text { products }\end{array}$ & $\begin{array}{l}\text { Sichuan } \\
\text { (Chengdu) }\end{array}$ & $\begin{array}{l}\text { http://www.pzhs.gov.cn/smp } \\
\text { d/clz/251071.shtml }\end{array}$ \\
\hline 2009 & Food safety traceability system & $\begin{array}{l}\text { Agricultural } \\
\text { products }\end{array}$ & Chongqing & $\begin{array}{l}\text { http://www.gov.cn/gzdt/200 } \\
\text { 9-05/25/content_1323824.ht }\end{array}$ \\
\hline 2009 & Food quality traceability system & $\begin{array}{l}\text { Fruits } \\
\text { Vegetables } \\
\text { Pork }\end{array}$ & $\begin{array}{l}\text { Zhejiang } \\
\text { (Ningbo) }\end{array}$ & $\begin{array}{l}\text { http://press.idoican.com.cn/ } \\
\text { detail/articles/20090727551 } \\
\text { A312/ }\end{array}$ \\
\hline 2009 & $\begin{array}{l}\text { Food traceability system(on } \\
\text { trial) }\end{array}$ & $\begin{array}{l}\text { Agricultural } \\
\text { products }\end{array}$ & $\begin{array}{l}\text { Hubei } \\
\text { (Wuhan) }\end{array}$ & $\begin{array}{l}\text { http://bj.house.sina.com.cn/ } \\
\text { biz/news/2009-07-31/10005 } \\
\text { 893.html }\end{array}$ \\
\hline 2009 & $\begin{array}{l}\text { Jiangxi Tea Association product } \\
\text { traceability system }\end{array}$ & Tea & Jiangxi & $\begin{array}{l}\text { http://jxcy.jxagri.gov.cn/jx/Q } \\
\text { JYY web/xiaovan.asp }\end{array}$ \\
\hline 2010 & $\begin{array}{l}\text { Meat quality and safety } \\
\text { information traceability system }\end{array}$ & Pork & $\begin{array}{l}\text { Jiangsu } \\
\text { (Wuxi) }\end{array}$ & $\begin{array}{l}\text { http://news.sohu.com/2010 } \\
\text { 0202/n270002931.shtml }\end{array}$ \\
\hline 2010 & $\begin{array}{l}\text { Meat quality information } \\
\text { traceability system }\end{array}$ & Pork & $\begin{array}{l}\text { Jiangsu(Ya } \\
\text { ngzhou) }\end{array}$ & $\begin{array}{l}\text { http://www.jiangsu.gov.cn/sh } \\
\text { ouye/zfjd/sypjg/201004/t2010 } \\
\text { 0423_444753.html }\end{array}$ \\
\hline
\end{tabular}

\subsubsection{Legislations and Rules}

General Administration of Quality Supervision, Inspection and Quarantine 
of the People's Republic of China (AQSIQ) issued "Exit Aquatic Product Traceability Procedure (On Trial) (EAPTP(OT))" and "Exit Quarantine Inspection And Aquatic Breeding Regulatory Requirements (On Trial)" in 2004, and launched from June 17th in that year. Export aquatic products producing, processing, storage enterprises need to register with health. Export aquatic products and its raw materials are required identifying in accordance with the EAPTP (OT). When there is a substandard product, the traceability of every aspect from the finished product to raw materials can come true through the product identification code. Sea capture materials can be traced back to the ship, farming materials can be traced back to farms, freshwater capture materials can be traced back to capture areas and imported raw materials can be traced back to import batches (Xiao 2004).

In July 1, 2008, "Code on Quality and Safety Control of Fishery Products for Export (GB/Z21702-2008)" issued by AQSIQ was implemented which included the document of "Exporting Aquatic Product Traceability Procedure (EAPTP)". EAPTP specifies that the export aquatic products enterprises need to have traceability information on batch determination, identification code determination, identification code management, processing requirements of different batches, documentation requirements. These enterprises should implement the traceability of export aquatic products. When there is a substandard product, it must trace the product from finished product to raw materials one by one through product identification code.

In February 28, 2009, Food Safety Law (FSL) of The People's Republic of China was passed and came into force in June 1, 2009. FSL put forward the legal requirements of establishing information record for supply chain 
including food producing, processing, packaging, procurement and so on in order to trace and recall in the future. According to FSL, in order to practice FSL and to strengthen co-ordination of food safety work, the State Council decided to establish a Food Safety Commission as a high-level counsel and coordination institution for the State Council's food safety work in February 6, 2010.

In December 2009, two food traceability national standards were passed, one is "General Specification for Food Traceability", and the other is "Food Traceability Information Encoded and Identification Specification". The former stipulated basic principles and requirements of food traceability, traceability procedure and management rules, which was suitable for all kinds food traceability systems establishment and management while the latter stipulated information code, data structure and carrier logo of food traceability, which was used in food traceability systems establishment and application.

Then, two national standards, "Agricultural Products Traceability Requirement- Honey" and "Agricultural Products Traceability RequirementTealeaves" were passed on March 1, 2010. "Agricultural Products Traceability Requirement- Aquatic Product" and "Agricultural Products Traceability Requirement- Fruits and Vegetables" are in review.

In addition, the "Basic Requirements Of Pork Traceability System", "Agricultural Products Traceability Requirement- Dairy", "Agricultural Product Traceability Information System Design Guide", "Radio Frequency Identification (RFID) Traceability Technology Requirements of Meat And Meat Products", and other national standards will be completed this year and "General Principles And Basic Requirements Of Feed and 
food Chain Traceability System Design and Implementation", "Feed and Food Chain Traceability System Design and Implementation Guide" have been completed last year. Food quality and safety traceability standard system will be perfected in China.

\subsubsection{Challenges and Difficulties for TS Implementation}

Despite the development of series standards, regulations and laws on food traceability, quality and safety, TS implementation still faces a number of serious challenges. These challenges are mainly in the following eight areas:

- Laws and regulations and standards for food traceability are improving (see Section 2.3.2), but their promotion and operation remain a challenge. The current food market implements non-mandatory access system, so the food enterprises which have established TS will take responsibility if they have unsafe product, but the firm which hasn't established a TS may avoid responsibility(Zhao and Liu 2007). Moreover, the enthusiasm of enterprises which have TS may be affected, or even is no longer maintained. In addition, segment management monitoring system is not conducive to the establishment of TS.

- Government guidance and publicity are not in place. At present, the promotion of TS mainly is government-led. The government training and publicity channels cannot meet the needs of public awareness, while the positive roles of food companies for publicity and training need further developed (Zhou and Jiang 2007). An outcome of a survey on 566 consumers for their knowledge of food traceability in 2007 was that only 23 of them (4.06\%) were familiar with the food 
which can be traced back, only 92 of them (16.25\%) just know it while 205 of them (36.22\%) were not understand and 246 of them (43.46\%) never heard in the condition of no information strengthening. After explained to respondents what were traceability and traceable food, i.e. after information strengthening, there were 445 of them (78.62\%) considered the implementation of food traceability was important, 87 of them (15.37\%) with neutral attitude, and only 34 of them (6.01\%) thought it was not important (Han and Qiao 2009).

- Consumers do not have enough confidence in food safety, and have low purchase intension for traceable food. The consumers who consider implementation of TS Important do not completely agree with that traceable foods are safer. A few of them even thought the establishment of traceability system cannot prevent food safety issues. Price is the main factor affecting consumers' purchase intention for traceable food, followed by consumers' confidence in food safety, consumer income levels, consumers' knowledge of traceable food and whether consumers encountered food safety issues (Han and Qiao 2009).

- It is difficult to interface and coordinate information. TS cover five parts including the production, circulation, sales, consumer and Monitoring. Only these five areas join seamlessly can achieve traceability "hook-ups". But it is not easy to achieve "hook-ups "because of large traceability range, heavy workload and jagged traceability management levels. In addition, the food industry in China, not only the production businesses are more scattered, but also a variety of food distribution channels such as the traditional wholesale market, the markets places and modern supermarkets coexist, and the former two 
markets take a significant proportion, therefore, this situation increases the complexity of the supply chain and the difficulties of traceability implementation (CCSFA 2007; Li et al. 2008).

- Food safety control system may not be appropriate. The monitoring system for food supply chain in China is "main sectional management, species management supplement", and different departments such as agriculture, quality inspection, industry and commerce, and health are responsible for different aspects. This kind of system which has diversify monitoring main body makes regulatory authority explicit, but also leads to the system no smooth, the lack of coordination and interaction between departments and affect the efficiency of monitoring. Decentralized monitoring power is difficult to form a systematic monitoring for food supply chain, that cannot promote the implementation of TS effectively (CCSFA 2007).

- It is difficult to collect information and to determine reliability and accuracy of the information collected. Information is the foundation and core of traceability system. Information collection is critical for system implementation. The current food enterprises, especially a lot of agricultural enterprises use "enterprise + peasant household" model and these enterprises have low level of production intensification, large traceability range and heavy workload; Information records are likely not in accordance with national standards and specifications; Different officers in charge have different levels of monitoring and management; Some employees are in low education who are difficult to understand new knowledge and to use high-tech equipment. Furthermore, the public also doubt the authenticity of the information for corporate integrity issues (Chen 2008; Li 2006; Zhang et al. 2007; Zhang and Wei 
2009).

- Independent research and development of Traceability systems are weak. Food traceability system research and implementation are in the initial stage in China. Results of core technologies with proprietary intellectual property rights are few. Most of the existing technologies, and supporting tech equipments draw on foreign or imported (Li 2006; Zhang et al. 2007).

- The cost of implementing TS in enterprises is high. Implementing systems need professional technology, equipment and personal maintenance which add the cost. At present, most food enterprises are small or medium, and their own resources and financial strength are limited, although obtain the state investment still far from adequate (Chen 2008; Xu et al. 2008; Zhu 2008).

In summary, challenges and difficulties which traceability systems implementation face are from various stakeholders involved, such as government (e.g. weak operation of laws, regulations and standards, weak publicity of traceability), consumers (e.g. lack of confidence in food safety, low purchase intension for traceable food), and the traceability systems themselves (e.g. the reliability and accuracy of information collected, weak independent research and development of traceability systems). Although the challenges and difficulties in TS implementations are well acknowledged and discussed in the literature, they are not supported with sound empirical evidence.

\subsubsection{Suggestions For better Implementation of TS in China}

Having reviewed the traceability systems implementation in the West and 
China, the following suggestions can be highlighted based on the information collected:

- Improve laws, regulations and standards (Yin et al. 2008; Zan et al. 2007). Although China has promulgated FSL and other laws, regulations and standards like "General Specification for Food Traceability" and "Food Traceability Information Encoded and Identification Specification" et al., but still need to continue to refine the standards and to promote to enterprises.

- Increase policy guide and funding to TS implementation from government. Although the government and industry recognized food traceability, the most concerned by enterprises are costs and risks, including the TS development, application, maintenance, management and many other costs. Enterprises also consider whether implementation of system is truly effective, whether revenue can compensate spending, and whether enterprises get the benefits from other areas besides improving the efficiency of food traceability, etc. (Lin and Zhou 2005). Therefore, in the condition of initial stage of applying food traceability in China, the government should increase preferential policies and subsidies to enterprises which apply food traceability (CCSFA 2007; Zan et al. 2007; Zhang and Wei 2009).

- Government and enterprises need disseminate knowledge of food traceability intensively. Letting people know traceability can track and monitor the occurrence of food safety issues, stimulate consumer demand of traceable products to establish the social basis for the implementation of traceability. Meanwhile, through publicity, food companies can recognize using TS are able to monitor their products 
effectively, reduce the quality risk, improve product image and enhance market competitiveness (CCSFA 2007; Xu and Wu 2008; Zhou and Jiang 2007).

- Straighten food safety monitoring system. Only coordinating the responsibilities of each departments, and building relatively centralized and unified professional monitoring system, to achieve the unify monitoring of the food supply chain can form the traceability of full supply chain(CCSFA 2007). Establishing a national authority institution which is responsible for the management of TS and unifying action will enhance the efficiency of food traceability and food safety in China (Yin et al. 2008).

- Increase training and education efforts, and enhance enterprises responsibility and integrity. Traceability system involving advanced technology and high-tech equipment, while a considerable number of employees at the grassroots level didn't get good education when they are young, so it must increase the training and education, improve the quality of all employees, strengthen the sense of responsibility, and ensure the correct operation and uploading authentic information (Han and Qiao 2009; Zhang and Wei 2009).

- Enhance technological research of traceability to provide independent development and more practical technology. Cost is one of the major factors for setting back widely use of traceability system. Thus, the companies and institutions who offer traceability technology need develop more convenient, lower cost technologies and equipments (CCSFA 2007)which can integrate with world (Xu et al. 2008) and also suitable for China national conditions (Zhang and Wei 2009). 
- Select corporate champion to develop food TS demonstration projects. TS need gradually be established. It must choose some large and mature enterprises as pilot projects before China have enough experience. After getting some experience then can promote TS for other enterprises, and demonstrate the functions traceability played in protecting food safety to use the demonstration effect for promoting traceability (CCSFA 2007; Yin et al. 2008).

In summary, the suggestions summarized are related to external environment and internal management. The external related suggestions include: improving laws, regulations and standards; increasing policy guidance and funding support; disseminating knowledge of traceability. Internal related suggestions include: increasing training and education, enhancing enterprise responsibility and improving technological research. These suggestions are useful guidelines, but they may represent limited viewpoints and are not derived from systematic studies with empirical evidence. Therefore, there is still an emerging need to provide a systematic empirical investigation to further explore and validate the potential critical success factors by collecting data from various stakeholders in the context of Chinese food enterprises.

\subsection{Chapter Summary}

This chapter reviewed the literature in three sections. The first section presented the definition of traceability system. Then, the TS Implementation in food supply chain in developed countries was overviewed in the second section, and the final section reviewed the TS Implementation in Chinese food enterprises. 


\section{Chapter 3: Literature Review on Information System Success}

The previous chapter reviewed the development of traceability systems implementation in western countries and China. The purpose of this research is to identify the critical success factors for implementing TS in Chinese food enterprises, the measures of traceability system implementation success need to be clarified first. Therefore, a comprehensive literature review on the definition and measures of system success and the research model/framework; critical success factors and research model/framework are presented in the following sections.

\subsection{System Success}

\subsubsection{The Definition and Measures of System Success}

In 1992, DeLone and McLean proposed six major categories or aspects of I/S success----System Quality, Information Quality, Information Use, User Satisfaction, Individual Impact, and Organizational Impact (see Figure 3.1) which then had been widely used in system success research by the scholars all over the world (DeLone and McLean 1992). And ten years later, DeLone and McLean(2003) updated the aspects as Information Quality, System Quality, Service Quality, Intention to Use(Use), User Satisfaction and Net benefits(see Figure 3.2).

Zhang et al.(2005) studied ERP system implementation success and they used four aspects including User satisfaction, Individual impact, 
Organizational impact, Intended business performance improvement. Yeoh et al.(2007) divided four aspects of Business Intelligence System (BIS) implementation success into two categories as Infrastructure Performance (System Quality, Information Quality) and Process Performance (Budget, Time Schedule).

The successful implementation of a Hospital's Information System (HIS) is determined by examining if the installed system satisfies the initially stated, in the planning phase, set of goals (Sarivougioukas and Vagelatos 2002). The implementation success of Internet-based Information Systems(IIS) is defined by the extent of IIS implementation, as represented by volume, sophistication, and information contents (Lee and Kim 2007). At the most basic level, success for government led foresight programs can be defined as attainment of the foresight programs goals. This suggested two dominant criteria for success - impact and survival (Calof and Smith 2008). Project success is defined as organizational impact and on time and on/under budget project completion (Bradley 2008).

\subsubsection{Information Systems Success Model/Framework}

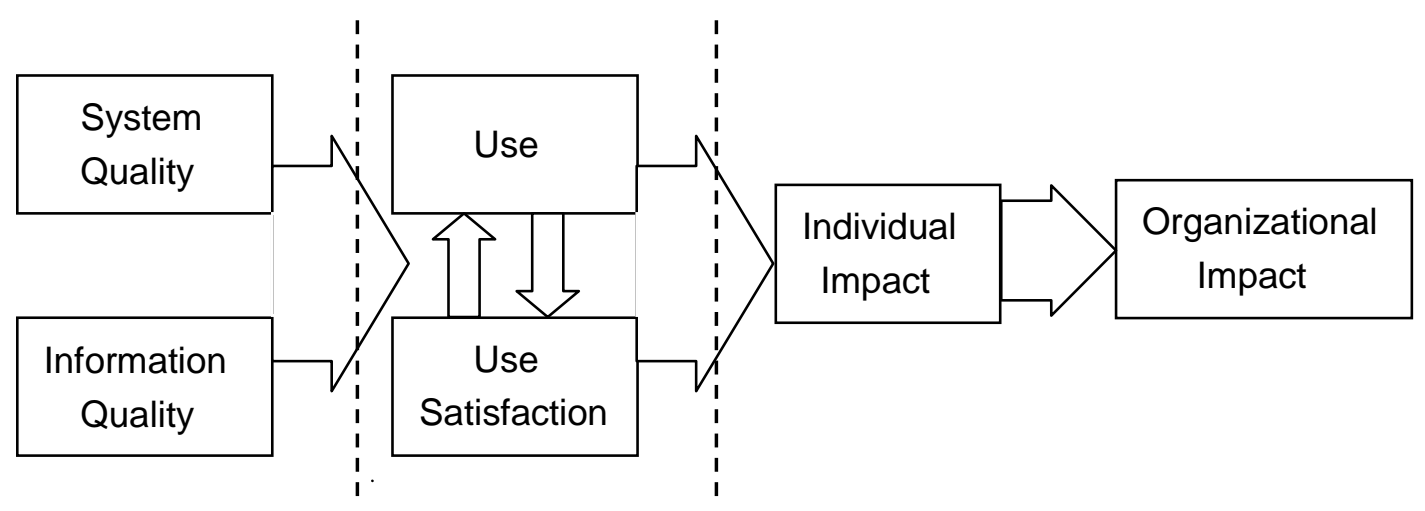

Figure 3.1 I/S Success Model (DeLone and McLean 1992) 
Grover et al. (1996) used an alternative, theoretically based perspective (theory of organizational effectiveness) "to build a theoretically-based construct space for IS effectiveness which complements and extends the [DeLone \& McLean] IS Success Model". Based on unit-of-analysis and evaluation-type context dimensions, the authors created six effectiveness categories. The six effectiveness classes are infusion measures, market measures, economic measures, usage measures, perceptual measures, and productivity measures. Their framework considers "system quality" and "information quality" to be antecedent effectiveness constructs, whereas the D\&M IS Success Model considers them to be important dimensions of success itself.

In summary, Grover et al.'s IS effectiveness framework serves to validate the D\&M IS Success Model from a theoretical perspective and suggests an area for extension, namely, market impacts.

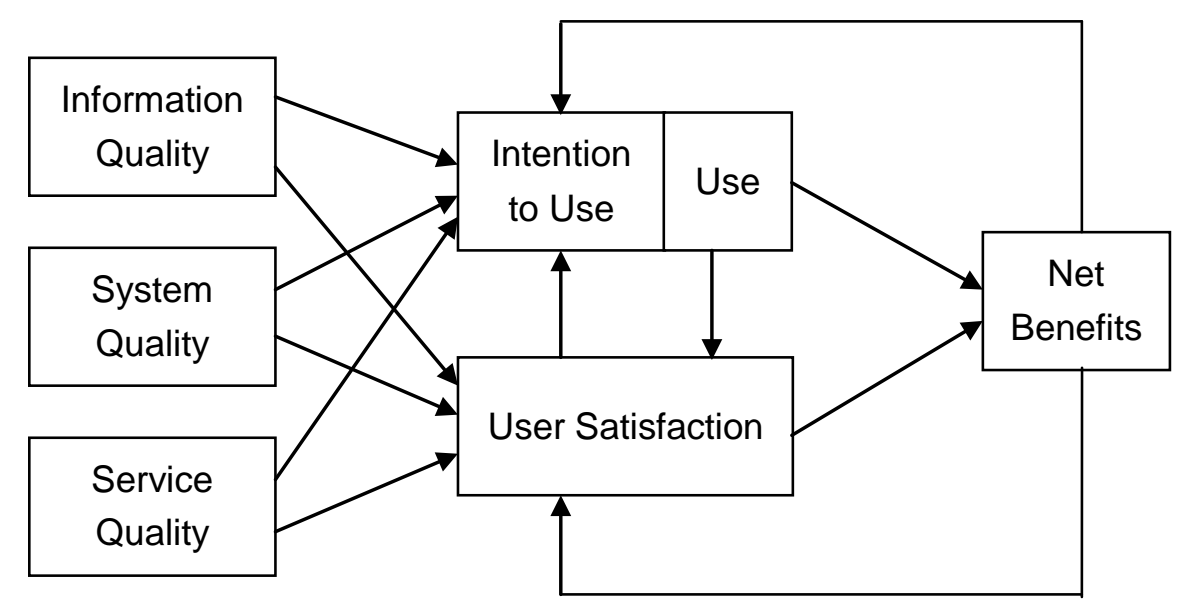

Figure 3.2 Updated D\&M Success Model (DeLone and McLean 2003)

DeLone and McLean(2003) stated that their success model has "become a standard for the specification and justification of the measurement of the dependent variable in information systems research." 
Ifinedo and Nahar (2006) propose an ERP success model which eliminated use and user satisfaction from the DeLone-McLean model, but adds vendor/consultant quality and workgroup impact (see Figure 3.3).

\begin{tabular}{|c|l|l|}
\hline System Quality & & \\
\cline { 1 - 1 } Information Quality & & ERP \\
\cline { 1 - 2 } Vendor/Consultant & & System \\
\cline { 1 - 2 } Individual Impact & & Success \\
\cline { 1 - 2 } Workgroup Impact & & \\
\hline Organizational Impact & & \\
\hline
\end{tabular}

Figure 3.3 ERP System Success Framework (Ifinedo and Nahar 2006)

Zhai et al(2008) proposed IS/IT Project Success Standard Model(see Figure 3.4).

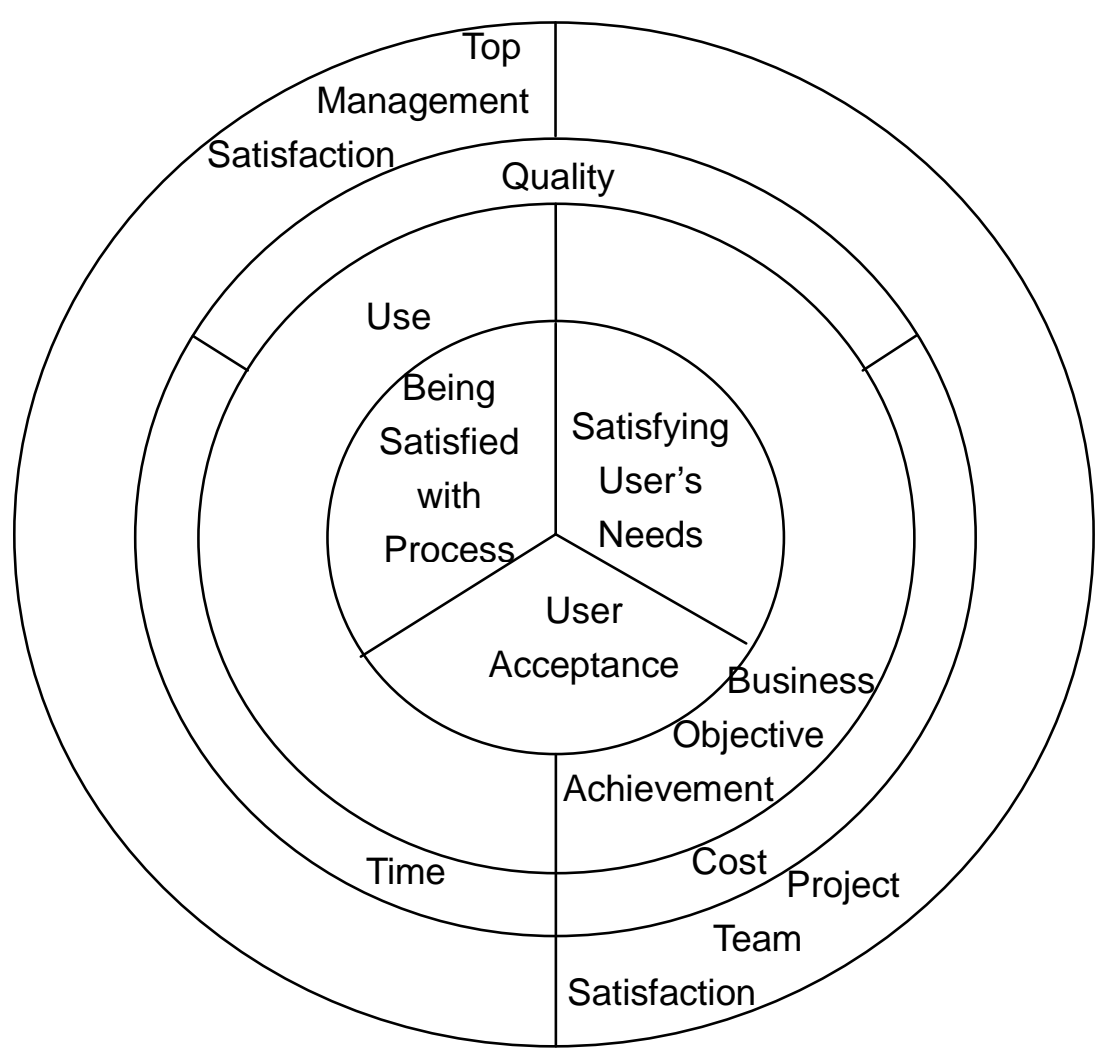

Figure 3.4 IS/IT Project Success Standard Model (Zhai et al. 2008) 
The model includes five success standard factors. Ranking according to the importance, they are user factor, project delivery after factor, iron triangle factor, top management factor, and the project team factor respectively. The core layer of the model is user standard including 'Being Satisfied with Process', 'Satisfying User's Needs', and 'User Acceptance'; the following layer is the project delivery after standard which includes 'Use' and 'Business Objective Achievement'; then the iron triangle standard including 'Quality', 'Time', and 'Cost'; and the final two standards are 'Top Management Satisfaction' and 'Project Team Satisfaction'.

\subsection{Critical Success Factors}

\subsubsection{The Definition of CSF}

Critical Success Factors (CSF) research can be traced back to Daniel (1961) who first discussed "success factors" in management literature, and pointed that the companies which have achieved greatest achievements in information analysis always focused on success factors when they developed systems. In 1972, Anthony et al. studied further by emphasizing the need to tailor CSF to both a company's particular strategic objectives and its particular managers(Anthony et al. 1972). Rockart (1979) represented the CSF "thus are, for any business, the limited number of areas in which results, if they are satisfactory, will ensure successful competitive performance for the organization. They are the few key areas where 'things must go right' for the business to flourish (p.85)." In 1982, Rockart collected data in regard to IS executives and the data indicated that executives share a limited number of CSF. The remaining differences were linked to organizational aspects as well as the time pressure facing the particular manager at the time the data was collected (Rockart 1982). 
Dickinson et al (1984) gave a comprehensive definition of CSF as "events, circumstances, conditions, or activities that require special attention because of their significance to the corporation. They can be internal or external and can influence the success of the corporation either positively or negatively (p. 24). " Leidecker and Bruno (1984) defined CSF as "those characteristics, conditions or variables that, when properly sustained, maintained, or managed, can have a significant impact on the success of a firm competing in particular industry"(p. 24).

Pinto and Slevin (1987) applied the CSF in project management and guided the successful implementation of project through monitoring CSF. Ramaprasad and Williams (1998) highlighted this position by representing that "there is a great deal of attention devoted to the concept in the IS literature as many argue that the use of CSF can have a major impact on the design, development, and implementation of IS(p. 858)." O‘Biren (2002) pointed out that the senior director thought CSF were the keys to ensure successful performance of organizations and to achieve their goals.

\subsubsection{Methods for CSF Research}

After literature review, the research methods of identifying or testing critical success factors used in literatures are summarized in Table 3.1.

Thus, the methods of theoretical build of CSF are Literature Review and Case Study which usually via interview. Empirical study methods are including Multiple-case Study, Structured Interview, Questionnaire Survey, and Delphi. Actually, analysis of critical success factors for implementing information system in enterprise is the process of comprehensive and flexible use of various methods. 
Table 3.1 Methods Used in CSF Research

\begin{tabular}{|c|c|c|c|}
\hline Method & Author & Description & \\
\hline \multirow[t]{2}{*}{$\begin{array}{l}\text { Literature } \\
\text { Review(LR) }\end{array}$} & Al-Fawaz et al.(2008) & Review CSF & $\begin{array}{l}\text { Theoretical } \\
\text { build }\end{array}$ \\
\hline & Rabaa'i (2009) & Identify factors: LR & $\begin{array}{l}\text { Theoretical } \\
\text { build }\end{array}$ \\
\hline \multirow[t]{6}{*}{$\begin{array}{l}\text { LR + Case } \\
\text { Study(CS) }\end{array}$} & Zhang et al.(2005) & $\begin{array}{l}\text { Identify factors: LR } \\
\text { Examine: Multiple CS }\end{array}$ & $\begin{array}{l}\text { Empirical } \\
\text { Study }\end{array}$ \\
\hline & Dubelaar, et al.(2005) & Identify factors: LR+ Multiple CS & $\begin{array}{l}\text { Theoretical } \\
\text { build }\end{array}$ \\
\hline & Lu et al.(2006) & Identify factors: LR+ CS(via interview) & $\begin{array}{l}\text { Theoretical } \\
\text { build }\end{array}$ \\
\hline & Nah and Delgado (2006) & $\begin{array}{l}\text { Identify factors: LR } \\
\text { Examine : Multiple CS(via structured } \\
\text { interview + questionnaire) }\end{array}$ & $\begin{array}{l}\text { Empirical } \\
\text { Study }\end{array}$ \\
\hline & Bradley (2008) & $\begin{array}{l}\text { Identify factors: LR } \\
\text { Validate : Multiple CS(via structured } \\
\text { interview(face to face/e-mail/phone)) }\end{array}$ & $\begin{array}{l}\text { Empirical } \\
\text { Study }\end{array}$ \\
\hline & Doom et al. (2010) & $\begin{array}{l}\text { Identify factors: LR } \\
\text { Validate : Multiple CS(via structured } \\
\text { interview(face to face) }\end{array}$ & $\begin{array}{l}\text { Empirical } \\
\text { Study }\end{array}$ \\
\hline \multirow{9}{*}{$\begin{array}{l}\text { LR }+ \\
\text { Questionnaire } \\
\text { Survey(QS) }\end{array}$} & $\begin{array}{l}\text { Kim and Peterson } \\
(2000 / 2001)\end{array}$ & $\begin{array}{l}\text { Identify factors: LR } \\
\text { Examine: QS(via mail) }\end{array}$ & $\begin{array}{l}\text { Empirical } \\
\text { Study }\end{array}$ \\
\hline & Zhang et al.(2002) & $\begin{array}{l}\text { Conceptual framework: LR } \\
\text { Examine: QS(via mail + internet) }\end{array}$ & $\begin{array}{l}\text { Empirical } \\
\text { Study }\end{array}$ \\
\hline & Croteau and Li (2003) & $\begin{array}{l}\text { Identify factors: LR } \\
\text { Validate: QS(via mail) }\end{array}$ & $\begin{array}{l}\text { Empirical } \\
\text { Study }\end{array}$ \\
\hline & Ngai, et al.(2004) & $\begin{array}{l}\text { Questionnaire design based LR } \\
\text { Identify factors: QS (via e-mail +fax) }\end{array}$ & $\begin{array}{l}\text { Empirical } \\
\text { Study }\end{array}$ \\
\hline & Wong (2005) & $\begin{array}{l}\text { Identify factors: LR } \\
\text { Examine: QS(via mail) }\end{array}$ & $\begin{array}{l}\text { Empirical } \\
\text { Study }\end{array}$ \\
\hline & $\begin{array}{ll}\text { García-Sánchez } & \text { and } \\
\text { Pérez-Bernal (2007) } & \\
\end{array}$ & $\begin{array}{l}\text { Identify factors: LR } \\
\text { Validate: QS(via e-mail) }\end{array}$ & $\begin{array}{l}\text { Empirical } \\
\text { Study }\end{array}$ \\
\hline & Chetcuti (2008) & $\begin{array}{l}\text { Identify factors: LR } \\
\text { Validate: QS }\end{array}$ & $\begin{array}{l}\text { Empirical } \\
\text { Study }\end{array}$ \\
\hline & Dan (2009) & $\begin{array}{l}\text { Identify factors: LR } \\
\text { Examine: QS(via mail) }\end{array}$ & $\begin{array}{l}\text { Empirical } \\
\text { Study }\end{array}$ \\
\hline & Hsu et al.(2010) & $\begin{array}{l}\text { Identify factors: LR } \\
\text { Examine: QS }\end{array}$ & $\begin{array}{l}\text { Empirical } \\
\text { Study }\end{array}$ \\
\hline \multirow[t]{2}{*}{ LR + Interview } & $\mathrm{LOH}$ and $\mathrm{KOH}(2004)$ & Identify factors: LR+ Interview & $\begin{array}{l}\text { Theoretical } \\
\text { build }\end{array}$ \\
\hline & Lee and Kim (2007) & $\begin{array}{l}\text { Identify factors: LR } \\
\text { Validate: Structured interview }\end{array}$ & $\begin{array}{l}\text { Empirical } \\
\text { Study }\end{array}$ \\
\hline $\begin{array}{l}\text { LR+Interview+ } \\
\text { QS }\end{array}$ & Bhatti (2005) & $\begin{array}{l}\text { Identify factors: LR } \\
\text { Design questionnaire: } \\
\text { LR+Interview } \\
\text { Validate: QS }\end{array}$ & $\begin{array}{l}\text { Empirical } \\
\text { Study }\end{array}$ \\
\hline LR + Delphi & Yeoh et al.(2007) & Identify factors: LR+ Delphi & $\begin{array}{l}\text { Empirical } \\
\text { Study }\end{array}$ \\
\hline
\end{tabular}




\subsubsection{CSF for Implementing Information Systems}

Numerous studies have been reported in the literature on CSF in IS implementations. Appendix A provided a detailed account of the factors identified by various researchers. Table 3.2 presented the top 20 critical success factors extracted from 42 literatures in Appendix A according to their frequencies in literature ( $\mathrm{N}=$ use frequency). These factors are important theoretical basis for this study and are considered in the survey questionnaire design.

Table 3.2 Top 20 CSF for IS Implementation Reported in Literature

\begin{tabular}{|l|c|}
\hline \multicolumn{1}{|c|}{ CSF } & N \\
\hline Top management support & 25 \\
Project management & 23 \\
(User)Training & 19 \\
Change management & 17 \\
Business process reengineering & 16 \\
Communication & 14 \\
Project champion & 13 \\
User involvement & 11 \\
Business plan and vision & 9 \\
Education & 9 \\
Testing and trouble shooting. & 7 \\
Change culture & 7 \\
Commitment by top management & 6 \\
Clear goals and objectives & 6 \\
ERP teamwork and composition & 6 \\
Vendor support & 5 \\
Careful package selection & 5 \\
Project team competence/capability & 5 \\
A great implementation team & 5 \\
Use of consultants & 5 \\
\hline
\end{tabular}

Note: detailed information on references used for producing this table is in Appendix A. 


\subsubsection{CSF Model/Framework}

One of the objectives of this study is proposing a critical success factors framework for implementing traceability systems in Chinese food enterprises. Therefore, models/frameworks of CSF in literature are reviewed in this section.

Zhang et al. (2005) proposed ERP Success and CSF Conceptual Framework(see Figure 3.5).The framework used four environment presenting 12 CSF: (1) Organizational environment factors include Top Management Support, Company-wide Support, Business Process Reengineering, Effective Project Management, and Organizational Culture; (2) User environment factors include Education \& Training, User Involvement, and User Characteristics; (3) System environment factors include ERP Software Suitability, Information Quality, and System Quality; (4) ERP environment factors include ERP Vendor Quality. The dimensions of ERP implementation success were User Satisfaction, Individual Impact, Organizational Impact, and Intended Business Performance Improvement. 


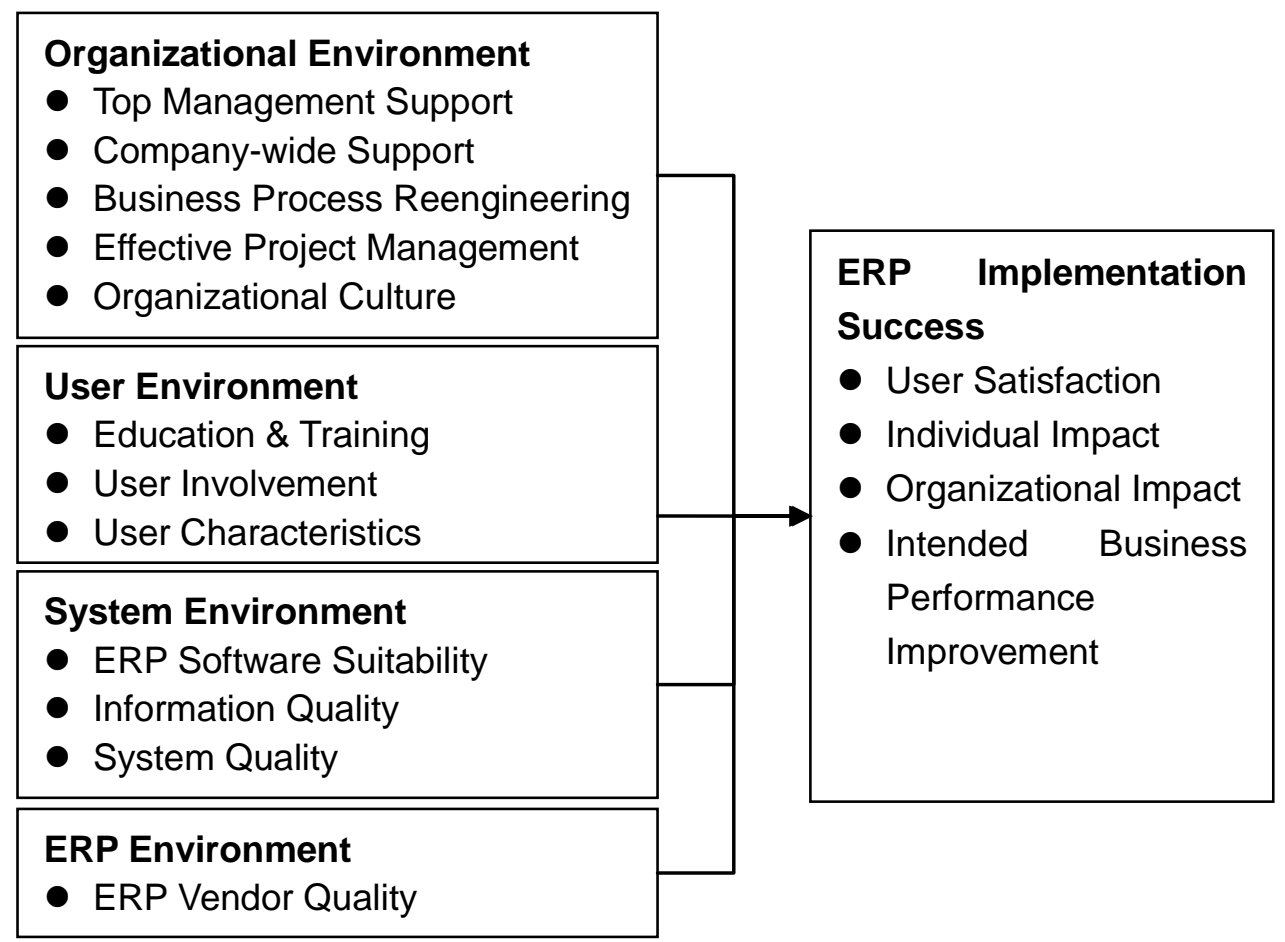

Figure 3.5 ERP Success and CSF Conceptual Framework (Zhang et al. 2005) 


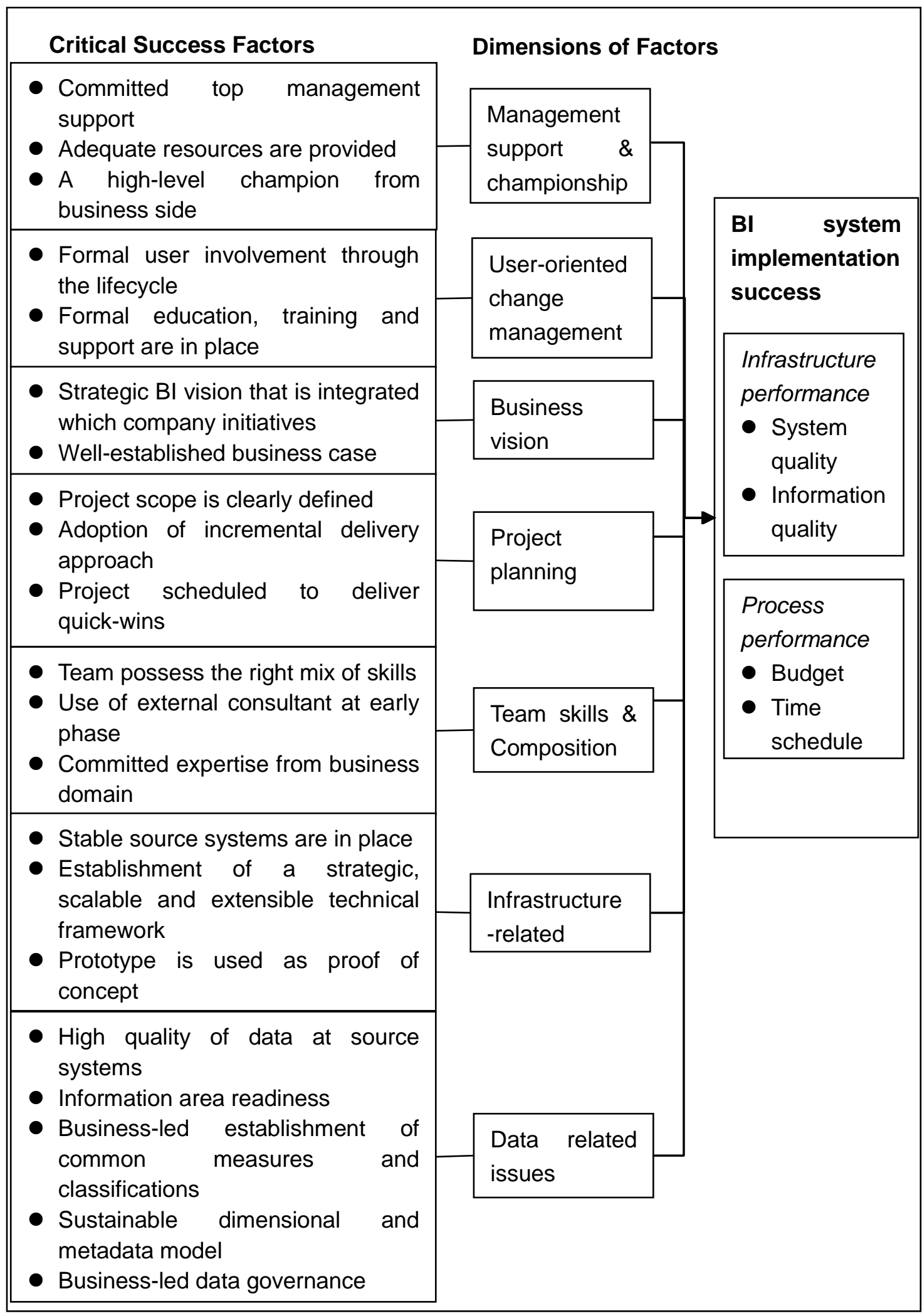

Figure 3.6 A CSF Framework for The Implementation of Business Intelligence System (Yeoh et al. 2007) 
Yeoh et al. (2007) researched on Business Intelligence Systems and provided comprehensive CSF framework for successful implementation of Business Intelligence Systems, particularly in engineering asset management enterprises. The framework covered seven dimensions of CSF and integrated with the implementation success measures, as shown in Figure 3.6 above.

Zhai et al.(2008) presented IS/IT Project CSF Model(see Figure 3.7) including three categories with nine factors:(1) Factors related to project stakeholders(Top management, Project manager, Project members, and Users); (2) Project support factors(Communication management and Relationship management); (3) Factors related to project life cycle(Project definition, Project plan, and Project control and change management).

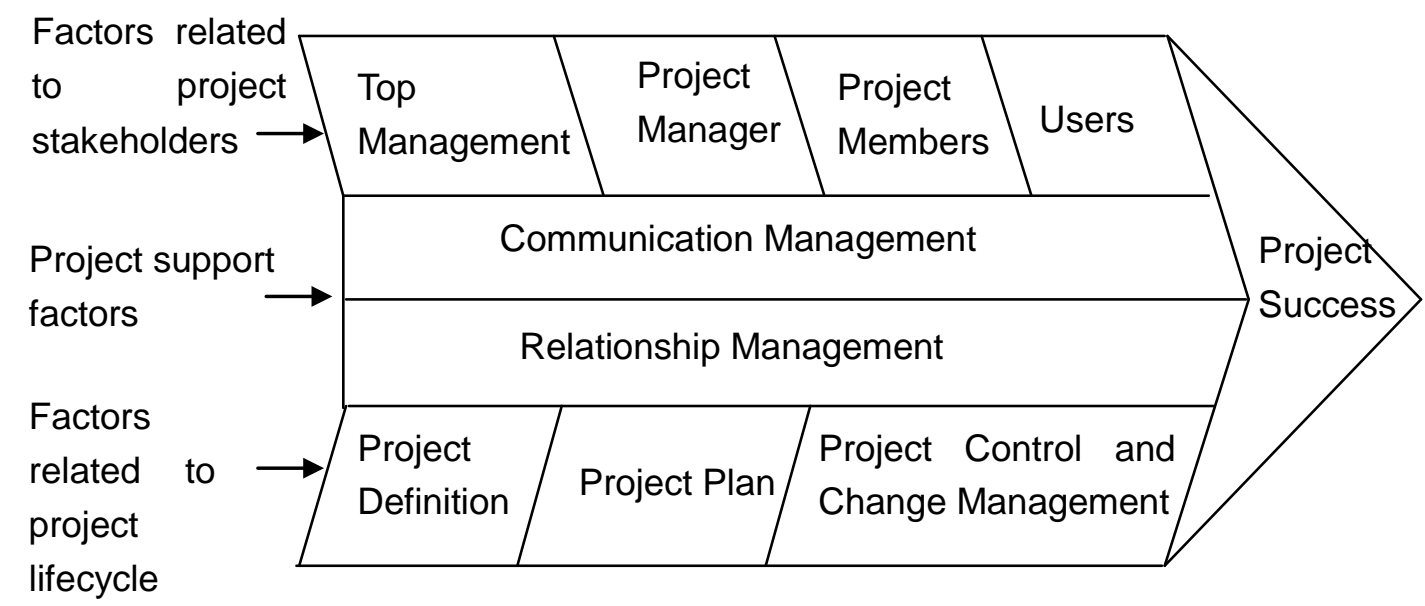

Figure 3.7 IS/IT Project CSFs Model (Zhai et al. 2008)

Both chapter 2 and this chapter are literature review which help the semi-structured interview and questionnaire design. In summary, the review of food TS implementation provides better understanding on the status of traceability systems implementation in China and is useful for interview design and administration, especially for forming nine questions 
in section one in the interview outline. The review of system success and critical success factors are deepening our understanding on concepts and research methods which are useful for interview analysis and questionnaire design.

Six of the 20 CSF which reported in the literature (see Table 3.2) are used to extract underlying factors to form part of the questionnaire items. The six factors are top management support, project management, communication, testing and trouble shouting, clear goals and objectives and vendor support. The review of the relevant CSF models/frameworks in information systems helps to understand the relevant work in the development of CSF framework.

\subsection{Chapter Summary}

This chapter reviews information system success including the definition and measures of system success, and information system success model/framework. The most commonly used success measures are those proposed by DeLone and McLean (2003) as use, user satisfaction and net benefits. However, as stressed by DeLone and McLean (2003), net benefit should be further defined according to the application context of the system. Therefore, it is essential for his study to first establish the specific success measures of the food traceability system implementation in China. Critical success factors identified in the literature are summarized which inform the design of this study. 


\section{Chapter 4: Research Method}

\subsection{Research Approaches}

Since the terms quantitative and qualitative are used widely in business and management research to differentiate both data collection techniques and data analysis procedures, the selection of research approach is based on the discussion of quantitative vs. qualitative. The differences between quantitative and qualitative research strategies are shown in Table 4.1.

Table 4.1 Fundamental Differences between Quantitative and Qualitative Research Strategies (Bryman 2004)

\begin{tabular}{|l|l|l|}
\hline & Quantitative & Qualitative \\
\hline $\begin{array}{l}\text { Principal orientation to the role of } \\
\text { theory in relation to research }\end{array}$ & $\begin{array}{l}\text { Deductive; testing of } \\
\text { theory }\end{array}$ & $\begin{array}{l}\text { Inductive; generation } \\
\text { of theory }\end{array}$ \\
\hline Epistemological orientation & $\begin{array}{l}\text { Natural science model, } \\
\text { in particular positivism }\end{array}$ & Interpretivism \\
\hline
\end{tabular}

Quantitative is predominantly used as synonym for any data collection technique (such as questionnaire) or data analysis procedure (such as graphs or statistics) that generates or uses numerical data. In contrast, qualitative is used predominantly as a synonym for any data collection technique (such as an interview) or data analysis procedure (such as categorising data) that generates or uses numerical data(Bryman 2004).

Selection between them depends on the practice of research method and its technique, maybe one of them or both mixed according to research purpose. For this study, the research method will combine qualitative and 
quantitative ways together.

\subsection{Selection of Research Strategies}

In current literature, the most popular research strategies are questionnaire survey, semi-structured or in-depth interviews, focus group, case study and observation.

According to 21 literatures from Table 3.1 in Section 3.2.2, the frequencies of different strategies used are summarized in Table 4.2.

Table 4.2 the Use Frequency of Research Different Strategies

\begin{tabular}{|l|c|c|c|}
\hline & Theoretical Study & Empirical Study & Total \\
\hline Literature Review(LR) & 2 & 0 & 2 \\
\hline LR + Case Study(CS) & 2 & 4 & 6 \\
\hline LR + Questionnaire Survey(QS) & 0 & 9 & 9 \\
\hline LR + Interview & 1 & 1 & 2 \\
\hline LR+ Interview+ QS & 0 & 1 & 1 \\
\hline LR + Delphi & 0 & 1 & 1 \\
\hline Total & 5 & 16 & 21 \\
\hline
\end{tabular}

It can be seen from the table that questionnaire survey is most frequently used in empirical study while literature review is commonly used in building theory. In addition, non-structured and semi-structured interviews are usually used in qualitative analysis while structured interview is used in quantitative analysis.

Based on the research objectives and the review on the appropriateness of different research strategies and their use in IS research, semi-structured interview and questionnaire survey are considered most appropriate and will be adopted in this study. The interview can help collect managers' 
views on TS implementation success and obtain success measures and additional important factors which have not been found in the literature or special for implementing food traceability system. Questionnaire survey can help extract CSF through exploratory factor analysis, and data analysis results will be used for proposing CSF framework.

\subsection{Semi-structured Interview}

\subsubsection{Interview Design}

In semi-structured interviews the researcher will have a list of themes and questions to be covered, although these may vary from interview to interview (Saunders et al. 2009). That means the need to omit some questions in particular interviews and to give a specific organizational context that is encountered relative to the research topic. In addition, the participant information sheet (see Appendix B) is also been designed for interviewees before distributing the interview outline to them.

The main body of interview outline (See Appendix C) includes three sections. The first section has nine questions for obtaining the basic information about the company and TS implementation. The second section aims to collect the views of interviewees on TS implementation success and measures. The final section is an open question that gives the interviewees the opportunity to talk about what are the critical factors that affecting TS implementation success.

\subsubsection{Interview Administration}

Six interviewees in four typical food companies in China were contacted and accepted interview. The information on interview is listed in Table 4.3. 
All interviews were conducted in early 2010. The interviews were carried out through face to face and telephone.

Table 4.3 Information on Interviews

\begin{tabular}{|l|l|l|l|}
\hline & \multicolumn{1}{|c|}{ Date } & Type of interview & \multicolumn{1}{c|}{ Position } \\
\hline Company I & ${\text { January } 26^{\text {th }}}^{\text {Company II }}$ & Face to face & $\begin{array}{l}\text { Ms. A, General Manager Assistant } \\
\text { Mr. B, Department Manager }\end{array}$ \\
\hline Company III & February $^{\text {th }}$ & Face to face & $\begin{array}{l}\text { Mr. C, system implementation-on } \\
\text { project leader }\end{array}$ \\
\hline Company IV & February $27^{\text {th }}$ & Telephone & $\begin{array}{l}\text { Mr. D, Deputy General Manager / } \\
\text { to face }\end{array}$ \\
\hline
\end{tabular}

\subsection{Questionnaire Survey}

Survey questionnaires will be distributed to a wider range of stakeholders of TS implementation. The survey results will be used to identify dimensional CSF in the context of Chinese food industry and propose a CSF framework.

\subsubsection{Questionnaire Design}

The instrument adopted is a self-administered questionnaire which has three parts. The first part is a cover letter (see Appendix D) introducing the contents, the purpose and significance of this study. The measures of "TS implementation success" and the definition of "critical success factor" for this study were provided at the very beginning of the questionnaire with an attempt to ensure that the participants were clear about what 'TS implementation success' means in the context of this research. The second part of the questionnaire is a list of 32 factors/variables based on the literature review and the results of semi-structured interviews. The 
respondents are asked to indicate their opinions on the importance of the factors provided in the survey using a 5-point Likert-scales (1= non important; 2= little important; 3= important; 4= very important; 5= extremely important) (Nah and Delgado 2006) (see Appendix E). The details of the factors will be discussed and presented in next chapter. The third part collects respondent profile such as their personal and organisational information.

In order to ensure the content validity of the questionnaire, most of the measuring instruments of this study were adopted from previous literature. As the references are mostly in English and this research intends to collect information from China, the questionnaire was originally established in English and then translated into Chinese. In order to ensure the consistencies of the instruments and the correct understanding of the respondents, four bilingual translators were invited to translate and back-translate the questionnaire. Without any change in the meanings, some ambiguous expressions were properly modified after discussions so that the questionnaire is more suitable to Chinese respondents and easier to be accepted and understood by Chinese respondents.

Moreover et al. (2009)argue that pilot tests can be used to improve the content validity and face validity of the questionnaire. Thus, the initial questionnaire was tested with experts and researchers. Through the pilot tests, valuable feedback was collected, such as missing options, repeated questions or improper expressions in the questionnaire. The questionnaire was eventfully revised and improved before the final distribution.

\subsubsection{Questionnaire Administration}

The selected population in this study involved people who has participated 
in the implementation of traceability system in food enterprises include stakeholders of experts, general managers, department managers, project managers, manager assistants, system implementation commissioners, system operators and so on.

About 400 survey questionnaires were distributed to about 41 experts and 83 food enterprises in Beijing, Shandong, Hainan, and Guangxi et al. The questionnaires and cover letters were emailed to the sampled subjects, and the respondents were asked to feedback via email or online transmission tool such as $\mathrm{QQ}$ within two weeks. A reminder email was sent to the non-respondents two weeks after the questionnaires were emailed. The survey was conducted over a period of three months from May 2010 to July 2009. A total of 129 questionnaires were collected but 3 were not usable because of incompleteness of the questionnaires concerned.

To ensure the reliability of the questionnaire collected, the completed questionnaires were initially screened for obvious errors. For example, one method is to check whether respondents addressed the questionnaire seriously. If the results of a questionnaire tend to be the same, for instance, all the answers are "1" in one questionnaire, it may suggest that the questionnaire did not reflect the true thoughts of the respondents (Galobardes et al. 1998; Saunders et al. 2009). Therefore, a total number of 2 questionnaires failed to meet the requirements and were disregarded.

Although the sample size is recommended as the larger the better, many previous studies on CSF research with the sample size between 100 160. For example, the study on CSF of CRM technological initiatives in Canada received 132 respondents (Croteau and Li 2003), a study on CSF of web-based supply-chain management systems received 109 respondents 
(Ngai et al. 2004), a study about factors affecting the implementation success of Internet-based information systems in Korean had 120 respondents (Lee and Kim 2007), and the research on CSF of ERP in Indian SME's had 160 respondents(Dan 2009). Therefore, 124 valid questionnaires were considered as sufficient for this study.

\subsection{Chapter Summary}

This chapter discusses issues of research methods. The semi-structured interview and questionnaire survey design and administration are explained in detail. The next chapter will focus on interview and questionnaire data analysis. 


\section{Chapter 5: Data Analysis}

\subsection{Interview Analysis}

Information collected from four food companies is presented in Table 5.1.

Table 5.1 Company Profile

\begin{tabular}{|l|l|l|l|l|}
\hline & Company I & Company II & Company III & Company IV \\
\hline Status & $\begin{array}{l}\text { Beijing } \\
\text { agricultural } \\
\text { industrialization } \\
\text { key leading } \\
\text { enterprise }\end{array}$ & $\begin{array}{l}\text { National } \\
\text { agricultural } \\
\text { industrialization } \\
\text { key leading } \\
\text { enterprise }\end{array}$ & $\begin{array}{l}\text { Beijing } \\
\text { agricultural } \\
\text { industrialization } \\
\text { key leading } \\
\text { enterprise }\end{array}$ & $\begin{array}{l}\text { National } \\
\text { quality, } \\
\text { reputation, } \\
\text { service AAA } \\
\text { unit }\end{array}$ \\
\hline $\begin{array}{l}\text { System } \\
\text { adoption year }\end{array}$ & 2006 & 2006 & 2008 & 2007 \\
\hline $\begin{array}{l}\text { Who develop } \\
\text { the system }\end{array}$ & Vendor & Vendor & Vendor & Vendor \\
\hline Funding from & EU Programme & $\begin{array}{l}\text { National } 863 \\
\text { Project }\end{array}$ & $\begin{array}{l}\text { Beijing Municipal } \\
\text { Bureau of } \\
\text { Agriculture }\end{array}$ & $\begin{array}{l}\text { Beijing } \\
\text { Municipal } \\
\text { Bureau of } \\
\text { Agriculture }\end{array}$ \\
\hline $\begin{array}{l}\text { Traceable } \\
\text { products }\end{array}$ & Aquatic products & Meats and & $\begin{array}{l}\text { Vegetables and } \\
\text { fruits }\end{array}$ & Watermelon \\
\hline Market target & $\begin{array}{l}\text { China Japan, } \\
\text { abroad }\end{array}$ & $\begin{array}{l}\text { Mainland China, } \\
\text { Hongkong China, } \\
\text { Singapore }\end{array}$ & $\begin{array}{l}\text { Mainland } \\
\text { China }\end{array}$ \\
\hline $\begin{array}{l}\text { Education } \\
\text { background of } \\
\text { trace-related } \\
\text { employees }\end{array}$ & Junior college \\
and above & $\begin{array}{l}\text { Junior college } \\
\text { and above }\end{array}$ & $\begin{array}{l}\text { Junior college } \\
\text { and below, few } \\
\text { undergraduate }\end{array}$ & Junior college \\
\hline
\end{tabular}

In order to ensure the representativeness of the sample, the companies being chosen cover the national key leading enterprise (e.g. Company II), regional key leading enterprise (e.g. Company I ), and general enterprise (e.g. Company IV). The markets of the products are domestic (e.g. Company IV) and international markets (e.g. Company III). The traceable 
products cover vegetables, fruits, meats and aquatic products.

All the companies implemented TS in recent years and the systems are offered by vendors. The funding for the system implementation was from the grants of international or national projects and government programmes.

The purpose of the interview was mainly to collect opinions of managers and experts who have been involved in TS implementation on TS implementation success and to obtain specific factors affecting success. Based on the interview objectives, the following questions were asked. Examples of interviewees' answers are summarized as following:

1. What do you think of the reason why the company implements traceability system?

"Several food safety incidents happened, so the government paid great attention to food safety" (Ms. A, Mr. B, Mr. C, Mr. D, Ms.F)

"To prepare for the Olympic Games" (Ms. A, Mr. B, Mr. D, Ms F)

"To improve the reputation of the enterprise and product brand; the ultimate goal is to boost the net benefit" (Ms. A, Mr. B, Mr. C, Mr. D, Mr. E)

"The National 863 Project requires to enhance college academic research combined with business practice, the company which is a national model enterprise, was the first to join"(Mr. C)

"First, it is important to improve product quality; second, it demonstrates the company's commitment to consumers, consumers can intuitively understand the entire process of product life cycle" (Ms F) 
2. Has the company's economic benefit changed after its implementation of traceability system?

"Market share is expanded, annual sales increased $15 \%$ to $20 \%$, and economic and social benefits are enhanced" (Mr. D)

"There is not much change; Consumers' knowledge on traceability is limited, so the company pays more attention to brand awareness" (Ms F)

3. What is the change of product price after the implementation? What dose traceability costs include?

"System development funds are invested by the government project; system maintenance, data collection and labeling costs are not high, take 500 grams of vegetables in Company III for example, about 0.1 yuan RMB. But agricultural profits are relatively low, the company generally take 'small profits, quick returns', if add 0.1 yuan RMB to original price, it is not beneficial for sales, so to traceable product, it is prefer to publicize its advantage more than adding price"(Mr. E)

"Costs include fees of carbon paper, stickers, labor, equipment maintenance and and labels. Label cost is relatively small, take each watermelon in company IV for example, about 0.5 yuan RMB, the label cost accounted for about $0.5 \%$ of the products cost"(Ms F)

4. What are the difficulties or problems and the causes during the system implementation process?

"Workers have complained about the system, because the large amount of information collection, amount of label painting, the system is easy to go bad and the computer is always to crash"(Ms. A, Ms F) 
"high cost include label cost (RFID label is worth minimum one yuan RMB, two-dimensional code, the most cheap is worth several cents) and the hardware equipment cost (equipment costs are high for generally from abroad, and easy to consume); the operations are increased such as painting labels, affecting work efficiency; the staff educational level is relatively low and it is not easy to operate the system; the laboratory environment is ideal for operation, but the factory environment is noisy and complexity; Chinese consumers have not yet reached a certain level of consumption, and most people would rather choose the cheaper product" (Mr. C)

"In the initial period of the system implementation, the workers complained about the workload of information collection and input" (Mr. E)

5. What support would you like to receive from the government when implementing system?

"Financial support and policy support. Agricultural enterprise products have low profits; workers have low wages and work in remote locations, so it is difficult to recruit high-tech and administrative staff. There are two extremes - highly educated and not educated. The Government is currently tilted in the facilities and finances, but there are no preferential policy for brain" (Mr. E)“Technical support and financial support "(Ms F)

6. What do you think of the TS implementation success?

"If the corporate brands, reputation and net benefits have been improved through the implementation of the system, well, it is a successful implementation" (Ms. A) 
"The corporate brands and reputation are improved, food products are safety and well evaluated by the consumers that the objective of TS implementation is achieved, that the TS implementation is success."

"If the traceability system can achieve complete tracking, information can be automatically collected and transmitted to the database, bring the whole industry chain doing a good job, keep up with scientific research and technologies, the system implementation is successful" (Mr. C)

"First, system advocates think that is necessary for enterprise and also can give benefit to enterprise and workers; second, users can find the information they need and the information credibility is high; third, through traceability applied, the products are more trusted by consumers"( Mr. E)

"Information collection process is settled for all personnel in accordance with the systems requirement carefully collect information, input information; consumers can simply, quickly and accurately obtain the information they need, that can be considered as the successful implementation of traceability system. In addition, the system is available for enterprise, such as the preservation of information throughout the product life cycle process besides consumers want traceability or after problems" (Ms. F)

7. In your opinion, what are the main aspects for the traceability system success?

"System user satisfaction, and net benefit" (Mr. C)

"Evaluation of success mainly have three measures including operation time, benefits to enterprises, and information satisfies users' need" (Mr. E) 
"Embody in data accuracy, good performance of software, easy to use and enterprise benefit increase" (Ms F)

8. In your opinion, what are critical success factors for implementing traceability system in the company? (Including internal factors and external factors, and what is your view on these factors?)

"Government investment; government publicize food traceability; the credibility of information (business integrity);system performance, system cost; system availability"(Ms. A, Mr. B)

"Government support and enterprise top management support (economical, technical, management); enterprise integrity; management and communication; a good project manager; publicity for traceability; and training of related personnel" (Mr. C)

"Policy guidance; government and enterprise support; making correct decisions; communication and management in place" (Mr. D)

"Cost; technology; top management support; laws and regulations support; social support, as well as availability" (Mr. E)

Enterprise support, timely participation; government investment; education and training; laws and regulations support; social support. (Ms. F)

The aspects that referred in the interview of TS implementation success are listed as following:

- Brand and reputation improved (A, B)

- Net/enterprises benefits increased (A, C, E, F)

- Food safety and well evaluated by consumers $(B$,

- Products are more trusted by consumers(E)

- Information satisfy users' need (E) 
- consumers can simply, quickly and accurately obtain the information they need (F)

- Information credibility (E)

- Data accuracy (F)

- Information automatically collected and transmitted (C)

- System user satisfaction (C)

- Complete tracing and tracking (C)

- Good performance of software(F)

According to the research by DeLone and McLean(2003) about the measures of IS success, the choice of where the impacts should be measured will depend on the system or systems being evaluated and their purposes. Therefore, in this study, "net benefit" is too general as a measure for TS implementation. "Improved enterprise brand and reputation" and "food quality and safety" seem to be the contents of net benefit considering of the objective of implementing TS and the specific characteristics of TS.

Thus, based on literature review (e.g. D\&M Model) and results of the interview, the measures of TS implementation success in Chinese food enterprises are "system users' (e.g. employees in the company) satisfaction, information users' (e.g. consumers) satisfaction, improved food quality and safety, and enhanced brand and enterprise reputation."

The interview has also explored the interviewees' views on CSF. The information collected on CSF is summarized as following:

- Policy guidance; laws and regulations support;

- Government investment;

- Publicize food traceability; social support; 
- Enterprise top management support; enterprise support, timely participation

- Management and communication;

- Education and training; training of related personnel; a good project manager; making correct decisions;

- The credibility of information;

- Technology; system performance; system availability

The factors from the interviews, e.g. policy guidance, laws and regulations support, government investment, publicizing food traceability, the credibility of information, are specific for TS implementation in the China context and were used to form the questionnaire items. The factors mentioned in the interviews and factors reviewed in the literature were both used for questionnaire design. More details in relation to this can be found in Appendix E.

\subsection{Questionnaire Data Analysis}

\subsubsection{Analysis of Demographic Characteristics}

A summary of the demographic characteristics of the sample is shown in Table 5.2.

From the table, we can see that the positions of respondents which include general manager (10.5\%), department manager (13.7\%), project manager (10.5\%), manager assistant (15.3\%), expert (15.3\%), system implementation commissioner (17.7\%), and system operator (16.9\%) are over all areas relative with system implementation and the sample distribution is balanced. The implementation experience of most respondents are more than 2 years include 2 3 years (55.6\%), 4-6 years 
(24.2\%), over 7 years (8.9\%). The data present that the respondents have sufficient system implementation knowledge to estimate the critical success factors for implementing systems in enterprises. The majority of respondents are undergraduate and higher(70.2\%), and the other three which include junior college, high school, Junior high school and lower are accounted for $21.0 \%, 7.3 \%$ and $1.6 \%$ respectively. $71.8 \%$ respondents have received the education and training of system implementation, but still the $28.2 \%$ have not.

Table 5.2 Profile of Respondents

\begin{tabular}{llll}
\hline & Frequency & $\begin{array}{l}\text { Valid } \\
\text { Percent }\end{array}$ & $\begin{array}{l}\text { Cumulative } \\
\text { Percent }\end{array}$ \\
\hline Position & 13 & 10.5 & 10.5 \\
General manager & 17 & 13.7 & 24.2 \\
Department manager & 13 & 10.5 & 34.7 \\
Project manager & 19 & 15.3 & 50.0 \\
Manager assistant & 19 & 15.3 & 65.3 \\
Expert & 22 & 17.7 & 83.1 \\
System implementation commissioner & 21 & 16.9 & 100.0 \\
System operator & 124 & 100.0 & \\
Total & & & \\
Implementation Experience & 14 & 11.3 & 11.3 \\
In 1 year & 69 & 55.6 & 66.9 \\
2-3 years & 30 & 24.2 & 91.1 \\
4-6 years & 11 & 8.9 & 100.0 \\
over 7 years & 124 & 100.0 & \\
Total & & & \\
Education Background & 2 & 1.6 & 1.6 \\
Junior high school and lower & 9 & 7.3 & 8.9 \\
High School & 26 & 21.0 & 29.8 \\
Junior college & 87 & 70.2 & 100.0 \\
Undergraduate and higher & 124 & 100.0 & \\
Total & & & \\
Whether have got education or training & 89 & 71.8 & 71.8 \\
Yes & 35 & 28.2 & 100.0 \\
No & 124 & 100.0 & \\
Total & & &
\end{tabular}

\subsubsection{Analysis of Descriptive Statistics}

A descriptive analysis of the data is shown in Table 5.3. All 32 variables 
mean value are more than 3.0, therefore, all of these factors are considered important for implementing TS in food enterprises by participants.

Top 15 factors are discussed in this section. We can see from the table that the top critical important factor which influences system implementation success is "The authenticity of traceability information (V28)". Information authenticity or data accuracy is always the most important factor related to any information system implementation. Traceability information authenticity not only reflects information/system quality but also influences the trust between enterprises and users/consumers. The second and third factors are "Perfect food traceability laws (V2)" and "Perfect food traceability standards (V3)". Especially in China, food traceability system application is in primary stage, available laws and standards as well as the regulations (V1) are needed for effective traceability implementation. The fourth factor is "Clear objectives for TS implementation (V15)" and according to Ernst \&Young (2006) the presence of clear strategic goals is the fourth most important CSF out of nine. The fifth factor is "Policy guidance for enterprises TS implementation from government (V4)" which indicates the importance of government support in China. The sixth factor is "The specific function of TS satisfying users' need (V31)". The eighth factor "The standardization of traceability information identification (V29)" is specifically important in traceability system implementation. Since globalization of trade and the lack of international standards have made identifying the origin and history of products difficult (Sioen et al. 2007), the standardization of traceability information is urgently needed. 
Table 5.3 Descriptive Statistics

\begin{tabular}{|c|c|c|c|c|}
\hline & Variables & Mean & Std. D & Rank \\
\hline V28 & The authenticity of traceability information & 4.50 & 0.770 & 1 \\
\hline V2 & Perfect food traceability laws & 4.43 & 0.808 & 2 \\
\hline V3 & Perfect food traceability standards & 4.40 & 0.835 & 3 \\
\hline V15 & Clear objectives for TS implementation & 4.22 & 0.822 & 4 \\
\hline V4 & Policy guidance for enterprises TS implementation from government & 4.20 & 0.796 & 5 \\
\hline V31 & The specific function of TS satisfying users' need & 4.19 & 0.820 & 6 \\
\hline V1 & Perfect food traceability regulations & 4.18 & 0.902 & 7 \\
\hline V29 & The standardization of traceability information identification & 4.09 & 0.884 & 8 \\
\hline V14 & $\begin{array}{l}\text { TS implementation being taken into corporate strategy by top } \\
\text { management }\end{array}$ & 4.08 & 0.916 & 9 \\
\hline V26 & The effectiveness of traceability information & 4.07 & 0.857 & 10 \\
\hline V12 & $\begin{array}{l}\text { Support for TS implementation from all functional departments in } \\
\text { enterprises }\end{array}$ & 3.96 & 0.849 & 11 \\
\hline V19 & Trouble shooting in time & 3.92 & 1.009 & 12 \\
\hline V22 & Trust between upstream and downstream companies & 3.90 & 1.055 & 13 \\
\hline V23 & Timely communication between upstream and downstream companies & 3.89 & 1.053 & 14 \\
\hline V27 & The integrity of traceability information & 3.89 & 1.030 & 15 \\
\hline V20 & Responsible administrators & 3.88 & 1.041 & 16 \\
\hline V8 & Food traceability publicity to consumers from the Government & 3.85 & 0.963 & 17 \\
\hline V17 & Specific and rigorous arrangements for TS implementation & 3.83 & 0.793 & 18 \\
\hline V5 & Funding for TS implementation from government & 3.81 & 0.966 & 19 \\
\hline V13 & System operation and maintenance investment & 3.72 & 0.984 & 20 \\
\hline V32 & Easy operation of TS & 3.72 & 0.812 & 21 \\
\hline V11 & Continuous support from vendors for TS implementation & 3.68 & 0.898 & 22 \\
\hline V18 & TS operation according to schedule strictly & 3.67 & 0.908 & 23 \\
\hline V24 & Easy communication between upstream and downstream companies & 3.66 & 1.027 & 24 \\
\hline V25 & Sharing information between upstream and downstream companies & 3.65 & 0.973 & 25 \\
\hline V21 & Education and training for employees & 3.64 & 0.769 & 26 \\
\hline V9 & Willingness to pay from consumer for traceable food & 3.63 & 0.932 & 27 \\
\hline V10 & Full understanding of food traceability from consumers & 3.62 & 0.870 & 28 \\
\hline V16 & Top management involvement in TS implementation & 3.59 & 0.988 & 29 \\
\hline V30 & Excellent performance of TS & 3.58 & 0.777 & 30 \\
\hline V6 & Equipment investment for TS implementation from government & 3.46 & 1.015 & 31 \\
\hline V7 & Technology support for TS implementation from government & 3.29 & 1.002 & 32 \\
\hline
\end{tabular}


The ninth factor "TS implementation being taken into corporate strategy by top management (V14)" occupies the important position in any system implementation in enterprises. "Top management support" is one of the most frequently used terms in CSF literature. The tenth factor is "The effectiveness of traceability information (V26)" which indicates that the information needs not only to be accurate but also effective and can satisfy consumers' actual requirement. The eleventh factor "Support for TS implementation from all functional departments in enterprises (V12)" means the importance of company-wide support. Since traceability systems are enterprises-wide information management systems and across all most functional areas in all organization, it is imperative to get support from all functional segments of the organization. The twelveth factor is "Trouble shooting in time (V19)" that presents the ability of trouble shooting and effectiveness of project management. The next two factors are "Trust between upstream and downstream companies (V22)" and "Timely communication between upstream and downstream companies (V23)" highlights the importance of trust and communication between upstream and downstream companies for implementing systems. The final factor is "The integrity of traceability information (V27)" which indicates that users/consumers need integrated information across the whole traceability steps. For example, a search with key words can retrieve the completed traceability information of particular products quickly.

\subsubsection{Exploratory Factor Analysis(EFA)}

\subsubsection{Why EFA}

Factor analysis addresses the problem of analysing the structure of the interrelationships (correlations) among a large number of variables (e.g. 
questionnaire responses) by defining a set of common underlying dimensions(Hair et al. 1995). A large number of variables have been identified in the literature affecting the IS implementation success, but no previous research has investigated the CSF in the context of food traceability system implementation in Chinese food industry. This study attempted to understand the underlying dimensions contributing to TS implementation success. Factor analysis was chosen to help categorise the indentified CSF into a set of uncorrelated dimensions with a minimum loss of information.

With factor analysis, the researcher can first identify the separate dimensions of the structure and then determine the extent to which variables is explained by each dimension(Hair et al. 1995). One primary use of factor analysis, according Hair et al (1995) is to summarize the data. In summarising the data, the factor analysis derives underlying dimensions that, when interpreted and understood, describe the data in a much smaller number of concepts than the original individual variables. It is believed that the findings factor analysis in this context is valuable for both research and practice as it help researchers and managers to be more focused and address the key areas more effectively.

Exploratory Factor Analysis (EFA) is often recommended when researchers have no hypotheses about the nature of the underlying factor structure of the variables.

\subsubsection{EFA Process}

An exploratory factor analysis (EFA) with a varimax rotation was conducted on 32 items in questionnaire. Before conducting EFA, two test were performed to check the possible presence of multicollinearity or correlation 
among the CSFs: the Kasier-Meyer-Olkin (KMO) measuring sampling adequacy, and the Bartlett test of sphericity for testing the presence of correlation (Ngai et al. 2004). Bartlett's test requires that the significance value should be less than 0.05 ( $\mathrm{p}<0.05)$, moreover, the $\mathrm{KMO}$ value should be greater than 0.6 (Tabachnick and Fidell 2001), a value of between 0.8 and 0.9 is better. In this study, as shown in Table 5.4, the KMO value is 0.854 and the Bartlett's test reached statistical significance $(p=.0000)$. Therefore, it is appropriate to conduct the factor analysis.

Table 5.4 KMO and Bartlett's Test

\begin{tabular}{lll}
\hline Kaiser-Meyer-Olkin Measure of Sampling Adequacy. & 0.854 \\
\hline Bartlett's Test of Sphericity & Approx. Chi-Square & $2.863 \mathrm{E} 3$ \\
& df & 496 \\
& Sig. & .000 \\
\hline
\end{tabular}

In the first EFA, as shown in Table 5.5 and Figure 5.1, the initial solution contained 8 factors with eigenvalues of above 1.0, and the proportion of the variance explained by the 8 factors was $73.93 \%$. After rotation we can see that the distribution of the variance explained has been adjusted. 


\section{Scree Plot}

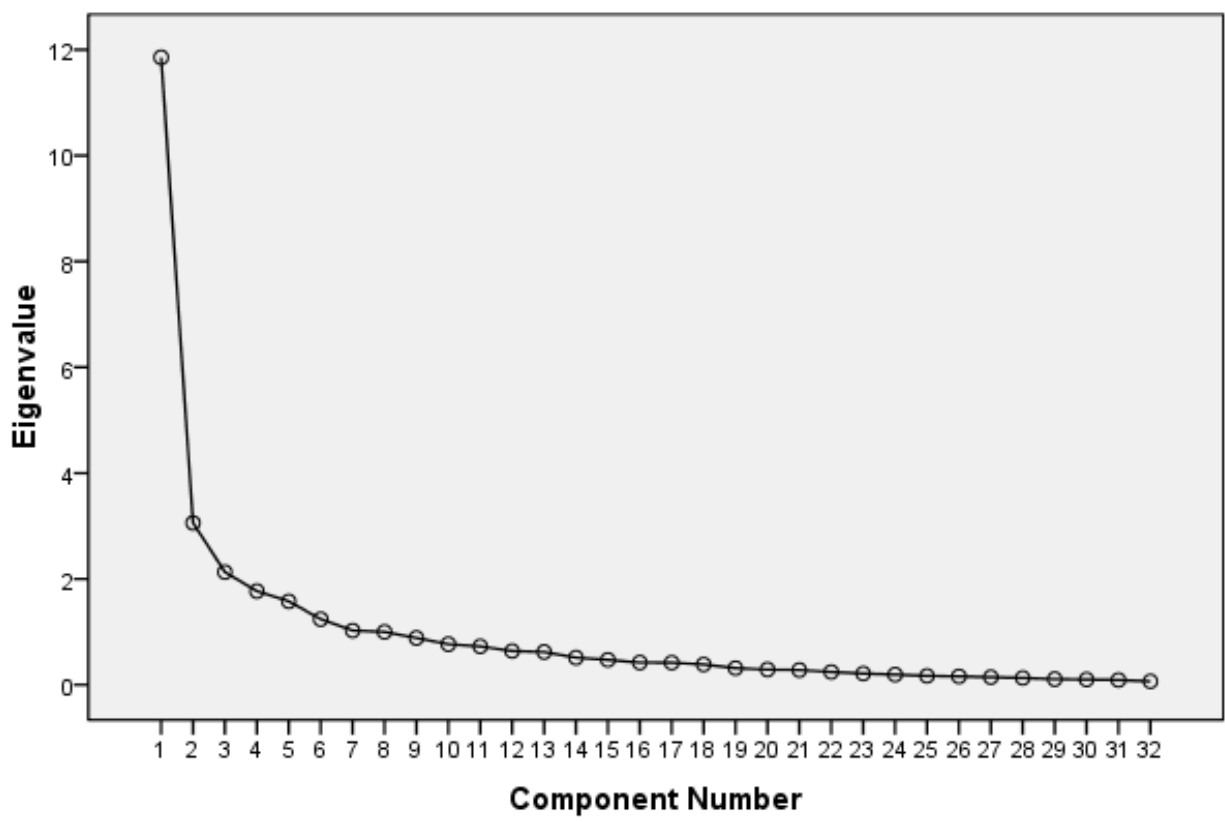

Figure 5.1 Scree Plot

Table 5.5 Total Variance Explained (First EFA)

\begin{tabular}{|c|c|c|c|c|c|c|}
\hline \multirow{2}{*}{ Factors } & \multicolumn{3}{|c|}{ Initial Eigenvalues } & \multicolumn{3}{|c|}{$\begin{array}{l}\text { Rotation Sums of Squared } \\
\text { Loadings }\end{array}$} \\
\hline & Total & $\begin{array}{l}\% \text { of } \\
\text { Variance }\end{array}$ & $\begin{array}{l}\text { Cumulative } \\
\%\end{array}$ & Total & $\begin{array}{l}\% \\
\text { Variance }\end{array}$ & $\begin{array}{l}\text { Cumulative } \\
\%\end{array}$ \\
\hline 1 & 11.856 & 37.051 & 37.051 & 4.277 & 13.367 & 13.367 \\
\hline 2 & 3.059 & 9.558 & 46.609 & 3.753 & 11.727 & 25.093 \\
\hline 3 & 2.131 & 6.659 & 53.268 & 3.526 & 11.018 & 36.111 \\
\hline 4 & 1.770 & 5.531 & 58.798 & 3.139 & 9.809 & 45.921 \\
\hline 5 & 1.578 & 4.930 & 63.728 & 3.044 & 9.513 & 55.433 \\
\hline 6 & 1.240 & 3.876 & 67.604 & 2.172 & 6.789 & 62.222 \\
\hline 7 & 1.025 & 3.204 & 70.808 & 2.080 & 6.501 & 68.723 \\
\hline 8 & 1.000 & 3.125 & 73.933 & 1.667 & 5.210 & 73.933 \\
\hline
\end{tabular}


Table 5.6 Rotated Component Matrix ${ }^{a}$ (First EFA)

\begin{tabular}{|c|c|c|c|c|c|c|c|c|}
\hline & \multicolumn{8}{|c|}{ Component } \\
\hline & 1 & 2 & 3 & 4 & 5 & 6 & 7 & 8 \\
\hline V26 & .783 & .131 & .296 & -.033 & .285 & .112 & .075 & .185 \\
\hline V27 & .821 & .076 & .264 & -.104 & -.030 & .279 & .135 & .016 \\
\hline V28 & .603 & .260 & .058 & .137 & .512 & .039 & -.123 & .127 \\
\hline V29 & .636 & .155 & .176 & -.010 & .240 & .269 & -.063 & .359 \\
\hline V30 & .659 & .049 & .182 & .384 & -.054 & .056 & .390 & .052 \\
\hline V31 & .635 & .107 & .214 & .375 & .148 & .054 & .135 & .093 \\
\hline V9 & .049 & .593 & -.011 & .158 & .553 & .027 & -.003 & -.274 \\
\hline V10 & .051 & .672 & .064 & .270 & .251 & -.253 & .146 & .079 \\
\hline V14 & .317 & .451 & .240 & .088 & .133 & .352 & -.392 & .305 \\
\hline V15 & .126 & .463 & .239 & .317 & .357 & .199 & -.372 & .198 \\
\hline V17 & .426 & .478 & .244 & .387 & -.051 & .251 & .172 & .010 \\
\hline V18 & .243 & .520 & .076 & .447 & .358 & -.042 & .184 & .155 \\
\hline V19 & -.005 & .587 & .397 & .463 & .087 & .007 & .228 & .053 \\
\hline V20 & .318 & .523 & .510 & -.012 & -.062 & .197 & .258 & .094 \\
\hline V21 & .247 & .742 & .269 & .102 & .047 & .113 & .138 & .118 \\
\hline V22 & .140 & .264 & .581 & .285 & .444 & .019 & -.050 & .033 \\
\hline V23 & .360 & .260 & .707 & .007 & .162 & .248 & .005 & .099 \\
\hline V24 & .212 & .242 & .774 & .179 & -.011 & .237 & .138 & .171 \\
\hline V25 & .302 & .026 & .775 & .177 & .083 & .045 & .041 & .025 \\
\hline V11 & .067 & .146 & -.103 & .620 & .331 & .153 & .027 & .241 \\
\hline V12 & .135 & .160 & .242 & .752 & .159 & -.032 & -.008 & -.012 \\
\hline V13 & .258 & .195 & .096 & .518 & .263 & -.270 & .007 & .474 \\
\hline V16 & -.164 & .416 & .204 & .573 & .141 & .195 & -.024 & -.038 \\
\hline V3 & .221 & -.027 & .190 & .356 & .626 & .320 & .023 & .067 \\
\hline V4 & .032 & .065 & .277 & .153 & .686 & .157 & .015 & .228 \\
\hline V8 & .172 & .278 & -.122 & .156 & .669 & .092 & .280 & -.189 \\
\hline V1 & .224 & .051 & .263 & .037 & .134 & .745 & .091 & -.109 \\
\hline V2 & .301 & -.015 & .111 & .111 & .276 & .742 & .023 & .262 \\
\hline V6 & .131 & .252 & .279 & -.155 & .192 & -.082 & .767 & .095 \\
\hline V7 & .231 & .128 & -.027 & .298 & .010 & .224 & .710 & .021 \\
\hline V5 & -.008 & .341 & .345 & -.086 & .245 & .312 & .381 & .445 \\
\hline V32 & .411 & .035 & .128 & .200 & -.064 & .075 & .058 & .713 \\
\hline
\end{tabular}


The rotated factor matrix shows the loadings of each of the variables on the selected eight factors, and given the size of this value we can identify the most representative variables for each of factors. Factor loading refers to the degree of correlation between variables and factors, and in general, the requirements for this value should be no less than 0.3 (Pallant 2005). Some scholars believe that when the variables have loadings greater than 0.4 , it is considered to be relatively significant. When loadings are greater than 0.5 , it is considered to be very significant. When loadings are greater than 0.6, it indicates that the variables are highly correlated with each other (Hair et al. 1995; Zeng and Huang 2005). The results in Table 5.6 show the loadings of 32 variables. 28 of them are greater than 0.5 , which indicate the variables are very significant. Therefore, four variables (V5, V14, V15, V17) which are lower than 0.5 and highlighted with brown colour fit were removed. The remaining 28 variables are for second EFA.

Table 5.7 Total Variance Explained (Second EFA)

\begin{tabular}{|l|l|l|l|l|l|l|}
\hline \multirow{2}{*}{ Factors } & \multicolumn{3}{|l|}{ Initial Eigenvalues } & \multicolumn{2}{l|}{$\begin{array}{l}\text { Rotation } \\
\text { Loadings Sums of Squared }\end{array}$} \\
\cline { 2 - 7 } & \multirow{2}{*}{ Total } & $\begin{array}{l}\% \\
\text { Variance }\end{array}$ & $\begin{array}{l}\text { Cumulati } \\
\text { ve } \%\end{array}$ & Total & $\begin{array}{l}\text { \% of } \\
\text { Variance }\end{array}$ & $\begin{array}{l}\text { Cumulative } \\
\%\end{array}$ \\
\hline 1 & 10.267 & 36.667 & 36.667 & 4.244 & 15.156 & 15.156 \\
2 & 2.979 & 10.641 & 47.307 & 4.229 & 15.104 & 30.261 \\
3 & 1.964 & 7.013 & 54.321 & 3.483 & 12.439 & 42.700 \\
4 & 1.600 & 5.716 & 60.037 & 3.110 & 11.109 & 53.809 \\
5 & 1.482 & 5.293 & 65.329 & 2.415 & 8.625 & 62.434 \\
6 & 1.184 & 4.230 & 69.559 & 1.995 & 7.124 & 69.559 \\
\hline
\end{tabular}

In the second EFA, as shown in Table 5.7, the initial solution contained 6 factors with eigenvalues of above 1.0, and the proportion of the variance explained by the 6 factors was $69.56 \%$. The rotation results are presented 
in Table 5.8. The loading of V4 is 0.409 that lower than 0.5 which is removed. Therefore, the remaining 27 variables are used for further data analysis.

Table 5.8 Rotated Component Matrix ${ }^{\mathrm{a}}$ (Second EFA)

\begin{tabular}{|c|c|c|c|c|c|c|}
\hline & \multicolumn{6}{|c|}{ Component } \\
\hline & 1 & 2 & 3 & 4 & 5 & 6 \\
\hline V19 & .584 & -.023 & .510 & .311 & -.062 & .250 \\
\hline V20 & .733 & .272 & .015 & .170 & .045 & .300 \\
\hline V21 & .591 & .216 & .169 & .402 & -.070 & .237 \\
\hline V22 & .550 & .182 & .351 & .362 & .214 & -.137 \\
\hline V23 & .750 & .361 & .039 & .123 & .298 & .000 \\
\hline V24 & .813 & .228 & .211 & -.049 & .231 & .114 \\
\hline V25 & .670 & .273 & .171 & -.059 & .201 & .022 \\
\hline V26 & .311 & .799 & -.016 & .214 & .219 & .118 \\
\hline V27 & .328 & .709 & -.197 & -.013 & .264 & .285 \\
\hline V28 & .107 & .646 & .195 & .498 & .187 & -.121 \\
\hline V29 & .236 & .722 & .054 & .144 & .295 & .009 \\
\hline V30 & .213 & .561 & .286 & -.050 & .084 & .517 \\
\hline V31 & .224 & .601 & .331 & .108 & .140 & .218 \\
\hline V32 & .171 & .641 & .341 & -.228 & -.001 & .102 \\
\hline V11 & -.081 & .160 & .675 & .242 & .222 & .020 \\
\hline V12 & .221 & .086 & .735 & .107 & .097 & .105 \\
\hline V13 & .095 & .441 & .670 & .182 & -.167 & -.016 \\
\hline V16 & .336 & -.209 & .596 & .228 & .170 & .097 \\
\hline V18 & .242 & .277 & .526 & .513 & -.021 & .205 \\
\hline V8 & -.091 & .103 & .164 & .719 & .272 & .265 \\
\hline V9 & .159 & -.055 & .197 & .797 & .103 & .061 \\
\hline V10 & 310 & .079 & .387 & .583 & -.302 & .102 \\
\hline V1 & .331 & .123 & -.060 & .045 & .720 & .155 \\
\hline V2 & .140 & .353 & .126 & .038 & .751 & .088 \\
\hline V3 & .095 & .277 & .388 & .339 & .577 & -.044 \\
\hline V4 & 163 & .182 & .298 & .406 & .409 & -.096 \\
\hline V6 & .332 & .140 & $\mid-.109$ & .300 & -.073 & .656 \\
\hline V7 & .047 & .126 & .216 & .074 & .172 & .835 \\
\hline
\end{tabular}


The final EFA showed that the factor patterns remained constant and six dimensional critical success factors explained $70.616 \%$ of the total variance among the remaining 27 variables. Table 5.9 summarizes the results of the factor analysis.

Table 5.9 Results of Final EFA

\begin{tabular}{lllllll}
\hline Variables & Factor 1 & Factor 2 & Factor 3 & Factor 4 & Factor 5 & Factor 6
\end{tabular}

\begin{tabular}{|c|c|c|c|c|c|c|}
\hline V1 & .739 & .123 & .068 & -.043 & .332 & .137 \\
\hline V2 & .740 & .070 & .044 & .142 & .144 & .371 \\
\hline V3 & .554 & -.061 & .341 & .403 & .102 & .297 \\
\hline V6 & -.082 & .674 & .290 & -.113 & .329 & .140 \\
\hline V7 & .175 & .840 & .077 & .219 & .041 & .126 \\
\hline V8 & .269 & .242 & .730 & .176 & -.087 & .117 \\
\hline V9 & .098 & .040 & .806 & .206 & .165 & -.042 \\
\hline V10 & -.317 & .103 & .576 & .382 & .313 & .080 \\
\hline V11 & .220 & -.003 & .254 & .684 & -.078 & .168 \\
\hline V12 & .072 & .109 & .098 & .737 & .224 & .093 \\
\hline V13 & -.212 & .004 & .157 & .663 & .098 & .444 \\
\hline V16 & .158 & .091 & .230 & .601 & .340 & -.200 \\
\hline V18 & -.038 & .200 & .510 & .528 & .244 & .283 \\
\hline V19 & -.083 & .260 & .300 & .506 & .587 & -.019 \\
\hline V20 & .042 & .304 & .167 & .013 & .731 & .274 \\
\hline V21 & -.061 & .226 & .410 & .168 & .589 & .217 \\
\hline V22 & .188 & -.139 & .354 & .357 & .556 & .196 \\
\hline V23 & .292 & -.007 & .124 & .044 & .751 & .371 \\
\hline V24 & .215 & .123 & -.058 & .212 & .814 & .235 \\
\hline V25 & .176 & .035 & -.074 & .171 & .672 & .281 \\
\hline V26 & .183 & .132 & .195 & -.015 & .313 & .808 \\
\hline V27 & .271 & .279 & -.007 & -.193 & .323 & .710 \\
\hline V28 & .158 & -.128 & .490 & .201 & .112 & .659 \\
\hline V29 & .252 & .024 & .122 & .056 & .240 & .734 \\
\hline V30 & .082 & .520 & -.051 & .284 & .208 & .558 \\
\hline V31 & .142 & .205 & .115 & .333 & .221 & .602 \\
\hline V32 & -.004 & .103 & -.230 & .337 & .166 & .635 \\
\hline $\begin{array}{l}\text { Cumulative } \\
\text { variable explained }\end{array}$ & 8.065 & 15.462 & 26.334 & 39.038 & 54.700 & 70.616 \\
\hline
\end{tabular}


After six dimensional factors were extracted from EFA analysis, the six dimensional CSF are named based on the area of the variables within each dimension. The six dimensional CSF are categorized as:

CSF 1: Laws, regulations \& standards. This encompasses three variables $(\mathrm{V} 1, \mathrm{~V} 2, \mathrm{~V} 3)$ that explained $8.065 \%$ of the variance. The items are all related to the laws, regulations and standards of food safety and food traceability.

CSF 2: Government support \& guidance. This includes two variables (V6, V7) that accounted $7.397 \%$ of the variance. These items deal with the importance of equipment investment and technology support for enterprises implementing systems from government.

CSF 3: Consumer knowledge \& support. This consists of three variables $(\mathrm{V} 8, \mathrm{~V} 9, \mathrm{~V} 10)$ that related to consumers' understanding and support of food traceability implementation. This factor explained $10.872 \%$ of the variance.

CSF 4: Top management, company-wide \& vendor support. This comprises five variables (V11, V12, V13, V16, V18) that explained $12.704 \%$ of the variance. These items explain the importance of support from top stratum and all functional department staff in the company for the system implementation. Besides, the vendors' support is also important. Actually, I consider V18 is better in factor 5 .

CSF 5: Efficient management \& communication. This includes seven variables (V19, V20, V21, V22, V23, V24, V25) that related to system implementation management, administrators' quality and communication between upstream and downstream companies. This factor explains $15.662 \%$ of the variance. 
CSF 6: Information quality \& system quality. This encompasses seven variables (V26, V27,V28,V29,V30,V31,V32) which explained $15.916 \%$ of the variance. The items deal with traceability information quality and system quality.

\subsubsection{Reliability Test}

Reliability is the consistency of the measurement, or the degree to which an instrument measures the same way each time it is used under the same condition with the same subjects. The reliability of a measure indicates the extent to which it is without bias and hence ensures consistent measurement across time and across the various items in the instrument (Sekaran 2003). In short, it is the repeatability of the questionnaire measurement.

In order to ensure that variables comprising each proposed research construct were internally consistent, a reliability assessment was performed using Cronbach's $\alpha$. The higher the Cronbach's $\alpha$ coefficient, the more correlated the items are within the relevant variable. Theoretically, the value of $\alpha$ should be higher than 0.7(Pallant 2005). Other levels have been suggested, however, with respect to this index. Hair et al. (1995) consider that a lower $\alpha$, such as 0.6 , can be acceptable. A generally accepted standard by most scholars is that $\alpha$ higher than 0.8 is considered to be the most reliable, $\alpha$ between 0.6 and 0.8 is considered to be relatively reliable, a lower than 0.6 is considered to be less reliable(Zeng and Huang 2005). The result of analysis is shown in Table 5.10: 
Table 5.10 Reliability Statistics

\begin{tabular}{|c|c|c|}
\hline Variables & Item & Cronbach's $\alpha$ \\
\hline \multirow{3}{*}{ Laws, regulations \& standards } & V 1 & \multirow{3}{*}{0.762} \\
\hline & $\vee 2$ & \\
\hline & V 3 & \\
\hline \multirow{2}{*}{$\begin{array}{l}\text { Government } \\
\text { guidance }\end{array}$} & V 6 & \multirow{2}{*}{0.694} \\
\hline & $\vee 7$ & \\
\hline \multirow{3}{*}{$\begin{array}{l}\text { Consumer knowledge } \\
\& \text { support }\end{array}$} & V 8 & \multirow{3}{*}{0.746} \\
\hline & V 9 & \\
\hline & V 10 & \\
\hline \multirow{5}{*}{$\begin{array}{lr}\text { Top } & \text { management, } \\
\text { company-wide } \quad \& \quad \text { vendor } \\
\text { support }\end{array}$} & V 11 & \multirow{5}{*}{0.802} \\
\hline & V 12 & \\
\hline & V 13 & \\
\hline & V 16 & \\
\hline & V 18 & \\
\hline \multirow{7}{*}{$\begin{array}{l}\text { Efficient management \& } \\
\text { communication }\end{array}$} & V 19 & \multirow{7}{*}{0.893} \\
\hline & V 20 & \\
\hline & $\vee 21$ & \\
\hline & V 22 & \\
\hline & V 23 & \\
\hline & V 24 & \\
\hline & $\vee 25$ & \\
\hline \multirow{7}{*}{$\begin{array}{l}\text { Information quality \& system } \\
\text { quality }\end{array}$} & $\vee 26$ & \multirow{7}{*}{0.886} \\
\hline & $\vee 27$ & \\
\hline & V 28 & \\
\hline & $\vee 29$ & \\
\hline & V 30 & \\
\hline & V 31 & \\
\hline & V 32 & \\
\hline
\end{tabular}

The values of Cronbach's $\alpha$ for all six dimensions of the CSF for the implementation of TS were above the recommended value of 0.6 for exploratory results (Nunnally 1978). Table 5.9 shows that the $\alpha$ coefficients ranged from 0.694 to 0.893 , which indicates that this instrument can be considered relative highly reliable and internally consistent. 


\subsection{Chapter Summary}

This chapter presented the data analysis of interview and questionnaire survey. After the analysis of interview, the measures of TS implementation success were provided. The descriptive analysis of survey data was carried out. The top 15 CSFs are discussed based on the participants' responses (mean). Six dimensional CSF were derived using factor analysis. Next Chapter will propose the CSF framework and discuss the implications of the findings. 


\section{Chapter 6: CSF Framework and Discussion}

\subsection{CSF Framework}

Based on the factor analysis results, a CSF framework is generated as shown in Figure 6.1.

The six dimensional CSF are:

1. laws, regulations \& standards;

2. government support \& guidance;

3. consumer knowledge \& support;

4. top management, company-wide \& vendor support;

5. efficient management \& communication;

6. information quality \& system quality.

TS implementation success measures in the context of Chinese food enterprises include: system users' satisfaction; information users' satisfaction; improved food quality and safety; and enhanced brand and enterprise reputation. 


\begin{tabular}{|c|c|}
\hline Laws, regulations \& standards & TS Implementation \\
\hline Government support \& guidance & $\begin{array}{l}\text { Success In Cninese } \\
\text { Food Enterprises }\end{array}$ \\
\hline Consumer knowledge \& support & System users' satisfaction \\
\hline $\begin{array}{l}\text { Top management, company-wide } \\
\& \text { vendor support }\end{array}$ & $\begin{array}{l}\text { Information } \\
\text { satisfaction }\end{array}$ \\
\hline $\begin{array}{l}\text { Efficient management \& } \\
\text { communication }\end{array}$ & $\begin{array}{l}\text { Enhanced enterprise } \\
\text { brand and reputation }\end{array}$ \\
\hline $\begin{array}{l}\text { Information quality \& system } \\
\text { quality }\end{array}$ & $\begin{array}{l}\text { Improved food quality and } \\
\text { safety }\end{array}$ \\
\hline
\end{tabular}

Figure 6.1 A CSF Framework for Implementing TS in Chinese Food Enterprises

\subsection{EFA Results Interpretation}

This study has identified six dimensional CSF for the implementation of TS. Each dimensional CSF is described as follows:

\subsubsection{Laws, Regulations \& Standards}

Law is "a binding custom or practice of a community: a rule of conduct or action prescribed or formally recognized as binding or enforced by a controlling authority"; Regulation is "a rule or order issued by an executive authority or regulatory agency of a government and having the force of law"; Standard is "something established by authority, custom, or general consent as a model or example" (Merriam Webster). The law plays many functions such as "peacekeeping; checking government power and promoting personal freedom; facilitating planning and the realization of reasonable expectations; promoting economic growth through free 
competition; promoting social justice; and protecting the environment" (Mallor et al. 2007). Quality management has a close relationship with the standardization, and standardization is the basis and foundation of quality management. There are must be a set of standards being used to control and guide the entire process including design, production and use to form the products (including services) quality. The important significance of standardization is to improve the applicability of products, processes and services, reduce and eliminate trade technical barriers, and to promote technical cooperation.

Therefore, laws, regulations and standards play the significant roles in the successful operation of business and society. In this research, perfect laws and regulations relevant with food safety and traceability system implementation, specially and systematically legislate on food business activities from production, processing, storage and sales stages and the corresponding social relations to provide institution ensurance of traceability system implementation; perfect the relevant coding, information technology and logistics technology standards to provide technical basis of traceability system implementation.

\subsubsection{Government Support \& Guidance}

According to Jiang(2007) researched on information systems in the mechanical manufacturers in Kunmin, government directly support and government guidance were ensurance of systems implementation success, and also highlighted that the effectiveness of government guidance was more than government directly support.

Information systems implementations are high investment; high risk and high return projects. Once a project fails to obtain the expected results, it 
will restrict the development of enterprises. In China, food traceability implementation is young, and the enterprises have little knowledge about food traceability and system implementation, however, traceability system application has been an inevitable trend in international trade environment, therefore, government support and guidance are necessary to solve the practical problems.

In this research, government support mainly refers to funding, technology, equipment, etc. and also includes tax concessions. The government should know the difficulties enterprises faced during the systems implementation and which support they can expect from the government to develop effective support strategies and programs which can satisfy actual needs of local enterprises, and also strengthen the supervision of special funds to ensure the effectiveness of financial support.

Government guidance includes policy encouragement and achievement rewards for food enterprises implementing traceability systems; popularizing concepts and relevant knowledge of food traceability to universal popularity; enhancing the education and training to business managers to help them better understanding of tractability international application and traceability systems implementation in enterprises.

\subsubsection{Consumer Knowledge \& Support}

One of the successful system implementation evaluation Indicators is the business benefit. Benefits are based on consumer loyalty and support of products. Therefore, consumer knowledge and support on traceable products are critical for successful implementation of TS in food enterprises. The government and the enterprises must publicize food traceability to consumers to help them better understanding of the food traceability. 
When the consumers realize the benefits of food traceability, they will have willingness to pay for traceable food.

\subsubsection{Top Management, Company-wide \& Vendor Support}

Davenport (1998) has posited that "if the development of an enterprise system is not carefully controlled by management, management may soon find itself under the control of the system". Top management commitment and support referred to the need for management to anticipate any glitches that might be encountered (Motwani et al. 2002). Since the primary responsibility of top management is to provide sufficient financial support and adequate resources for building a successful system, the support of management will ensure that the TS implementation has a high priority within the organization and that it will receive the required resources and attention. Apart from financial support and adequate resources, psychological or behavioral support is also important to the smooth implementation of the project, especially if there is significant resistance from the staff involved.

Since TS are enterprise-wide ISs that within and across all functional areas in an organization, it is imperative to receive support from all functional segments of the organization. Every person and department is responsible/accountable for the overall system and key users from different departments are ensured to commit to the project implementation without being called back to their prior functional job position frequently (Zhang et al. 2005).

Since most food enterprises purchase TS packages from vendors and use outside consultancy service, it is important to get the vendor support. In general, management must make sure that the software vendor provides 
continuous support throughout the implementation. For nice support from vendor, the service response time of the software vendor must be short; the consultants must qualified with knowledge ability in both enterprises' business processes and information technology including TS; and the vendor must participate in TS implementation.

\subsubsection{Efficient Management \& Communication}

An effective project management is essential for a successful TS implementation. For efficient TS management, the system implementation must operate according to schedule strictly; solve the problem facing during the implementation process in time; and besides, there must be an excellent TS implementation team which have sense of responsibility and could obtain education and training of the implementation.

According to Badiru (1988), communication is a prerequisite for the cooperation of employees in the successful implementation of any project. Mendel (1999) stated that strong communication throughout the various stages of the implementation process is essential in allowing employees to understand what is going on in the project, why change is necessary, and how it will benefit the organization. In addition, an effective communication plan will lead to the development of trust and the exchange of information needed for process changes and the acceptance of the new technology (Amoako-Gyampah and Salam 2004). For successful TS implementation, the upstream and downstream enterprises should communicate in time and share information based on the information agreement. There are a number of different communication methods to keep all stakeholders informed of new developments and answering questions about the TS implementation by way of newsletters, focus groups, email and Web-based 
archives.

\subsubsection{Information Quality \& System Quality}

Since TS modules are intricately linked to one another, and TS need offer product information to consumers, the information quality is a major determinant of TS success. The collected/ identified traceability information must be effective, integrity, authenticity and standard.

System quality also affects the system implementation success. Dimensions of system quality include flexibility of the system, reliability, ease of use, usefulness of specific functions, response time (Zhang et al. 2005). In this study, the traceability system must have excellent performance, and the specific function of traceability system can satisfy users' need.

\subsection{Chapter Summary}

This chapter first proposed a CSF framework for implementing TS in Chinese food enterprises, and then discussed EFA results. In next chapter, the conclusion will be presented. 


\section{Chapter 7: Conclusion}

\subsection{Summary of the Study}

This research acknowledges that much research has been carried out on the traceability system development and adoption in food industry, but little research has focused on traceability system implementation success. Since the implementation of TS in China faces many challenges which have created major barriers to the traceability system success, this research aims to identify critical success factors for implementing TS in Chinese food enterprises. More specifically, the study attempts to develop a set of measures of TS implementation success from theoretical and practical point of views, identify CSF and propose a CSF framework for TS implementation success based on empirical findings. To achieve the research objectives, this research adopted both qualitative and quantitative approaches. Extensive literature review was conducted to establish initial understanding of TS implementation success and associated critical success factors. Semi-structured interviews were carried out with six managers to further explore and confirm the measures of TS implementation success and obtain specific important factors affecting TS implementation success. A self-administrated questionnaire was designed to collect primary data of CSF which influence TS implementation success. 124 valid questionnaires were used in the quantitative analysis. Descriptive and factor analysis were conducted using SPSS. A CSF framework for implementing TS in Chinese food enterprises was derived using factor analysis technique. 


\subsection{Key Findings}

The results of this study make valuable contributions to the understanding on the TS implementation success in Chinese food enterprises and the critical success factors affecting implementation success. The main findings of the study can be summarised as follows:

Finding 1 - The establishment of measures of TS implementation success in Chinese food enterprises. Based on the literature review, especially D\&M IS success model and interview data analysis, a set of TS implementation success measures in the context of Chinese food enterprises is proposed. The measures include: system users' (e.g. employees in the company) satisfaction, information users' (e.g. consumers) satisfaction, improved food quality and safety, and enhanced brand and enterprise reputation. These four measures are specific and applicable for TS implementation in food enterprises.

Finding 2 - Based on the descriptive analysis of 124 valid responses, all 32 possible CSF are ranked and listed in Table 5.3. The 32 factors listed in the survey have been considered as important (means ranged from 3.29 to 4.50) by survey participants. For example, the top five ranked factors are "the authenticity of traceability information", "perfect food traceability laws", "perfect food traceability standards", "clear objectives for traceability system implementation" and "policy guidance for enterprises traceability system implementation from government". These top 5 critical success factors highlight the importance of information reliability and quality, laws and standards, implementation objectives, and government support in TS implementation success in Chinese food enterprises. 
Finding 3 - Proposal of CSF framework in Figure 6.1. Six dimensional CSF are derived using factor analysis, which include (1) laws, regulations \& standards; (2) government support \& guidance; (3) consumer knowledge \& support; (4) top management, company-wide \& vendor support; (5) efficient management \& communication; (6) information quality \& system quality. "Top management, company-wide \& vendor support", "efficient management \& communication" and "information quality \& system quality" are frequently discussed in the literatures, but factors in relation to "laws, regulations \& standards" and "government support \& guidance" are hardly mentioned, but they are critical in traceability system implementation in China. Food traceability application in China is still in its primary stage, the application environment is immature, and the food enterprises have little implementation experience. Thus, food traceability system application in China is mainly led by the government. The government should continue to provide not only financial help and support, but also the appropriate laws, regulations, and the standards.

\subsection{Implications}

This study has many implications to TS researchers and practitioners because it identifies the key areas that researchers and food enterprises need to address.

\subsubsection{Research Implications}

The study fills a gap in the TS literature by establishing a set of measures for TS implementation success. The proposal of the success measures serves as a platform for further research on developing and validating items for each measurement. 
The use of factor analysis has unveiled the underlying structure of a large number of CSF in the context of this study and achieved data reduction. The outcome of the CSF framework and a much smaller number of critical success factors would help researchers better understand key areas of CSF and devote their research effort in a more systematic and focused directions.

The CSF framework would be used as a research model for IS researchers to guide their research in different contexts.

The methodological approach adopted in this study can also serves as a helpful example to inspire other IS researchers when investigating inter-organizational IS implementation success in different context.

\subsubsection{Implications for Business Practitioners}

Findings of this study have significant implications for business practitioners.

In China, laws, regulations \& standards and government support \& guidance should be given more attention. Since the Chinese government focuses on food safety issues, laws, regulations, standards and policies have been developed to guide and encourage traceability system applications in food supply chains. The food enterprises should fully understand the policies and follow international and national traceability standards, especially the enterprises which have overseas markets, to achieve the TS implementation success.

Consumer knowledge \& support is another critical factor that influences TS implementation success. The food enterprises should use a variety of 
opportunities for business by publicizing traceability system and traceable food products. These efforts will make consumers understand the features and advantages of the traceable products, enhance purchase intention, and thus indirectly promote the successful implementation of TS.

Information quality is highlighted in this research because the basic characteristics of traceability systems are: identification of units/batches of all ingredients and products, information on when and where they are moved or transformed, a system linking these data (FSA 2002), thus, information authenticity and accuracy have great impact on the TS implementation success.

The research also has implications for TS project management. Once the TS project goes live, enterprises should evaluate its implementation process and result to see what could do to improve their TS implementation impact and business benefit. The TS project is a large program that involves many people, money, and time investment. With correct evaluation of the TS project, enterprises could find where they should spend more time and effort to improve the success.

\subsubsection{Implications for Policy Makers}

One of the objectives of implementing TS in food enterprises in China is ensuring food safety. Food safety is not only related to public life and health, but also to the national economic development and stability. Implementation of food traceability is not only due to the need of protecting public health and economic development, but also the inevitable choice for international trade requirements.

Therefore, laws, regulations and policies related to food safety must be 
appropriate and complete. In the meanwhile, it is necessary to speed up the food traceability system implementation through official enforcement, guidance and incentives. For example, policy makers can provide subsidies, preferential policies for products taxation and promotions and so on for the enterprises which have implemented the traceability system in the whole food supply chain.

\subsection{Research Limitations and Future Research}

One of the limitations of the study is the small sample size used in the interviews and surveys. This is due to the difficulties to communicate with business managers and to persuade them to participate in this investigation. Another reason is that food traceability is a sensitive issue, so business managers were more reluctant to be involved.

Factors affecting TS implementation success are dynamic, complex and abundant, thus any attempt to apply the findings in different context should be cautious and fully aware of the limitations.

TS implementation is not a short-term project lasting only two or three months, but a long-term program which may last for one or several years. In the future research, more stakeholders should be involved in data collection through interviews or case studies. A larger scale of questionnaire surveys could be administrated to enhance the findings. 


\section{Appendices}

\section{Appendix A- CSFs in Literature}

\begin{tabular}{|c|c|c|}
\hline Authors & Objectives & CSFs \\
\hline $\begin{array}{l}\text { Pinto and } \\
\text { Slevin } \\
\text { (1987) }\end{array}$ & $\begin{array}{l}\text { General project } \\
\text { management }\end{array}$ & $\begin{array}{l}\text { Project mission, Top management support, Project schedule / plan, Client } \\
\text { consultation, Personnel recruitment selection and training, Technical tasks, } \\
\text { Client acceptance, Monitoring and feedback, Communication and Trouble } \\
\text { shooting. }\end{array}$ \\
\hline $\begin{array}{l}\text { (Holland } \\
\text { and Light } \\
\text { 1999) }\end{array}$ & $\begin{array}{l}\text { ERP } \\
\text { implementation }\end{array}$ & $\begin{array}{l}\text { Strategic: Legacy systems, Business vision, ERP strategy, Top } \\
\text { management support, Project schedule and plans } \\
\text { Tactical: Client consultation, Personnel, BPC and software configuration, } \\
\text { Client acceptance, Monitoring and feedback, Communication, Trouble } \\
\text { shooting }\end{array}$ \\
\hline $\begin{array}{l}\text { (Sumner } \\
\text { 1999) }\end{array}$ & $\begin{array}{l}\text { ERP } \\
\text { implementation }\end{array}$ & $\begin{array}{l}\text { Top management support, change management and culture, BPR and } \\
\text { minimum customization, effective communication, project management, } \\
\text { monitoring and evaluation of performance, Project champion, ERP } \\
\text { teamwork and composition, }\end{array}$ \\
\hline $\begin{array}{l}\text { (Esteves et } \\
\text { al. 2000) }\end{array}$ & $\begin{array}{l}\text { ERP } \\
\text { implementation }\end{array}$ & $\begin{array}{l}\text { Strategic/organizational: Sustained management support, Effective } \\
\text { organizational change management, Good project scope management, } \\
\text { Adequate project team composition, Comprehensive business process } \\
\text { Reengineering, Adequate project champion role, User involvement and } \\
\text { participation, Trust between partners } \\
\text { Tactical/organizational: Dedicated staff and consultants, Strong } \\
\text { communication inwards and outwards, Formalized project plan/schedule, } \\
\text { Adequate training program, Preventive trouble shooting, Appropriate } \\
\text { usage of consultants, Empowered decision-makers. } \\
\text { Strategic/technological: Adequate ERP implementation strategy, Avoid } \\
\text { customization, Adequate ERP version. } \\
\text { Tactical/technological: Adequate software configuration, and Legacy } \\
\text { systems knowledge. }\end{array}$ \\
\hline $\begin{array}{l}\text { (Shanksa } \\
\text { 2000) }\end{array}$ & $\begin{array}{l}\text { ERP } \\
\text { implementation }\end{array}$ & $\begin{array}{l}\text { Management support, Champion, Balanced team, Commitment to change, } \\
\text { Vanilla ERP, Empowered decision makers, Best people full-time, } \\
\text { Deliverable dates, Definition of scope and goals, and smaller scope. }\end{array}$ \\
\hline $\begin{array}{l}\text { (Kim and } \\
\text { Peterson } \\
\text { 2000/2001) }\end{array}$ & $\begin{array}{l}\text { Information } \\
\text { system(from } \\
\text { developers' } \\
\text { perceptions) }\end{array}$ & $\begin{array}{l}\text { Management/user input, Project management, Characteristics of the } \\
\text { project leader, Methodology, Characteristics of the team members }\end{array}$ \\
\hline $\begin{array}{l}\text { (Nah and } \\
\text { Lau 2001) }\end{array}$ & $\begin{array}{l}\text { ERP } \\
\text { implementation }\end{array}$ & $\begin{array}{l}\text { Top management support, Business plan and vision, Effective } \\
\text { communication, Project management, Change management program and } \\
\text { culture, Project champion, Business process reengineering (BPR) and } \\
\text { minimum customization, ERP team \& composition, Appropriate business \& }\end{array}$ \\
\hline
\end{tabular}




\begin{tabular}{|c|c|c|}
\hline & & $\begin{array}{l}\text { IT legacy system, Software development, testing and troubleshooting, and } \\
\text { Monitoring and evaluation of performance. }\end{array}$ \\
\hline $\begin{array}{l}\text { (Akkermans } \\
\text { and Helden } \\
\text { 2002) }\end{array}$ & $\begin{array}{l}\text { ERP } \\
\text { implementation }\end{array}$ & $\begin{array}{l}\text { Top management support, Project team competence, Interdepartmental } \\
\text { cooperation, Clear goals and objectives, Project management , } \\
\text { Interdepartmental communication, Management of expectations Project } \\
\text { champion, Vendor support, Careful package selection, Data analysis and } \\
\text { conversion, Dedicated resources, Steering committee, User training, } \\
\text { Education on new business processes, BPR Minimal customization , } \\
\text { Architecture choices, Change management, Vendor partnership, Vendor's } \\
\text { tools, Use of consultants. }\end{array}$ \\
\hline $\begin{array}{l}\text { (Zhang et } \\
\text { al. 2002) }\end{array}$ & $\begin{array}{l}\text { ERP } \\
\text { implementation }\end{array}$ & $\begin{array}{l}\text { Organizational-environments: Top management support, Business } \\
\text { process reengineering, Company-wide support, Effective project } \\
\text { management } \\
\text { People characteristics: Education \& training, User involvement, } \\
\text { Suitability of software \& hardware } \\
\text { Technical problems: Data accuracy } \\
\text { ERP Vendor support: Vendor support } \\
\text { Cultural impact: Chinese organization culture }\end{array}$ \\
\hline $\begin{array}{l}\text { (Al-Mashar } \\
\text { et al. 2003) }\end{array}$ & $\begin{array}{l}\text { ERP } \\
\text { implementation }\end{array}$ & $\begin{array}{l}\text { Setting-up: Management and leadership, Visioning and planning. } \\
\text { Deployment: ERP package selection, Process management, Training and } \\
\text { education, Communication, Project management, Legacy systems } \\
\text { management, System integration, System testing, Cultural and structural } \\
\text { changes. } \\
\text { Evaluation: Performance evaluation and management. }\end{array}$ \\
\hline $\begin{array}{l}\text { (Croteau } \\
\text { and } \mathrm{Li} \\
\text { 2003) }\end{array}$ & $\begin{array}{l}\text { CRM } \\
\text { Technological } \\
\text { Initiatives }\end{array}$ & $\begin{array}{l}\text { Operational perceived benefits, Strategic perceived benefits, Top } \\
\text { management support, Technological readiness, Knowledge management } \\
\text { capabilities }\end{array}$ \\
\hline $\begin{array}{l}\text { (Umblea et } \\
\text { al. 2003) }\end{array}$ & $\begin{array}{l}\text { ERP } \\
\text { implementation }\end{array}$ & $\begin{array}{l}\text { Clear understanding of strategic goals, Commitment by top management, } \\
\text { Organizational change management, Excellent project management, A } \\
\text { great implementation team, Data accuracy, Extensive education and } \\
\text { training, Focused performance measures, Multi-site issues. }\end{array}$ \\
\hline 004) & $\begin{array}{l}\text { ERP } \\
\text { implementation } \\
\text { in China }\end{array}$ & $\begin{array}{l}\text { Organize efficient project management team, Face the problem in the } \\
\text { implementation process, Choose the appropriate ERP vendor, and Get the } \\
\text { firm support from top management }\end{array}$ \\
\hline $\begin{array}{l}(\mathrm{LOH} \quad \text { and } \\
\mathrm{KOH} 2004)\end{array}$ & $\begin{array}{l}\text { ERP } \\
\text { Implementation } \\
\text { in SMEs }\end{array}$ & $\begin{array}{l}\text { Chartering phase: Project champion, Project management, Business plan } \\
\text { and vision, Top management support, Effective communication, ERP } \\
\text { teamwork and composition } \\
\text { Project phase: BPR and minimum customization } \\
\text { Shakedown phase: Change management program and culture, Software } \\
\text { development, testing and troubleshooting } \\
\text { Onward \& upward phase: Monitoring and evaluation of performance }\end{array}$ \\
\hline $\begin{array}{l}\text { (Ngai et al. } \\
\text { 2004) }\end{array}$ & $\begin{array}{l}\text { Web-based } \\
\text { supply-chain } \\
\text { management }\end{array}$ & $\begin{array}{l}\text { Communication, Top management commitment, Data security, Training } \\
\text { and education, Hardware and software reliability }\end{array}$ \\
\hline
\end{tabular}




\begin{tabular}{|c|c|c|}
\hline & systems & \\
\hline $\begin{array}{l}\text { (Somers } \\
\text { and Nelson } \\
\text { 2004) }\end{array}$ & $\begin{array}{l}\text { ERP } \\
\text { implementation }\end{array}$ & $\begin{array}{l}\text { Key Players: Top management, Project champion, Steering committee, } \\
\text { Vendor-customer, partnerships, Vendors' tools, Vendor support, } \\
\text { Implementation consultants, Project team } \\
\text { Key Activities: User training and education, Management of expectations, } \\
\text { Careful selection of the appropriate package, Project management, } \\
\text { Customization, Data analysis and conversion, Change management, } \\
\text { Establishing clear goals and objectives, Business process reengineering, } \\
\text { Defining the architecture, Dedicating resources, Education on new } \\
\text { business processes, Interdepartmental communication, Interdepartmental } \\
\text { cooperation, }\end{array}$ \\
\hline $\begin{array}{l}\text { (Bhatti } \\
2005)\end{array}$ & $\begin{array}{l}\text { ERP } \\
\text { implementation }\end{array}$ & $\begin{array}{l}\text { Project Management, Process redesign, User training, Technological, } \\
\text { infrastructure, Change management, Risk Management, Communication, } \\
\text { Team work, User involvement, Use of consultant, Clear goals and } \\
\text { objective, Top management support. }\end{array}$ \\
\hline $\begin{array}{l}\text { (Dubelaar } \\
\text { et al. 2005) }\end{array}$ & $\begin{array}{l}\text { B2C E-business } \\
\text { adoption }\end{array}$ & $\begin{array}{l}\text { Combining e-business knowledge, value proposition and delivery } \\
\text { measurement, Customer satisfaction and retention, Monitoring internal } \\
\text { processes and computer activity, Building trust }\end{array}$ \\
\hline (Min 2005) & $\begin{array}{l}\text { ERP } \\
\text { implementation } \\
\text { in China }\end{array}$ & $\begin{array}{l}\text { Top management support, Business process reengineering, Project } \\
\text { management, Change management and External professional support }\end{array}$ \\
\hline $\begin{array}{l}\text { (Salmeron } \\
\text { and Herrero } \\
\text { 2005) }\end{array}$ & EIS & $\begin{array}{l}\text { Human resources: User involvement, Competent and balanced EIS staff, } \\
\text { Executive sponsor's support } \\
\text { Information and technology: Right information needs, Suitable hard/soft } \\
\text { System interaction :Flexible sensitive system, Speedy prototype } \\
\text { development, Tailored system }\end{array}$ \\
\hline $\begin{array}{l}\text { (Zhang et } \\
\text { al. 2005) }\end{array}$ & $\begin{array}{l}\text { ERP } \\
\text { implementation }\end{array}$ & $\begin{array}{l}\text { Organizational environments: Top management support, Company-wide } \\
\text { support, Business process reengineering, Effective project management, } \\
\text { organization culture } \\
\text { User environment: Education \& training, User involvement, User } \\
\text { characteristics } \\
\text { System environment: ERP software Suitability, Information quality, } \\
\text { System quality } \\
\text { ERP Vendor environment: ERP vendor quality }\end{array}$ \\
\hline (Guo 2006) & $\begin{array}{l}\text { ERP } \\
\text { implementation } \\
\text { in China }\end{array}$ & $\begin{array}{l}\text { Leadership factors, Process management, Change management and } \\
\text { Success evaluation }\end{array}$ \\
\hline $\begin{array}{l}\text { (Lu et al. } \\
2006)\end{array}$ & $\begin{array}{l}\text { Inter-organizatio } \\
\text { nal information } \\
\text { system }\end{array}$ & $\begin{array}{l}\text { Decision motivation: Strong internal and external commitment, Shared } \\
\text { motivation and vision } \\
\text { Implementation process: Cross-organizational implementation team, } \\
\text { High integration with internal information systems, Inter-organizational } \\
\text { business process re-engineering } \\
\text { Infrastructure condition: Advanced legacy information system and } \\
\text { infrastructure, Shared industry standards }\end{array}$ \\
\hline
\end{tabular}




\begin{tabular}{|c|c|c|}
\hline $\begin{array}{l}\text { (Nah and } \\
\text { Delgado } \\
\text { 2006) }\end{array}$ & $\begin{array}{l}\text { ERP } \\
\text { implementation } \\
\text { and upgrade }\end{array}$ & $\begin{array}{l}\text { Project phase: ERP team composition, skills and compensation, Project } \\
\text { management, System analysis, selection and technical implementation } \\
\text { Chartering phase: Business plan and vision, Top management support } \\
\text { and championship } \\
\text { Project and shakedown phases: Communication, Change management }\end{array}$ \\
\hline (Soja 2006) & $\begin{array}{l}\text { ERP } \\
\text { implementation }\end{array}$ & $\begin{array}{l}\text { Participants: Project Manager, Team Composition, Team Involvement, } \\
\text { Motivation System, cooperation with supplier. } \\
\text { Top management involvement: Top Management Support, Top } \\
\text { Management, Awareness, Top Management Participation. } \\
\text { Project definition and organization: Linking with strategy, } \\
\text { implementation, goals, detailed schedule, Pre-implementation analysis, } \\
\text { organizational change, Monitoring and feedback, implementation } \\
\text { promotion, fast effects, appropriate trainings. } \\
\text { Project status: Investment plan, Project Team Empowerment, Financial } \\
\text { Budget, work time budget, IT infrastructure. } \\
\text { Information systems: System Reliability, Minimal customization, Legacy } \\
\text { system and implementation Experience. }\end{array}$ \\
\hline $\begin{array}{l}\text { (Finney and } \\
\text { Corbett } \\
2007 \text { ) }\end{array}$ & $\begin{array}{l}\text { ERP } \\
\text { implementation }\end{array}$ & $\begin{array}{l}\text { Strategic: Top management commitment and support, Visioning and } \\
\text { planning, Build a business case, Project champion, Implementation } \\
\text { strategy and timeframe, Vanilla ERP, Project management, Change } \\
\text { management, Managing cultural change. } \\
\text { Tactical: Balanced team, Project team: the best and brightest, } \\
\text { Communication plan, Empowered decision makers, Team morale and } \\
\text { motivation, Project cost planning and management, BPR and software } \\
\text { configuration, Legacy system consideration, IT infrastructure, Client } \\
\text { consultation, Selection of ERP, Consultant selection and relationship, } \\
\text { Training and job redesign, Troubleshooting/crises management, Data } \\
\text { conversion and integrity, System testing, Post-implementation evaluation. }\end{array}$ \\
\hline $\begin{array}{l}\text { (García-Sá } \\
\text { nchez and } \\
\text { Pérez-Bern } \\
\text { al 2007) }\end{array}$ & $\begin{array}{l}\text { ERP system } \\
\text { implementation } \\
\text { in Mexican } \\
\text { enterprises }\end{array}$ & $\begin{array}{l}\text { Human factors: Teamwork composition(3), Communication(4), Project } \\
\text { champion(9), End user involvement(10) } \\
\text { Technological factors: Project management(2), ERP system selection(6), } \\
\text { Training and support for users(8), Tests and problem solution(12), To } \\
\text { facilitate changes in the organizational structure, in the "legacy systems" } \\
\text { and in the IT infrastructure(13) } \\
\text { Organizational factors: Top management support(1), Business process } \\
\text { reengineering(5), Having external consultants(7), Change management } \\
\text { plan(11), Vision statement and adequate business plan(14) }\end{array}$ \\
\hline $\begin{array}{l}\text { (Huang } \\
2007 \text { ) }\end{array}$ & $\begin{array}{l}\text { Workflow } \\
\text { Management } \\
\text { System } \\
\text { Implementation } \\
\text { in manufacturing } \\
\text { enterprise in } \\
\text { supply chain }\end{array}$ & $\begin{array}{l}\text { Clear and accurate motive and goals, Correct attitude, high support and } \\
\text { active operate for the internal changes, Accurate cost estimates and } \\
\text { sufficient relevant resources, Fully trust and cooperation between } \\
\text { upstream and downstream enterprises on supply chain, The concern about } \\
\text { the underlying business processes and real business activities, and } \\
\text { Establishment of a scientific and reliable performance appraisal system }\end{array}$ \\
\hline
\end{tabular}




\begin{tabular}{|c|c|c|}
\hline $\begin{array}{l}\text { (Jiang } \\
\text { 2007) }\end{array}$ & $\begin{array}{l}\text { IS } \\
\text { implementation } \\
\text { in the mechanical } \\
\text { manufacturers in } \\
\text { Kunming }\end{array}$ & $\begin{array}{l}\text { Top management support, project management, business process } \\
\text { management, direct support from government, government guidance and } \\
\text { the external environment. }\end{array}$ \\
\hline $\begin{array}{l}\text { (Remus } \\
\text { 2007) }\end{array}$ & $\begin{array}{l}\text { ERP } \\
\text { implementation }\end{array}$ & $\begin{array}{l}\text { Strategic/organizational: Top management support, Clear goals and } \\
\text { objective, Management of expectations, Project champion, Dedicated } \\
\text { resources, Use of steering committee, Business Process Reengineering, } \\
\text { Change management, Partnership with vendor. } \\
\text { Tactical/organizational: User training on software, Project management, } \\
\text { Interdepartmental communication, Interdepartmental cooperation, Team } \\
\text { competencies and skills, Education on new business, Processes, Vendor } \\
\text { support. } \\
\text { Strategic/technological: Careful package selection, and Minimal } \\
\text { customization } \\
\text { Tactical/technological: Data analysis \& conversion, Architecture choice, } \\
\text { and Use of vendors' tools. }\end{array}$ \\
\hline$(\mathrm{Re}$ & $\begin{array}{l}\text { B2B E-business } \\
\text { implementation } \\
\text { in SMEs }\end{array}$ & $\begin{array}{l}\text { Leadership attention, Goal programming, Third-party promotion, } \\
\text { Outsourcing, Staff training, Management systems and functions }\end{array}$ \\
\hline $\begin{array}{l}\text { (Sun et al. } \\
2007)\end{array}$ & $\begin{array}{l}\text { ERP } \\
\text { implementation } \\
\text { in China }\end{array}$ & $\begin{array}{l}\text { Top support and user involvement, Education and training, Senior } \\
\text { management support, IT support }\end{array}$ \\
\hline $\begin{array}{l}\text { (Yeoh et al. } \\
\text { 2007) }\end{array}$ & $\begin{array}{l}\text { Business } \\
\text { intelligence } \\
\text { system } \\
\text { implementation }\end{array}$ & $\begin{array}{l}\text { Management support \& championship: Committed top management } \\
\text { support, Adequate resources are provided, A high-level champion from } \\
\text { business side } \\
\text { User-oriented change management: Formal user involvement } \\
\text { throughout he lifecycle, Formal education, training and support are in place } \\
\text { Business vision: Strategic BI vision that is integrated with company } \\
\text { initiatives, Well-established business case } \\
\text { Project planning: Project scope is clearly defined, Adoption of } \\
\text { incremental delivery approach, Project scheduled to deliver quick wins } \\
\text { Team skills \& composition: Team possess the right mix of skills, Use of } \\
\text { external consultant at early stage, Committed expertise from business } \\
\text { domain } \\
\text { Infrastructure-related issues: Stable sources systems are in place, } \\
\text { Establishment of a strategic, scalable and extensible technical framework, } \\
\text { Prototype is used as proof of } \\
\text { Data-related issues: High quality of data at source systems, Information } \\
\text { area readiness, Business-led establishment of common measures and } \\
\text { classifications, Sustainable dimensional and metadata model, } \\
\text { Business-led data governance }\end{array}$ \\
\hline $\begin{array}{l}\text { (Al-Fawaz } \\
\text { et al. 2008) }\end{array}$ & $\begin{array}{l}\text { ERP } \\
\text { implementation }\end{array}$ & $\begin{array}{l}\text { Top Management Support, Business Plan and Vision, Re-engineering } \\
\text { Business, Process, Project Management and Project Champion, }\end{array}$ \\
\hline
\end{tabular}




\begin{tabular}{|c|c|c|}
\hline & & $\begin{array}{l}\text { Teamwork and, Composition, ERP System Selection, User Involvement, } \\
\text { Education and Training. }\end{array}$ \\
\hline $\begin{array}{l}\text { (Bradley } \\
\text { 2008) }\end{array}$ & $\begin{array}{l}\text { ERP } \\
\text { implementation } \\
\text { (Management } \\
\text { based) }\end{array}$ & $\begin{array}{l}\text { Project with full time project manager, Experience of project manager, } \\
\text { Training quality and quantity, Use of consultant, Champion, Management } \\
\text { effectiveness/user resistance, Steering committee }\end{array}$ \\
\hline $\begin{array}{l}\text { (Chetc } \\
\text { 2008) }\end{array}$ & $\begin{array}{l}\text { ERP } \\
\text { implementation }\end{array}$ & $\begin{array}{l}\text { Strategic/organizational: Top Management Commitment \& Support, } \\
\text { Building a Business Case, Vision and Planning, Project Champion, Project } \\
\text { Management, Change Management, Implementation Strategy, Managing } \\
\text { Cultural Change, Management of Expectations. } \\
\text { Tactical/organizational: Project Team Balance, Competence, Motivation } \\
\text { and Empowerment, Communication Plan, BPR, Consultants Selection and } \\
\text { Relationship, Continuous Training and Education on new business } \\
\text { processes, Post-Implementation Evaluation, Vendor Support, Partnership } \\
\text { and Tools. } \\
\text { Strategic/technological: Vanilla ERP, ERP Package Selection, and } \\
\text { Legacy, System Consideration. } \\
\text { Tactical/technological: IT Infrastructure and Architectural choices, Data } \\
\text { Conversion and Integrity, Systems Testing \& Troubleshooting, Package } \\
\text { Configuration. }\end{array}$ \\
\hline $\begin{array}{l}\text { (Chow and } \\
\text { Cao 2008) }\end{array}$ & $\begin{array}{l}\text { Software } \\
\text { development } \\
\text { project }\end{array}$ & $\begin{array}{l}\text { Organizational factors: Management commitment, Organizational } \\
\text { environment, Team environment } \\
\text { People factors: Team capability, Customer involvement } \\
\text { Process factors: Project management process, Project definition process } \\
\text { Technical factors: Agile software techniques, Delivery strategy } \\
\text { Project factors: Project nature, Project type, Project schedule }\end{array}$ \\
\hline $\begin{array}{l}\text { (Zhai et al. } \\
\text { 2008) }\end{array}$ & IS/I & $\begin{array}{l}\text { Factors related to project stakeholders: Top Management, Project } \\
\text { Manager, Project Members, Users } \\
\text { Project support factors: Communication Management, Relationship } \\
\text { Management } \\
\text { Factors related to project life cycle: Project Definition, Project Plan, } \\
\text { Project Control And Change Management }\end{array}$ \\
\hline (Dan & $\begin{array}{l}\text { ERP } \\
\text { implementation } \\
\text { in indian SME's }\end{array}$ & $\begin{array}{l}\text { From extremely important to important: Top management support, Goal } \\
\text { \& objective, User knowledge, Project champion, Project team competency, } \\
\text { Improve work efficiency, Scalability \& scope }\end{array}$ \\
\hline $\begin{array}{l}\text { (Rabaa'i } \\
\text { 2009) }\end{array}$ & $\begin{array}{l}\text { ERP } \\
\text { the system at } \\
\text { education sector }\end{array}$ & $\begin{array}{l}\text { From extremely important to important: Top management commitment } \\
\text { and support, Change management, Project management, BRP and } \\
\text { system's customization, Training, ERP team composition, Visioning and } \\
\text { planning, Consultant selection and relationship, Communication plan, ERP } \\
\text { systems selection, ERP systems integration, Post-implementation } \\
\text { evaluation }\end{array}$ \\
\hline $\begin{array}{l}\text { (Doom et } \\
\text { al. 2010) }\end{array}$ & $\begin{array}{l}\text { ERP } \\
\text { implementation } \\
\text { in Belgian SMEs }\end{array}$ & $\begin{array}{l}\text { A clear vision of the strategic goals of the ERP implementation, Senior } \\
\text { management support ,Active user involvement, A suitable corporate } \\
\text { culture that is open to change, Internal communication on the ERP }\end{array}$ \\
\hline
\end{tabular}




\begin{tabular}{|c|c|c|}
\hline & & $\begin{array}{l}\text { project(both before and during the project), Proper management of the } \\
\text { ERP supplier, A formalized project approach and methodology, A focus on } \\
\text { user requirements, The use of external consultants, User training(both on } \\
\text { technical aspects and on business aspects, oriented towards practice), } \\
\text { Proper project planning, phasing and follow-up, Proper project } \\
\text { management, A project team(composed of a mix of users, i.e. internal } \\
\text { technical and business experts and external consultant) }\end{array}$ \\
\hline $\begin{array}{l}\text { (Hsu } \\
2010)\end{array}$ & $\begin{array}{l}\text { Airline safety } \\
\text { management } \\
\text { system }\end{array}$ & $\begin{array}{l}\text { Organization: Safety policy(1), Safety objective and goals(6), } \\
\text { Performance measurement/baseline(10), Organizational structure, } \\
\text { accountability and responsibility(11), Management commitment(13) } \\
\text { Documentation: Identification and maintenance of applicable } \\
\text { regulations(5), } \\
\text { Risk management: Hazard identification(7), Safety analysis capability(8), } \\
\text { Risk assessment(9), Recommending actions based on safety } \\
\text { evaluation(12) } \\
\text { Safety promotion: Safety culture(2), Communication(3), } \\
\text { Training-awareness and competence(4) }\end{array}$ \\
\hline
\end{tabular}




\title{
Appendix B- Participant Information Sheet (English Version)
}

\author{
1. Project Title \\ Critical success factors for implementing traceability systems in Chinese food enterprises
}

\section{Invitation Paragraph}

You are being invited to take part in a research project. Before you decide to participate it is important for you to understand why the research is being done and what it will involve. Please take time to read the following information carefully and discuss it with others if you wish. Ask if anything is unclear or if you would like more information.

\section{Purpose of Project}

This study aims to identify critical success factors for implementing Traceability Systems (TS) in Chinese food enterprises. Specifically, obtain measures of successful TS implementation; build a CSF framework for implementing TS in Chinese food enterprises.

\section{Why have I been chosen? Do I have to take part?}

You are been chosen because you are the employee in the food enterprise which has implemented TS and also you are the officer in charge of the implementation or you are a system implementation commissioner. The participation is voluntary and you may discontinue participation at any time.

\section{What will happen to me if I take part?}

Your involvement in the study would be to take part in a semi-structured interview where we discuss: your understanding of what is TS implementation success and its critical success factors. This can be taken via face to face or telephone. The interview will last approximately 45 minutes depending on how much time you have available, and how much information you want to share. I will record the interviews with your permission.

6. What are the possible disadvantages and risks of participation?

Involvement in the study will not impact on the individual. The information gained will NOT be used for any other purpose than the study and individuals will not be named.

\section{Will my participation be kept confidential?}

All information that is collected about you during the course of the research will be kept strictly confidential. The only contact information required will be either a mobile telephone number or email address. All interview recordings will be destroyed at the end of the research. Your name or any contact details will not be recorded on the interview transcripts. In addition, any details which potentially could identify you will also be removed or changed. Your participation in this study will not be discussed with other interviewees. Your name will be changed in the research and I will ensure that your involvement remains entirely confidential and anonymous. I am not under an obligation to 
report anything you say that could be defined as illegal. However, disclosure may be required if you were to say something that potentially indicated that you or someone else was at risk of harm. If you said something of this type I would indicate this and you could then choose whether or not to continue the discussion. We would also discuss what the next steps would be.

8. What will happen to the results of the research project?

The results of the study will be used in my MSc by research thesis. The material will be presented at academic and professional conferences or in academic journals. Anonymity and confidentiality will still be in place in all cases..

9. What if there is a problem?

If you would like to provide feedback or have a concern about any aspect of this study, please speak to Meiyin Miao at Business and Management Research Institute in University of Bedfordshire for Involvement. Remember you may withdraw from this study at any time.

\section{Contact details}

If you would like further information about this research, please contact:

Meiyin Miao, project researcher

Email: miaomeiyin@yahoo.cn / Meiyin.Miao@beds.ac.uk

Tel: 01582743138

Thank you for reading this information sheet, and if it is possible, participating in the study. 


\section{Appendix C- Interview Outline (English Version)}

Dear Sir/Madam, thank you for participating our interview!

Interviewee: Position: Company: How long for working with information system implementation: Interview Date: Recorder:

\section{Section One: Overview of Implementation of Traceability System in Company}

1. How many employees in the entire company? How many employees who are relative with the implementation of traceability system (monitoring, operation and management)? 2. When did your company start implementing traceability system? Who developed the system? Who fund the system?

3. What do you think about the reason why the company implements traceability system?

4. Has the company's economic benefit changed after its implementation of traceability system?

5. What are the traceable products in the company? Are products in abroad markets beside in China?

6. What is the change of product price after the implementation? What does traceability costs include?

7. What are the education backgrounds of employees related to system implementation? Can they solve the problem on their own?

8. What are the difficulties or problems and the cause during the system implementation process?

9. What support would you like to receive from the government for implementing system?

\section{Section Two: Traceability Implementation Success in Food Company}

10. What do you think of the traceability system implementation success?

11. In your opinion, what are the main aspects (measures) for the traceability system success?

Section Three: Critical Success Factors for Implementing Traceability System in Food Company

12. In your opinion, what are critical success factors for implementing traceability system in the company? (Including internal and external factors and what is your view on these factors?) 


\section{Appendix D- Cover Letter (English Version)}

Dear Respondents,

I am inviting you to participate in a research project to study factors affecting traceability system implementation. The study aims to identify the critical success factors for implementing traceability system in Chinese food enterprises. Along with this letter is a short questionnaire. Please look over the questionnaire and it will take you 5 10 minutes to complete.

The results of this project will contribute to the food enterprises which have implemented traceability systems. Through your participation I hope to understand the main factors which can affect traceability system implementation success. It is hoped that the results of the survey will be useful for development of traceability system implementation.

I guarantee that the questionnaire is totally anonymous so no individual's responses can or will be identified. I promise not to share any information that identifies you with anyone outside my research group.

Please read each question carefully, and select the response that best reflects your reaction to the question or item. There is no right or wrong answers; we are interested in your own personal perspectives, whatever they are.

Your participation is voluntary, but I really hope you will help complete the questionnaire and return it. Regardless of whether you choose to participate, please let me know if you would like a summary of my findings. If you have any questions or concerns about completing the questionnaire or about being in this study, you may contact me at nmiaomeiyin@yahoo.cm. The Business School at the University of Bedfordshire has approved this study. If you have any concerns about your rights as a participant in this study you may contact the Research Office of Business School.

Thank you very much for your Participation!

Sincerely,

Meiyin Miao 


\section{Appendix E- Questionnaire (English Version)}

Note: In this study, the measures of traceability system implementation success in the context of Chinese food enterprises include: system users' (e.g. employees in the company) satisfaction, information users' (e.g. consumers) satisfaction, improved food quality and safety, and enhanced brand and enterprise reputation.

The critical success factor refers to those factors which have important influence on the successful outcome during the traceability system implementation process, and these factors represent possible problems or areas which need companies to focus on and which make great guidance for the enterprises implementing traceability systems.

\section{Section One: Critical Success Factors}

Here are some items designed based on above definitions. Please tick " $\checkmark$ " based on your personal view in the relative cell in following scale: 1: Non important; 2: little important; 3 : important; 4: very important; 5: extremely important (5-point scale)

\begin{tabular}{|c|c|c|c|c|c|}
\hline \multirow{2}{*}{ Factors } & \multicolumn{5}{|c|}{ Importance } \\
\hline & 1 & 2 & 3 & 4 & 5 \\
\hline \multicolumn{6}{|l|}{ 1. Perfect food traceability regulations } \\
\hline \multicolumn{6}{|l|}{ 2. Perfect food traceability laws } \\
\hline \multicolumn{6}{|l|}{ 3. Perfect food traceability standards } \\
\hline \multicolumn{6}{|l|}{$\begin{array}{l}\text { 4. Policy guidance for enterprises implementing systems from } \\
\text { government }\end{array}$} \\
\hline \multicolumn{6}{|l|}{$\begin{array}{l}\text { 5. Funding for traceability system implementation from } \\
\text { government }\end{array}$} \\
\hline \multicolumn{6}{|l|}{$\begin{array}{l}\text { 6. Equipment investment for traceability system implementation } \\
\text { from government }\end{array}$} \\
\hline \multicolumn{6}{|l|}{$\begin{array}{l}\text { 7. Technology support for traceability system implementation } \\
\text { from government }\end{array}$} \\
\hline \multicolumn{6}{|l|}{ 8. Food traceability publicity to consumers from the government } \\
\hline \multicolumn{6}{|l|}{ 9. Willingness to pay from consumer for traceable food } \\
\hline \multicolumn{6}{|l|}{ 10. Full understanding of food traceability from consumers } \\
\hline \multicolumn{6}{|l|}{$\begin{array}{l}\text { 11. Vendors offer continuous support during the whole system } \\
\text { implementation process }\end{array}$} \\
\hline \multicolumn{6}{|l|}{$\begin{array}{l}\text { 12. Support for traceability system implementation from all } \\
\text { functional departments in enterprises }\end{array}$} \\
\hline \multicolumn{6}{|l|}{ 13. System operation and maintenance investment } \\
\hline $\begin{array}{l}\text { 14. Traceability system implementation being taken into } \\
\text { corporate strategy by top management }\end{array}$ & & & & & \\
\hline
\end{tabular}




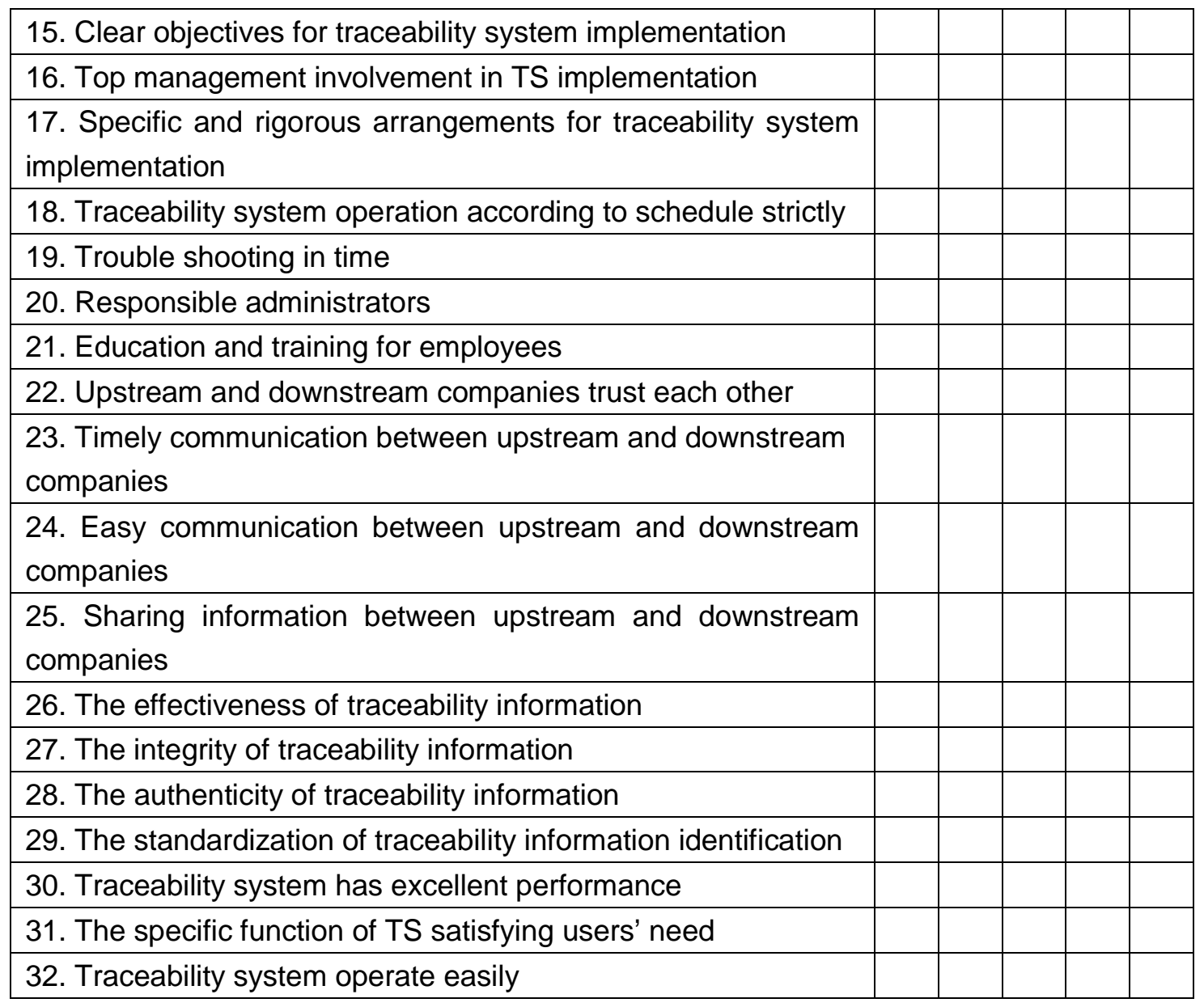

Is there any success factor that you consider important but not in this questionnaire? If so, please write in the following line.

\section{Section Two: Your Personal Basic Information}

Note: please tick ' $\checkmark$ 'in 【】 in front of the corresponding options based on your personal view.

1. Your current position:
【】(1) General manager
【】(2) Department manager
【】(3) Project manager
【 】(4) Manager assistant
【】(5) Expert
】(6) System implementation commissioner
【】(7) System operator
【】(8) Others (Please fill positions on the line)

2. How long have you participated in (or monitor or research on) information system (including traceability system) implementation?
【】(1) In 1 year
【】(2) 2-3 years
【】(3) 4-6 years
【】(4) over 7 years

3. Your education background
【】(1) Junior high school and lower
【】(2) High School
【】(3) Junior college
I (4) Undergraduate and higher 
4. Have you got the education or training about implementing traceability in food enterprises?
【】(1) Yes
【】(2) No

Thank You Very Much for Your Participation!

Do you need the report of this survey? 【】Yes 【】No

If you choose 'Yes', please provide your post address on the line 


\section{Sources of Factors in Questionnaire}

\begin{tabular}{|c|c|}
\hline Factors & Sources \\
\hline 1. Perfect food traceability regulations & (Zan et al. 2007)/Interview \\
\hline 2. Perfect food traceability laws & (Zan et al. 2007)/Interview \\
\hline 3. Perfect food traceability standards & (Zan et al. 2007)/Interview \\
\hline $\begin{array}{l}\text { 4. Policy guidance for enterprises implementing systems } \\
\text { from government }\end{array}$ & (Jiang 2007)/Interview \\
\hline $\begin{array}{l}\text { 5. Funding for traceability system implementation from } \\
\text { government }\end{array}$ & (Jiang 2007)/Interview \\
\hline $\begin{array}{l}\text { 6. Equipment investment for traceability } \\
\text { implementation from government }\end{array}$ & Interview \\
\hline $\begin{array}{l}\text { 7. Technology support for traceability system implementation } \\
\text { from government }\end{array}$ & (CCSFA 2007) \\
\hline $\begin{array}{l}\text { 8. Food traceability publicity to consumers from the } \\
\text { government }\end{array}$ & $\begin{array}{l}\text { (Jiang 2007; } \mathrm{Xu} \text { and } \mathrm{Wu} \\
\text { 2008)/interview }\end{array}$ \\
\hline 9. Willingness to pay from consumer for traceable food & (Han and Qiao 2009) \\
\hline 10. Full understanding of food traceability from consumers & Interview \\
\hline $\begin{array}{l}\text { 11. Vendors offer continuous support during the whole } \\
\text { system implementation process }\end{array}$ & (Chetcuti 2008) \\
\hline $\begin{array}{l}\text { 12. Support for traceability system implementation from all } \\
\text { functional departments in enterprises }\end{array}$ & (Zhang et al. 2002) \\
\hline 13. System operation and maintenance investment & (CCSFA 2007) \\
\hline $\begin{array}{l}\text { 14. Traceability system implementation being taken into } \\
\text { corporate strategy by top management }\end{array}$ & (Lee and Kim 2007) \\
\hline 15. Clear objectives for traceability system implementation & $\begin{array}{l}\text { (Doom et al. 2010; Nah and } \\
\text { Delgado 2006) }\end{array}$ \\
\hline 16. Top management involvement in TS implementation & $\begin{array}{l}\text { (Lee and Kim 2007; Ngai et al. } \\
\text { 2004)/Interview }\end{array}$ \\
\hline $\begin{array}{l}\text { 17. Specific and rigorous arrangements for traceability } \\
\text { system implementation }\end{array}$ & (Nah and Delgado 2006) \\
\hline $\begin{array}{l}\text { 18. Traceability system operation according to schedule } \\
\text { strictly }\end{array}$ & (Nah and Delgado 2006) \\
\hline 19. Trouble shooting in time & (Nah and Delgado 2006) \\
\hline 20. Responsible administrators & (Doom et al. 2010) \\
\hline 21. Education and training for employees & (Ngai et al. 2004) \\
\hline 22. Upstream and downstream companies trust each other & (Ngai et al. 2004) \\
\hline $\begin{array}{llll}23 . & \text { Timely communication between } & \text { upstream } & \text { and } \\
\text { downstream companies } & & & \\
\end{array}$ & (Ngai et al. 2004) \\
\hline $\begin{array}{l}\text { 24. Easy communication between upstream } \\
\text { downstream companies }\end{array}$ & (Ngai et al. 2004) \\
\hline $\begin{array}{l}\text { 25. Sharing information between upstream and downstream } \\
\text { companies }\end{array}$ & (Ngai et al. 2004) \\
\hline 26. The effectiveness of traceability information & Interview \\
\hline 27. The integrity of traceability information & Interview \\
\hline 28. The authenticity of traceability information & (Xu et al. 2008)/interview \\
\hline $\begin{array}{l}\text { 29. The standardization of traceability information } \\
\text { identification }\end{array}$ & interview \\
\hline 30. Traceability system has excellent performance & (Ngai et al. 2004) \\
\hline 31. The specific function of TS satisfying users' need & (Zhang and Wei 2009)/interview \\
\hline 32. Traceability system operate easily & Interview \\
\hline
\end{tabular}




\title{
Appendix F- Participant information sheet (Chinese Version)
}

1、课题题目

\author{
参与者知情书
}

中国食品企业实施可追溯系统的关键成功因素分析

\section{2、邀请的话}

诚邀您参加此次课题。在决定是否参与之前了解课题背景和内容非常重要。如果你愿意的话, 请花时间仔细了解一下信息, 并且和别人讨论。有任何不明白的地方或者有需要了解更多信 息可以随时提问。

3、课题目标

本课题旨在识别在中国食品企业实施质量安全可追溯系统的关键成功因素, 具体来说包括总 结出追溯系统实施成功的评价标准, 识别影响系统实施成功的关键成功因素, 建立关键成功 因素框架。

4、为什么会选择我呢? 我一定要参加吗?

之所以会选择您, 因为您是实施追溯系统的食品企业的一名员工, 并且您是系统实施的负责 人 (高管) 或者实施专员。参与课题是自愿的, 您随时可以退出。

5、如果我参加会怎么安排呢?

如果您参与了, 您将接受一个半结构式访谈, 访谈主要是了解您的关于什么是实施成功和实 施的关键成功因素的理解和看法。访谈可以面对面或者通过电话。访谈时间持续大概 45 分 钟, 主要取决于您的时间是否方便和您愿意分享多少信息。我会在得到您的允许下进行访谈 记录。

6、参与访谈会有潜在的损害或者危险（对我个人或者公司）吗?

参与此次课题对个人并无影响, 得到的信息除用于此次课题研究外不会用在任何其他地方。 个人信息也不会被命名记录。

7、我的参与是被保密的吗?

在课题研究期间, 关于您的所有信息是被严格保密的。唯一要求的联系信息是电话号码或者 邮箱地址。所有访谈记录在研究结束时都将销毁。在访谈记录中不会出现您的名字或者任何 联系详情。此外, 任何有可能识别您的细节都会被删除或者改变。也不会跟其他被访人员讨 论您的情况。我不会报告任何您说的界定为非法的话。然而如果因为您参与而处于受伤害或 者危险中，您可以选择不再继续参与。

8、课题的结果是用在什么方面呢?

研究结果用于我的硕士论文。相关资料会发表在学术会议或期刊。任何时候都会匿名和保密。

9、如果有问题的话怎么办呢?

如果您愿意反馈信息或者关注此项课题的任何方面, 您可以与贝德福特大学商务与管理系的 缪美银联系来参与。记住您可以随时退出。 
详细联系信息:

缪美银, 课题研究员

电邮地址: miaomeiyin@yahoo.cn

Meiyin.Miao@beds.ac.uk

电话: 01582743138

感谢您阅读此信息知情书, 如果可能的话请参与此项课题。 


\title{
Appendix G- Interview Outline (Chinese Version)
}

\author{
访谈提纲 \\ 尊敬的先生/女士, 您好! 您在百忙之中抽出时间接受访谈, 我们不胜感激!
}

英国贝德福特大学 商务和管理系 缪美银

姓名:

职务: 工作单位:

从事信息系统实施工作的时间: 访谈时间： 记录人:

\section{一、企业实施追溯系统的概况}

1、企业员工总数是多少? 其中从事可追溯系统的实施（操作和管理）员工数为多少?

2、您的企业什么时间开始实施追溯系统？现在仍然在应用吗？系统由谁开发？

3、您认为企业为什么要实施追溯系统？（期望达成什么样的总目标？您觉得实施追溯系统 有什么意义？）

4、就您目前的情况，实施追溯系统前后，公司经济收益有否因其变化？

5、企业能追溯的产品有哪些？产品现在有销往国外吗？

6、产品的价格变化，追溯前后相差比例为多少？追溯成本包括？

7、与系统相关的操作人员的文化水平？操作前是否经过培训？遇到问题能否自己应对？

8、企业在实施追溯系统的过程中，遇到了那些困难或者问题及产生的原因？

9、您希望政府给予哪些方面的支持?

\section{二、追溯系统在食品企业的实施成功}

1、您是怎么理解追溯系统在食品企业的实施成功？

2、您认为追溯系统实施成功具体体现在那些方面？

\section{三、追溯系统在食品企业实施的关键成功因素}

1、您认为企业实施追溯系统的关键成功因素有哪些?（包括外部因素和内部因素, 及如何 理解这些因素) 


\section{Appendix H- Cover Letter (Chinese Version)}

尊敬的 先生/女士，

您好!

真诚邀请您参加一个关于追溯系统实施成功的影响因素的研究项目, 本项目旨在获得中 国食品企业实施追溯系统的关键成功因素, 为此, 我们设计了一个简短的问卷, 我衷心希望 您能够阅读并完成问卷，此份问卷会占用您约 5-10 分钟的时间。

该研究的结果将会对实施可追溯系统的食品企业有所帮助。通过您的参与, 我们希望能 够对影响追溯系统实施成功的关键因素获得更全面且深入的了解, 从而对追溯系统实施的进 一步发展做出贡献。本问卷采用匿名方式, 您的回复信息只会被用作课题研究之用, 并且完 全保密。请您认真阅读并准确选择最符合您意图的答案。答案没有对与错之分, 我们只希望 了解您的个人观点。

本问卷属于自愿参与, 但真诚的希望您能在百忙之中抽出时间来协助完成这一调查问卷。 无论您是否选择参与问卷的填写, 若您对我们的调查结果感兴趣, 请直接与我联系。如果您 对问卷的填写或者对于参与此次研究有任何问题和疑虑, 请通过以下地址与我联 系: miaomeiyin@yahoo. cn 本研究项目得到了英国贝德福德大学商学院 (University of Bedfordshire Business Schoo1）的批准, 如果您对参与此次研究的权利有任何担心, 您可 以直接与学院研究中心获得联络： yanqing. duan@beds. ac.uk

非常感谢您的参与!

缪美银

2010 年 6 月 2 日 


\section{Appendix I- Questionnaire (Chinese Version)}

\section{调查问卷}

说明:在本研究中, 追溯系统在食品企业的实施成功的评价标准主要有系统用户满意, 信息 用户满意, 食品质量和安全性提高, 企业品牌和名誉提升。关键成功因素是指对食品企业在 实施可追溯系统过程中, 对成功结果起重要影响作用的因素, 而这些因素集中代表了企业实 施系统的过程中可能遇到的问题或需要引起重点关注的领域, 对企业实施可追溯系统有重要 的指导作用。

英国贝德福特大学 商务和管理研究中心

\section{第一部分：食品企业实施质量安全可追溯系统的关键成功因素调查}

下面是根据以上定义设计的一些指标, 根据您个人对其重要程度的看法, 在相应的栏目 里画“ $`$ 。重要程度“1”为最低, “5”为最高。

\begin{tabular}{ccccc} 
不重要 & 有点重要 & 重要 & 很重要 & 极其重要 \\
\hline 1 & 2 & 3 & 4 & 5
\end{tabular}

\begin{tabular}{|c|c|c|c|c|c|c|}
\hline \multirow{2}{*}{ 编号 } & \multirow{2}{*}{ 因素 } & \multicolumn{5}{|c|}{ 重要程度 } \\
\hline & & 1 & 2 & 3 & 4 & 5 \\
\hline 1 & 完善的食品追溯规则 & & & & & \\
\hline 2 & 健全的食品追溯法律 & & & & & \\
\hline 3 & 完善的食品追溯标准 & & & & & \\
\hline 4 & 政府对企业实施追溯系统政策引导 & & & & & \\
\hline 5 & 政府对企业实施追溯系统投入资金 & & & & & \\
\hline 6 & 政府对企业实施追溯系统投入设备 & & & & & \\
\hline 7 & 政府对企业实施追溯系统技术支持 & & & & & \\
\hline 8 & 政府对消费者宣传食品追溯 & & & & & \\
\hline 9 & 消费者对可追溯食品有支付意愿 & & & & & \\
\hline 10 & 消费者对食品追溯有充分的理解 & & & & & \\
\hline 11 & 供应商在系统整个实施过程中提供持续支持 & & & & & \\
\hline 12 & 系统实施得到企业各职能部门的配合 & & & & & \\
\hline 13 & 系统运行和维护的投入 & & & & & \\
\hline 14 & 高层将实施追溯系统纳入公司战略 & & & & & \\
\hline 15 & 企业实施追溯系统有明确的目标性 & & & & & \\
\hline 16 & 高层亲身参与到追溯系统的实施 & & & & & \\
\hline 17 & 系统实施有详细缜密的安排 & & & & & \\
\hline 18 & 系统实施严格按照日程计划表执行 & & & & & \\
\hline 19 & 及时解决遇到问题 & & & & & \\
\hline
\end{tabular}




\begin{tabular}{|l|l|l|l|l|l|l|}
\hline 20 & 管理人员有责任心 & & & & & \\
\hline 21 & 员工能够接受教育和培训 & & & & & \\
\hline 22 & 上下游企业互相信任 & & & & & \\
\hline 23 & 上下游企业能够及时沟通 & & & & & \\
\hline 24 & 上下游企业容易沟通 & & & & & \\
\hline 25 & 上下游企业能够分享信息 & & & & & \\
\hline 26 & 追溯信息的有效性 & & & & & \\
\hline 27 & 追溯信息的完整性 & & & & & \\
\hline 28 & 追溯信息的真实性 & & & & & \\
\hline 29 & 追溯信息标识的标准化 & & & & & \\
\hline 30 & 追溯系统性能优 & & & & & \\
\hline 31 & 追溯系统具体的功能满足用户需求 & & & & & \\
\hline 32 & 追溯系统操作简易 & & & & \\
\hline
\end{tabular}

是否还有您认为很重要但在此问卷中没有列出的成功因素? 若有, 请填写在以下横线上

\section{第二部分：基本资料}

说明:请根据您的实际情况, 在相应选项前【】内打“『”。

1、您目前的职务
【】(1) 企业经理
【】(2) 部门经理
【】(3) 项目主管
【】(4) 经理助理
【】(5)专家
【】(6) 系统实施专员
【】(7) 系统操作员
【】(8) 其他 (请将职务填写在横线上)

2、您参加（或监督或研究）信息系统（含追溯系统）实施工作的时间
【】(1) 1 年及以内
【】(2) $2-3$ 年
【】(3) $4-6$ 年
【】(4) 7 年及以上

\section{3、您的学历}
【】(1) 初中及以下
【】(2) 高中
【】(3) 大专
【】(4) 本科及以上

4、您是否接受过在企业食品可追溯系统的相关学习或培训
【】(1) 是
【】(2) 否

最后，再次感谢您的合作和支持！

您是否需要给您邮寄此项调研报告？【】是【【】否 若选择“是”，请提供邮寄地址 


\section{Reference}

Akkermans, $\mathrm{H}$ and Helden, K V. (2002). "Vicious and Virtuous Cycles in ERP Implementation: a Case Study of Interrelations between Critical Success Factors." European Journal of Information Systems(11), 35-46.

Al-Fawaz, K., Al-Salti, Z. and Eldabi, T. (2008). "Critical Success Factors in ERP Implementation: A review." In European and Mediterranean Conference on Information Systems

Al-Mashar, M. I, Al-Mudimigh, A. and Zairi, M. (2003). "Enterprise Resource Planning: A Taxonomy of Critical Factors." European Journal of Operational Research 146(2), 352-364.

Ammendrup, S. and Barcos, L.O. (2006). "The Implementation of Traceability Systems." Rev. sci. tech. Off. int. Epiz. 25(2), 763-773.

Amoako-Gyampah, K. and Salam, A.F. (2004). "An Extension of the Technology Acceptance Model in An ERP Implementation Environment." Information and Management 41(6), 731-745.

Anthony, R. N., Dearden, J. and Vancil, R. F. (1972). Management Controls Systems. III: Irwin, Homewood.

Badiru, A. B. (1988). "Successful Initiation of Expert Systems Projects." IEEE Transactions on Engineering Management 35(3), 186-190.

Bai, Y., Lu, C. and Li, B. (2006). "Realization of Traceable System for Broiler Safe Production Monitoring." Jiangsu J. of Agr. Sci. 22(3), 281-284.

Bechini, A., Cimino, M.G.C.A., Lazzerini, B., et al. (2005). "A General Framework for Food Traceability." In Applications and the Internet Workshops(Saint Workshops 2005). Trento, 31 January-4 February.

Bhatti, T. R. (2005). "Critical Success Factor for Implementation of Enterprise Resource Planning: Empirical Validation." In The Second International Conference on Innovation in Information Technology (IIT' 05).

Bradley, J. (2008). "Management Based Critical Success Factors in the Implementation of Enterprise Resource Planning Systems." International Journal of Accounting Information Systems(9), 175-200.

Bryman, Alan. (2004). Social Research Methods. Second Edition Edition. Oxford University 
Press, Oxford.

Calof, J. and Smith, J. E. (2008). "Critical Success Factors for Government Led Foresight." In Third International Seville Seminar on Future Oriented Technology Analysis: Impacts and implications for policy and decision-making. Seville.

Caswell, J. A. (2006). "Quality Assurance, Information Tracking, and Consumer Labelling." Marine Pollution Bulletin 53, 650-656.

Ccsfa. (2007). "Phase Report of Food Safety Traceability Research." In Annual Meeting of Circulation Food Safety. Beijing: China Chain Store \& Franchise Association.

Chen, H. (2008). "GS1 System Applies in Hainan Aquatic Product Quality and Safety Traceability System." World Standardization \& Quality Management(8), 56-58.

Chen, R-S., Chen, C-C. and Yeh, K.C. (2008). "Using RFID Technology in Food Produce Traceability." WSEAS TRANSACTIONS on INFORMATION SCIENCE and APPLICATIONS 5(11), 1551-1560.

Chetcuti, H. R. . (2008). "ERP Implementation: A Multi-stakeholder Analysis of Critical Success Factors." In WICT Proceedings.

Chow, T. and Cao, D-B. (2008). "A Survey Study of Critical Success Factors in Agile Software Projects." The Journal of Systems and Software(81), 961-971.

Cimino, M.G.C.A. and Lazzerini, B. (2005). "Cerere: An Information System Supporting Traceability in the Food Supply Chain, Seventh IEEE International Conference on E-Commerce Technology Workshops."

Croteau, a-M. and Li, P. (2003). "Critical Success Factors of CRM Technological Initiatives." Canadian Journal of Administrative Sciences 20(1), 21-34.

Dan, P. K. (2009). "ERP in Indian SME's: A Post Implementation Study of the Underlying Critical Success Factors." International Journal of Management Innovation System 1(2:E1), 1-9.

Daniel, D. R. (1961). "Management Information Crisis." Harvard Business Review 39(5), 111-116.

Davenport, T.H. (1998). "Putting the Enterprise Into the Enterprise System." Harvard Business Review 76(4), 121-131.

Delone, W. H and Mclean, E. R. (1992). "Information Systems Success: The Quest for the Dependent Variable." Information Systems Research 3(1), 60-95.

Delone, W. H and Mclean, E. R. (2003). "The DeLone and McLean Model of Information Systems Success: A Ten-Year Update." Journal of Management Information Systems 19(4), 9-30. 
Dickinson, R., Ferguson, C. R and Sircar, S. (1984). "The Critical Success Factors Approach for the Design of Management Information Systems." American Business Review January, 23-28.

Doom, C., Milis, K., Poelmans, S., et al. (2010). "Critical Success Factors for ERP Implementations in Belgian SMEs." Journal of Enterprise Information Management 23(3), 378-406.

Dubelaar, C., Sohal, A. and Savic, V. (2005). "Benefits, Impediments and Critical Success Factors in B2C E-business Adoption " Technovation(25), 1251-1262.

Editor. (2004). "Vegetable Safety Traceability System Implementation in Shouguang." Journal of Changjiang Vegetables(9), 11.

Engelseth, P. (2009). "Food Product Traceability and Supply Network Integration." Journal of Business \& Industrial Marketing 24(5/6), 421-430.

Esteves, J, Sousa, Pastor, J., et al. (2000). "Towards the Unification of Critical Success Factors for ERP Implementations." In 10th Annual BIT conference. Manchester, UK.

Fang, C. and Zhao, L. (2008). "Research on Meat Food Traceability System Based on Iris-recognition." China Safety Science Journal 18(7), 11-17.

Finney, S. and Corbett, M. (2007). "ERP Implementation: A Compilation and Analysis of Critical Success Factors." Business Process Management Journal 13(3), 329-347.

Fsa. (2002). "Traceability in the Food Chain: A Preliminary Study." In Journal of Automation, Mobile Robotics \& Intelligent Systems: Food Standards Agency, March 2002, UK.

Galobardes, B., Sunyera, J. and Antóa, J. M. . (1998). "Effect of the Method of Administration, Mail or Telephone, on the Validity and Reliability of a Respiratory Health Questionnaire.The Spanish Centers of the European Asthma Study." Journal of Clinical Epidemiology 51(10), 875-881.

García-Sánchez, N. and Pérez-Bernal, L. E. (2007). "Determination of Critical Success Factors in Implementation An ERP System: A Field Study in Mexican Enterprises." Information Technology for Development 13(3), 293-309.

Giraud, G. and Halawany, R. (2006). "Consumers' Perception of Food Traceability in Europe." In The 98th EAAE Seminar 'Marketing Dynamics within the Global Trading System: New Perspectives'. Chania, Crete, Greece.

Golan, E., Krissoff, N., Kuchler, F., et al. (2004). "Traceability in the U.S. Food Supply: Economic Theory and Industry Studies." In Agricultural Economics. Washington, DC: Department of Agriculture.

Gracia, A. and Zeballos, G. (2005). "Attitudes of Retailers and Consumers toward the EU 
Traceability and Labeling System for Beef." Journal of Food Distribution Research 36(3), 45-56.

Grover, G, Jeong, S.R and Segars, A.H. (1996). "Information Systems Effectiveness: The Construct Space and Patterns of Application." Information \& Management 31(4), 177-191.

Guo, L. (2006). "Critical Success Factors for Implementing Enterprise ERP." Market Modernization 1(1), 48-49.

Hair, J. F., Anderson, R. E., Tatham, R. L., et al. (1995). Multivariate Data Analysis with Readings(4th edition). Prentice Hall College.

Han, Y. and Qiao, J. (2009). "Influence Factors on Consumers' Attitude and Willingness to Buy Traceable Foods in China: A Test and Analysis on the Survey from Beijing." Technology Economics 28(4), 37-43,53.

Holland, C. P and Light, B. (1999). "A Critical Success Factors Model For ERP Implementation." IEEE Software May/June, 30-36.

Hsu, Y-L., Li, W-C. and Chen, K-W. (2010). "Structuring Critical Success Factors of Airline Safety Management System Using A Hybrid Model." Transportation Research Part E, 222-235.

Huang, W. (2007). "Critical Success Factors for Implementing Workflow Management System in Manufacturing Enterprise Chain in Supply Chain Environment." Hanzhou City: Zhejiang University.

Ifinedo, P. and Nahar, N. (2006). "Quality, Impact and Success of ERP Systems: A Study Involving Some Firms in the Nordic-Baltic Region." Journal of Information Technology Impact 6(1), 19-46.

Jiang, D. (2007). "Success Factors Research of Information Systems in the Mechanical Manufacturers in Kunming." Hanzhou, China: Zhejiang University.

Jooken, K and Lauryssen, S. (2006). "Aquaculture and Labelling of Fish: No Fish Without Bones." Test Aankoop(496), 28-30

Karlsen, Km and Senneset, G. (2006). "Traceability: Simulated Recall of Fish Products." In Seafood Research from Fish to Dish. Quality, Safety and Processing of Wild and Farmed Fish, eds. JB Luten, C Jacobsen, K Bekaert, A Saebo and J Oehlenschlager. Wageningen: Wageningen Academic Publisher.

Kelepouris, T. (2007). "RFID-enabled Traceability in the Food Supply Chain." Industrial Management \& Data Systems 107(2), 183-200.

Kim, C. S and Peterson, D. K. (2000/2001). "Developers' Perceptions of Information Systems 
Success Factors." The Journal of Computer Information Systems, ProQuest Science Journals $41(29-35)$

Lavoie, G. and Forest, J-F. . (2009). "Implementation of a Traceability System from Constraints to Opportunities for the Industry: A Case Study of Quebec, Canada." International Food and Agribusiness Management Review 12(2), 71-79.

Lee, S. and Kim, K-J. (2007). "Factors Affecting the Implementation Success of Internet-based Information Systems." Computers in Human Behavior 23(4), 1853-1880.

Leidecker, J. K and Bruno, A. V. (1984). "Identifying and Using Critical Success Factors." Long Range Planning 17(1), 23-32.

Li, H., Fu, Z., Fu, X., et al. (2008). "Design and Realization of Vegetable Traceability System Based on Web." Jiangsu Journal of Agricultural Sciences 24(5), 716-719.

Li, X. (2006). "The Urgency and Feasibility for Establish China Aquatic Products Traceability System." China Fishery(9), 21-26.

Lin, L. and Zhou, D. (2005). "On the Construction of Food Quality and Safety Traceability System." Commercial Research(21), 41-44.

Liu, C. (2004). "Study on the Successful Key Factors of China's Enterprises ERP." Information Science 22(5), 527-529.

Loh, T.C. and Koh, S.C.L. (2004). "Critical Elements for A Successful Enterprise Resource Planning Implementation in Small-and Medium-Sized Enterprises." International Journal of Production Research 42(17), 3433-3455.

Lu, X., Huang, L. and Heng, M. S. H. (2006). "Critical Success Factors of Inter-organizational Information Systems--A Case Study of Cisco and Xiao Tong in China." Information \& Management 43(3), 395-408.

Ma, H. and Wang, S. (2006). "Traceability System for Meat Products under Food Safety Circumstance." China Safety Science Journal 16(11), 4-9.

Mallor, J. P., Barnes, A. J., Bowers, L. T., et al. (2007). Business Law: the Ethical, Global, and E-Commerce Environment (14th). The McGraw-Hill Companies, New York.

Mckean, J. D. (2001). "The Importance of Traceability for Public Health and Consumer Protection." Rev. sci. tech. Off. int. Epiz 20(2), 363-371.

Mcmeekin, T. A. and Baranyi, J. (2006). "Information Systems in Food Safety Management." International Journal of Food Microbiology 112, 181-194.

Mendel, B. (1999). "The Portal Panacea." Info World 28(31), 28-29.

Min, Q. (2005). "An Empirical Study of Critical Success Factors for Implementing Enterprise 
ERP in China." Dalian: Dalian University of Technology.

Miraglia, M. (2004). "Detection and Traceability of Genetically Modified Organisms in the Food Production Chain." Food and Chemical Toxicology(42), 1157-1180.

Motwani, J., Mirchandani, D., Madan, M., et al. (2002). "Successful Implementation of ERP Projects: Evidence from Two Case Studies." International Journal of Production Economics 75(1-2), 83-96.

Nah, F. F-H and Lau, J. L-S. (2001). "Critical Factors for Successful Implementation of Enterprise Systems." Business Process Management Journal 7(3), 285-296.

Nah, F. F-H. and Delgado, S. (2006). "Critical Success Factors for Enterprise Resource Planning Implementation and Upgrade." The Journal of Computer Information Systems, ProQuest Science Journals 46(5), 99-113.

Ngai, E.W.T., Cheng, T.C.E. and Ho, S.S.M. (2004). "Critical Success Factors of Web-based Supply-Chain Management Systems: An Exploratory Study." Production Planning \& Control 15(6), 622-630.

Nunnally, J. C. (1978). Psychometric Theory (2nd edition). McGraw-Hill, New York.

O'brien, J. A. (2002). Management Information Systems Managing Information Technology in the E-Business Enterprise(5th edition). Mc Graw Hill Irwin.

Opara, L.U. and Mazaud, F. (2001). "Food Traceability from Field to Plate." Outlook on Agric 30(4), 239-247.

Pallant, J. (2005). SPSS Survival Manual(2nd edition). Open University Press, Berkshire.

Peets, S., Gasparin, C. P., Blackburn, D. W. K., et al. (2009). "RFID Tags for Identifying and Verifying Agrochemicals in Food Traceability Systems." Precision Agric(10), 382-394.

Pinto, J. K and Slevin, D. P. (1987). "Critical Factors in Success Project Implementation." IEEE Transaction on Engineering Management 34(1), 22-27.

Rabaa'i, A. A (2009). "Identifying Critical Success Factors of ERP Systems at the Higher Education Sector." In ISIICT 2009: Third International Symposium on Innovation in Information \& Communication Technology. Philadelphia University, Amman, Jordan.

Regattieri and Gamberi, M. (2007). "Traceability of Food Products: General Framework and Experimental Evidence." Journal of Food Engineering 81, 347-356.

Remus, U. (2007). "Classification of Success Factors for Implementing Enterprise Portals-A Comparison with ERP Implementation." Business Process Management Journal 13(4), 538-552.

Ren, X., Fu, Z., Mu, W., et al. (2009). "Traceability System for Tilapia Breeding Quality Safety 
Information Based on Web." Transactions of the CSAE 25(4), 163-167.

Ren, Z. (2007). "Critical Success Factors for Implementing B2B E-business in SMEs in China." Beijing: Beijing Jiao Tong University.

Rijswijk, W. V. (2008). "Consumer Perceptions of Food Quality and Safety and Their Relation To Traceability." British Food Journal 110(10), 1034-1046.

Rockart, J. F. (1979). "Chief Executives Define Their Own Data Needs." Harvard Business Review. March-April, 81-93.

Rockart, J. F. (1982). "The Changing Role of the Information System Executive: A Critical Success Factors Perspective." Sloan Management Review 24(1), 3-13.

Rolando, A. and Stasio, L. D. (2006). "MC1R Gene Analysis Applied to Breed Traceability of Beef." Italian Journal of Animal Science 5, 87-91.

Salmeron, J. L. and Herrero, I. (2005). "An AHP-based Methodology to Rank Critical Success Factors of Executive Information Systems." Computer Standards \& Interfaces 28(1), 1-12.

Sarivougioukas, J.C. and Vagelatos, A. T. (2002). "Determination of the Success of A Hospital's Information System Implementation " In Proceedings of EMBEC. Viena, Austria.

Saunders, M., Lewis, P. and Thornhill, A. (2009). Research Methods for Business Students. the fifth edition Edition. Pearson Education Limited, UK.

Schwagele, F. (2005). "Traceability from A European Perspective." Meat Science 71(1), 164-173.

Sekaran, U. (2003). Research Methods for Business---a Skill Building Approach. Southern Illionois University at Carbondale, John Wiley \& Sons, Inc.

Shackell, G.H. and Dodds, K.G. (2008). "DNA-Based Traceability of Meat." In Meat Biotechnology. Springer New York.

Shanksa, Graeme. (2000). "A model of ERP project implementation." Journal of Information Technology 15(4), 289 - 303.

Shao, Z. and Lin, H. (2006). "Significances and Measures of Firms Implementing Seafood Traceability Systems." Chinese Fisheries Economics(3), 46-49.

Sioen, I, Verbeke, W, De Henauw, S, et al. (2007). "Determining the Origin of Seafood Products on the Belgian Market: Challenges to Traceability and Database Management." The Open Food Science Journal(1), 33-42.

Skoglund, T. and Dejmek, P. (2007). "Fuzzy Traceability: A Process Simulation Derived 
Extension of The Traceability Concept in Continuous Food Processing." Trans IChemE, Part C,Food and Bioproducts Processing 85(C4), 354-359.

Soja, P. (2006). "Success Factors in ERP Systems Implementations: Lessons from Practice." Journal of Enterprise Information Management 19(4), 418-433.

Somers, T. M and Nelson, K. G. (2004). "A Taxonomy of Players and Activities Across the ERP Project Life Cycle " Information \& Management 41(3), 257-278

Souza-Monteiro, D. M. and Caswell., J. A. (2004). "The Economics of Implementing Traceability in Beef Supply Chains: Trends in Major Producing and Trading Countries." In Department of Resource Economics Working Paper,No 2004-6: University of Massachusetts-Amherst, US.

Sumner, M. (1999). "Critical Success Factors in Enterprise Wide Information Management Systems Projects." In Proceedings of the 1999 ACM SIGCPR Conference on Computer Personnel Research. Milwaukee: ACM, 232-234.

Sun, Y., Huang, Q. and Zhang, C. (2007). "The Empirical Study of Critical Success Factors of ERP Implementation." Journal of Chongqing University(Social Science Edition) 13(4), 39-43.

Szewczyk, R., Rzeplińska-Rykała, K., Winiarski, W., et al. (2008). "Application of the Industrial Automation Standards and Methodologies for Reliable and Continous European Food Traceability System." Journal of Automation, Mobile Robotics \& Intelligent Systems 2(3), 55-57.

Tabachnick, B. G. and Fidell, L. S. (2001). Using Multivariate Statistics (4th edition). Pearson Education.

Tao, Z. and Wang, Y. (2006). "Establishment of Beijing Vegetable Quality and Safety Traceability System." China Vegetables(8), 1-3.

Thakur, M. and Hurburgh, C. R. (2009). "Framework for Implementing Traceability System in the Bulk Grain Supply Chain." Journal of Food Engineering(95), 617-626.

Umblea, E. J, Haft, R. R and Umble, M. M. . (2003). "Enterprise Resource Planning: Implementation Procedures and Critical Success Factors " European Journal of Operational Research 146(2), 241-257.

Verbeke, W. and Ward, R. W. (2006). "Consumer Interest in Information Cues Denoting Quality, Traceability and Origin: An Application of Ordered Probit Models to Beef Labels." Food Quality and Preference(15), 453-467.

Verbeke, W., Ward, R. W. and Avermaete, T. (2002). "Evaluation of Publicity Measures Relating to the EU Beef Labeling System in Belgium." Food Policy 27(5), 339-353. 
Verbeke, W. and Ward, R.W. (2003). "Importance of EU Label Requirements: an Application of Ordered Probit Models to Belgium Beef Labels." In Paper presented at the American Agricultural Economics Association Annual Meeting. Montreal, Canada, July 27-30.

Williams, J. J and Ramaprasad, A. (1998). "The Utilization of Critical Success Factors: A Profile." In Proceedings of the 29th annual meeting of the Decision Sciences: Decision Sciences Institute.

Wong, K. Y. (2005). "Critical Success Factors for Implementing Knowledge Management in Small And Medium Enterprises " Industrial Management \& Data Systems 105(3), 261-279.

Wu, D., Lu, C. and Cheng, H. (2009). "Recent Developments of Food Safety Traceability System and its Perspective on Tea." Chinese Agricultural Science Bulletin 25(1), 251-255.

Xiao, L. (2004). "General Administration of Quality Supervision, Inspection and Quarantine promulgates 'Exit Aquatic Product Traceability Procedure' and 'Exit Aquaculture Products Inspection and Quarantine and Regulatory Requirements' " China Fisheries(10), 5.

Xie, J. (2005). "Pork Safety Production Traceability System." Beijing: China Agricultural University.

Xie, J., Lu, C., Li, B., et al. (2006). "Implementation of Pork Traceability System Based on.NET Framwork." Transactions of the CSAE 22(6), 218-220.

Xu, J., Deng, H. and Zhou, H. (2008). "Analyze Institution Building of Agricultural Products Quality and Safety Traceability." Journal of Hunan Agricultural University (Social Sciences) 9(2), 24-28.

Xu, L. and Wu, L. (2008). "Research of Consumer Behavior in Food Traceability System: A Literature Review." Consumer Economics 24(5), 93-97.

Yang, L. (2005). "EAN UCC System Application to Establish the Eel Quality of Tracking and Tracing System." World Standardization \& Quality Management(3), 43-44.

Yang, L. (2007). "The Design and Realization of Breed Tache in the System of Pork Quality Safe Traceability." Agriculture Network Information(12), 42-44.

Yang, L., Luo, Q. and Xiong, B. (2008a). "The Design and Realization of Slaughter Tache in the System of Pork Quality Safe Traceability." Agriculture Network Information(1), 22-25.

Yang, X., Sun, C. and Qian, J. (2008b). "Construction and Implementation of Fishery Product Quality Traceability System Based on the Flow Code of Aquaculture." Transactions of the CSAE 24(2), 159-164. 
Yeoh, W., Gao, J. and Koronios, A. (2007). "IFIP International Federation for Information Processing, Volume 255." In Research and Practical Issues of Enterprise Information Systems Volume 2, eds. LXu, A Tjoa and S Chaudhry, (Boston:Springer).

Yin, J., Tao, Y. and Liu, T. (2008). "First Exploration of Construction of Food Traceability System " Journal of Anhui Agri.Sci. 36(27), 11985-11987,11994.

Zan, L., Zhen, T., Ma, S., et al. (2006). "Studies and Application of Beef Safety Traceability Information Management System." Chinese Agricultural Science Bulletin 22(8), 22-25.

Zan, M., Zhang, Y., Han, K., et al. (2007). "Application of RFID-technique in Traceability System for Livestock Products." Meat Research(9), 32-35.

Zen, Y. (2005). "Barcode Vegetables Explore the Road of Quality and Safety Traceability in China." Vegetables(10), 1-4.

Zeng, W. and Huang, B. (2005). "Reliability and Validity Analysis of Questionnaire." Statistics and Information Forum(6).

Zhai, L., Hua, P. and Hu, R. (2008). "Structure Equation Modeling of Critical Success Factors for IS/IT Projects." Journal of Systems Engineering 23(3), 352-356.

Zhang, B., Huang, Z. and Ye, C. (2007). "Design and Implement of Vegetable Quality and Safety Traceability System." Food Science 28(8), 573-577.

Zhang, L., Lee, M. K.O., Zhang, Z., et al. (2002). "Critical Success Factors of Enterprise Resource Planning Systems Implementation Success in China." In Proceedings of the 36th Hawaii International Conference on System Sciences(HIC'03) IEEE.

Zhang, L. and Wei, D. (2009). "Animal Identification and Problems and Suggestions for Traceability System Implementation." Chinese Journal of Animal Health Inspection 26(6), 20-21.

Zhang, Z., Lee, M. K.O., Huang, P., et al. (2005). "A Framework of ERP Systems Implementation Success in China: An Empirical Study." International Journal of Production Economics(98), 56-80.

Zhao, M. and Liu, X. (2007). "Construction and Practice of Vegetable Quality and Safety Traceability System " China Vegetables(7), 1-3.

Zhou, J. and Jiang, L. (2007). "An Analysis on Vegetable Farmers' Behaviors and the Food Safety System." Journal of Zhejiang University (Humanities and Social Sciences) 37(2), 118-126.

Zhu, X. (2008). "Promote Quality and Safety Traceability System to Ensure Vegetables Consumption Safety." Vegetables(7), 34-35. 


\section{DECLARATION}

I declare that this thesis is my own unaided work. It is being submitted for the degree of Master of Science by research at the University of Bedfordshire.

It has not been submitted before for any degree or examination in any other University.

Name of candidate: Meiyin Miao Signature:

Date: 